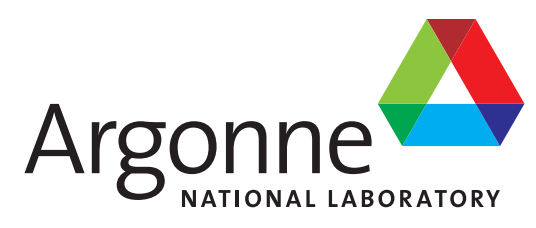

ANL/ESD-13/12

\title{
Analysis of Riverine Sediment and Nutrient Exports in Missouri River Basin by Application of SWAT Model
}

Energy Systems Division 


\begin{abstract}
About Argonne National Laboratory
Argonne is a U.S. Department of Energy laboratory managed by UChicago Argonne, LLC under contract DE-AC02-06CH11357. The Laboratory's main facility is outside Chicago, at 9700 South Cass Avenue, Argonne, Illinois 60439. For information about Argonne and its pioneering science and technology programs, see www.anl.gov.
\end{abstract}

\title{
DOCUMENT AVAILABILITY
}

Online Access: U.S. Department of Energy (DOE) reports produced after 1991 and a growing number of pre-1991 documents are available free via DOE's SciTech Connect (http://www.osti.gov/scitech/)

Reports not in digital format may be purchased by the public from the National Technical Information Service (NTIS):

U.S. Department of Commerce

National Technical Information Service

5301 Shawnee Rd

Alexandra, VA 22312

www.ntis.gov

Phone: (800) 553-NTIS (6847) or (703) 605-6000

Fax: (703) 605-6900

Email: orders@ntis.gov

Reports not in digital format are available to DOE and DOE contractors from the Office of Scientific and Technical Information (OSTI):

U.S. Department of Energy

Office of Scientific and Technical Information

P.O. Box 62

Oak Ridge, TN 37831-0062

www.osti.gov

Phone: (865) 576-8401

Fax: (865) 576-5728

Email: reports@osti.gov

\footnotetext{
Disclaimer

This report was prepared as an account of work sponsored by an agency of the United States Government. Neither the United States Government nor any agency thereof, nor UChicago Argonne, LLC, nor any of their employees or officers, makes any warranty, express or implied, or assumes any legal liability or responsibility for the accuracy, completeness, or usefulness of any information, apparatus, product, or process disclosed, or represents that its use would not infringe privately owned rights. Reference herein to any specific commercial product, process, or service by trade name, trademark, manufacturer, or otherwise, does not necessarily constitute or imply its endorsement, recommendation, or favoring by the United States Government or any agency thereof. The views and opinions of document authors expressed herein do not necessarily state or reflect those of the United States Government or any agency thereof, Argonne National Laboratory, or UChicago Argonne, LLC.
} 


\section{Analysis of Riverine Sediment and Nutrient Exports in Missouri River Basin by Application of SWAT Model}

by

Zhonglong Zhang

U.S. Army Engineer Research and Development Center, Environmental Laboratory, Badger Technical Services

May Wu

Energy Systems Division, Argonne National Laboratory

October 2013 



\section{CONTENTS}

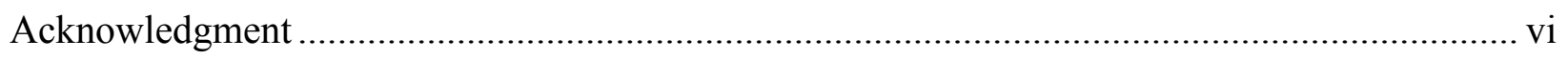

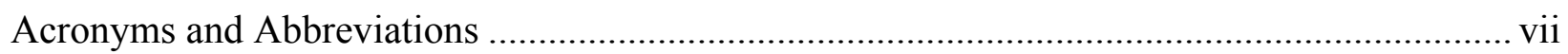

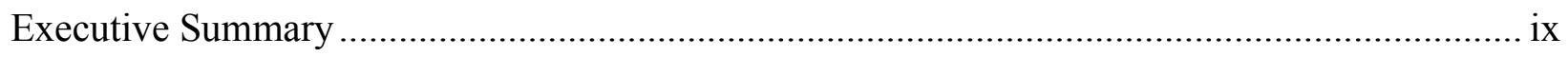

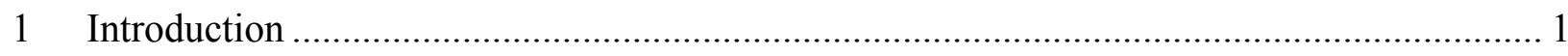

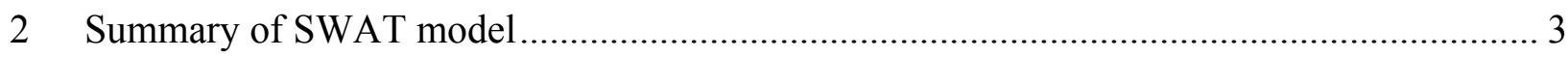

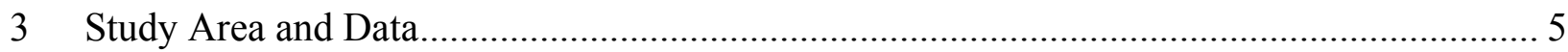

4 Model Development, Calibration and Validation …………………................................. 9

4.1 Model Setup and Parameterization..................................................................... 9

4.2 Model Calibration and Validation ...................................................................... 13

$5 \quad$ Base Model Calibration and Validation Results ............................................................... 16

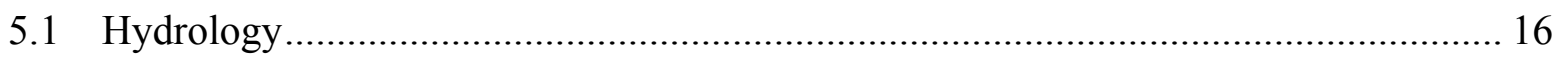

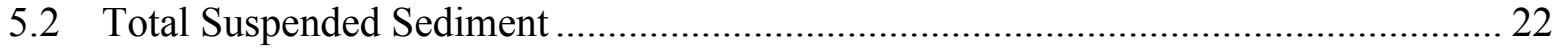

5.3 Nitrogen and Phosphorus ....................................................................................... 25

6 Analysis of Riverine Sediment and Nutrient Exports from MORB Tributaries ................... 27

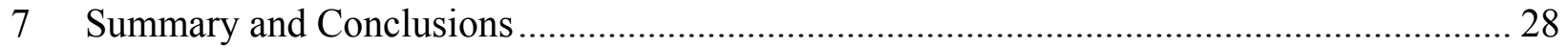

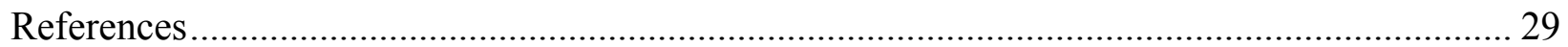

Appendix A Observed and Modeled Time Series Plots of Annual and Monthly Averaged Flow for Nineteen Stations in the Missouri River Basin ...............................................................33

Appendix B Observed and Modeled Time Series Plots of Annual (Water Year) and Monthly Total Suspended Sediment for Ten Stations in the Missouri River Basin ......................55

Appendix C Observed and Modeled Time Series Plots of Monthly Total Nitrogen and Phosphorous for Seven Stations in the Missouri River Basin

Appendix D Modeled Annual Averaged (2006-2008) Results for Each Sub-basin in the Missouri River Basin

Appendix E Water Quality Results, Land Use, and Fertilizer Application Rates at Sub-basin Scale. 


\section{FIGURES}

1 Nitrogen and phosphorus cycles modeled by SWAT ..................................................... 5

2 Location of the MORB and its major sub-basins and tributaries ........................................ 6

3 8-Digit hydrologic units and major point source locations in the MORB ............................. 8

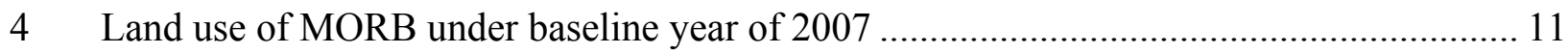

5 Percent of tillage practices under CT, RT, NT for corn in the MORB baseline year.......... 12

$6 \quad$ Percent of tillage practices under CT, RT, NT for soybeans ........................................... 12

7 Locations of USGS stream flow gage stations in the MORB............................................. 14

8 Time series plots of observed and modeled annual and monthly mean stream flow over the calibration and validation time periods at the outlet of UMORB ........................... 19

9 Time series plots of observed and modeled annual and monthly mean stream flow over the calibration and validation periods for the gage at LMORB outlet ........................ 20

10 Scatter plots of monthly observed stream flow versus monthly simulated/observed stream flow ratio for the calibration and validation period for the outlet of UMORB and LMORB

11 Observed and simulated monthly stream flow duration curves for the model calibration and validation time period

12 Time series plots of observed and modeled annual and monthly riverine total suspended sediment loads of a monitoring gage over the calibration and validation periods.

13 Time series plots of observed and modeled annual and monthly riverine total suspended sediment loads of a monitoring gage over the calibration and validation periods. 25

14 Time series plots of observed and modeled monthly riverine TN and TP loads over

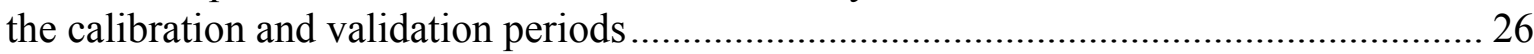

15 Simulated annual mean riverine sediment and nutrient loads for the period 2006-2008 28

D.1 Net amount of water that leaves the sub-basin and contributes to stream flow................... 76

D.2 Sediment yield transported from each sub-basin into the reach .......................................... 77

D.3 Total Nitrogen yield transported from each sub-basin into the reach................................... 78

D.4 Total Phosphorous yield transported from each sub-basin into the reach ........................... 79 


\section{TABLES}

$1 \quad$ MORB data used in the SWAT model and their sources. ............................................... 7

2 Missouri river main stem dams and reservoirs. ......................................................... 9

3 List of major crops and rotational classes............................................................ 10

4 Hydrology calibration results for each stream flow gage station. ................................... 17

5 Hydrology validation results for each stream flow gage station....................................... 18

6 Annual sediment calibration and validation results for selected stream flow gages. .......... 23

7 Monthly sediment calibration and validation results for selected stream flow gages. ........ 23

8 Summary of riverine sediment and nutrient export loads........................................... 27

E.1 Water yield, flow, total nitrogen and total phosphorus loadings. .................................. 81

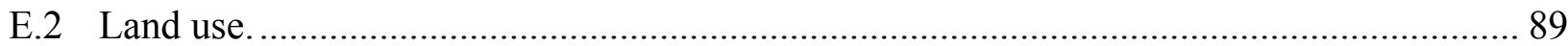

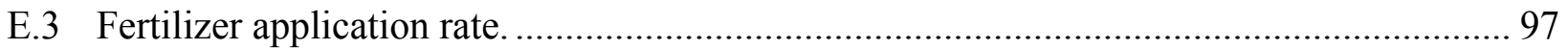




\section{ACKNOWLEDGMENT}

This work is supported by the United State Department of Energy, Office of Energy

Efficiency and Renewable Energy, Bioenergy Technology Office under Contract No. DE-AC0206CH11357. The authors would like to thank Yi-wen Chiu of Argonne National Laboratory for collecting and processing agricultural datasets. 


\section{ACRONYMS AND ABBREVIATIONS}

\begin{tabular}{|c|c|}
\hline ARS & U.S. Department of Agriculture Agricultural research service \\
\hline CDL & Cropland Data Layer \\
\hline CT & Conventional Tillage \\
\hline CTIC & Conservation Technology Information Center \\
\hline DEM & Digital Elevation Model \\
\hline HRU & Hydrological Response Units \\
\hline HUC8 & 8-digit Hydrologic Unit Watersheds \\
\hline LMORB & Lower Missouri River Basin \\
\hline Manning's N & Empirical coefficient used in Manning's formulation to compute flow discharge \\
\hline MORB & Missouri River Basin \\
\hline NASS & National Agricultural Statistic Service \\
\hline NCDC & National Climate Data Center \\
\hline NH4 & Ammonium \\
\hline NH4-N & Ammonia Nitrogen \\
\hline NID & National Inventory of Dams \\
\hline $\mathrm{NO} 2-\mathrm{N}$ & Nitrite Nitrogen \\
\hline NO3 & Nitrate \\
\hline NO3-N & Nitrate Nitrogen \\
\hline NSE & Nashe-Sutcliffe Efficiency \\
\hline NT & No-Tillage \\
\hline OTRB & Ohio-Tennessee River Basin \\
\hline PBIAS & Percent bias \\
\hline PCS & Permit Compliance System \\
\hline RF1 & USEPA Stream Network Data \\
\hline RMSE & Root Mean Square Error \\
\hline RSR & Ratio of RMSE to standard deviation \\
\hline RT & Reduced Tillage \\
\hline SCS & Soil Conservation Service \\
\hline STATSGO & State Soil Geographic Data Base \\
\hline SWAT & Soil Water Analysis Tool \\
\hline $\mathrm{TN}$ & Total Nitrogen \\
\hline TP & Total Phosphorus \\
\hline
\end{tabular}




$\begin{array}{ll}\text { UMoRB } & \text { Upper Missouri River Basin } \\ \text { UMRB } & \text { Upper Mississippi River Basin } \\ \text { USACE } & \text { U.S. Army Corps of Engineers } \\ \text { USEPA } & \text { U.S. Environmental Protection Agency } \\ \text { USGS } & \text { U.S. Geological Survey }\end{array}$




\section{EXECUTIVE SUMMARY}

The U.S. Department of Energy's Bioenergy Technology Office has set a goal of developing the resources, technologies, and systems needed to grow a biofuels industry in a way that is economically feasible, socially responsible, and environmentally sustainable (US DOE, 2011). Environmental sustainability emphasizes maintaining the services provided by natural resources - one of the critical components to a sustainable bioenergy industry. Among the natural resources, water use and water quality are key factors that intrinsically link to energy and fuel production across its supply chain and are affected by climate change. In the context of water quality, the delivery of large volumes of nutrients from the Mississippi River to the Gulf of Mexico is a significant national concern. Given the importance of the Mississippi River Basin (MRB) and its role in large-scale biofuel feedstock production, there is an urgent need to examine the interactions between biofuel feedstock production and water quality at a regional scale. Simulations of changes in water quality in response to future scenarios could provide valuable regional-specific information to assist decision makers in project planning and site selection.

With the support from Bioenergy Technology Office, a multi-institute watershed simulation effort that focuses on the tributaries of the Mississippi River Basin was initiated in 2009. The study used the Soil and Water Assessment Tool (SWAT) - a public domain watershed model developed by the U.S. Department of Agriculture Agricultural research Service (ARS) - to identify major nonpoint sources, predict riverine sediment and nutrient exports, and track their delivery to the Mississippi River. As a part of the larger study, this report focuses on modeling and analysis of riverine sediment and nutrient loads associated with the Missouri River Basin (MORB). A SWAT model was calibrated and validated with 20 years of measured stream flow data collected from 20 U.S. Geological Survey stream flow gage stations for watershed hydrology. The calibration of riverine sediment and nutrient load was based on a subset of the locations used in the calibration of hydrology with limited measured data. SWAT model parameterization and evaluation are presented, along with the decisions made to overcome problems related to data representation in the basin. Model performance ranges from satisfactory to very good for both calibration and validation periods. Results for the riverine sediment and nutrient loads indicate a need for an increase in measured data, as well as more refined model discretion.

Further analysis revealed considerable variation in loads and yields of sediment, total nitrogen, and total phosphorus among the major tributaries of the MORB. The largest total nitrogen and total phosphorus loads were in the Lower Missouri River sub-basin and Middle Missouri River sub-basin. The smallest loads were from the Upper Missouri and Yellowstone River sub-basins, where inputs from all sources are modest and attributable to the large pasture and range land in this area. The total load delivered to the Mississippi River from the MORB included approximately $6.1 \times 10^{7}$ tons $/ \mathrm{yr}$ of total suspended sediment, $4.5 \times 10^{8} \mathrm{~kg} / \mathrm{yr}$ of total nitrogen, and $1.0 \times 10^{8} \mathrm{~kg} / \mathrm{yr}$ of total phosphorus. Of these loads, Middle Missouri and Lower Missouri River sub-basins contribute $28.4 \%$ and $29.1 \%$ of the nitrogen, respectively, and $18.6 \%$ and $38.7 \%$ of the phosphorus, respectively; however, the nitrogen and phosphorus contributions by the Upper Missouri and Yellowstone sub-basins were less than $0.4 \%$. In terms of total 
suspended sediments load, the Lower Missouri sub-basin has the largest share and Upper Missouri and Kansas sub-basins the smallest.

The study shows that SWAT can be used to adequately estimate stream flow and riverine sediment and nutrient loads throughout the MORB, especially at the monthly increments. The most critical areas of sediment and nutrient losses to riverine systems can be adequately identified. With additional parameterization with respect to land use change and management, the model is able to evaluate the impact that new crop production, implementation of land management practices, and climate changes could have on the MORB - information that could aid in the selection and placement of suitable agricultural practices and in the choice landscape management strategies for cost-effective reductions in sediment and nutrient pollution. This evaluation is particularly valuable in biofuel feedstock cultivation in the river basin. We have confidence that the SWAT model will be useful for future studies in this region to predict changes in average sediment and nutrient loads in response to increased biofuel feedstock production under various future scenarios. 


\title{
Analysis of Riverine Sediment and Nutrient Exports in Missouri River Basin by Application of SWAT Model
}

\author{
Zhonglong Zhang ${ }^{1}$, May $\mathrm{Wu}^{2}$ \\ 1 US Army Corps of Engineers, Engineer Research and Development Center - \\ Environmental Laboratory, Vicksburg, MS, USA \\ 2 Argonne National Laboratory, Energy Systems Division, Lemont IL, USA
}

\section{INTRODUCTION}

Nutrient enrichment has been identified by U.S. Environmental Protection Agency (USEPA) as one of the leading causes of water quality impairment in rivers, lakes, and estuaries (USEPA, 2009). Losses of the major nutrients, nitrogen $(\mathrm{N})$ and phosphorus $(\mathrm{P})$, from agricultural lands to water bodies cause water quality concerns relative to the health of both humans and aquatic systems, and impair water resource uses. Soil erosion that moves sediments, and sediment-bound nutrients into waterways is another factor influencing water quality. There is a strong correlation between suspended sediment and total phosphorus concentrations (Wetzel, 2001). In the Missouri River Basin (MORB), more than 160 stream reaches, lakes or reservoirs, and points were reported to the USEPA for nutrient-related impairment on the 2006 303(d) lists (USEPA Water Quality Assessment and Total Maximum Daily Loads Information, http://www.epa.gov/waters/ir/). The Missouri River had the largest sediment loads of any large river in the United States and contributed nearly one-half the sediment delivered to the Gulf of Mexico by the Mississippi River (Meade, 1995). In addition, nutrient loading from the MORB and other major tributary basins of the Mississippi River has been linked to hypoxic conditions in the northern Gulf of Mexico (Rabalais et al., 2002; Donner and Scavia, 2007; Scavia and Donnelly, 2007; Turner et al., 2008). Across the nation, nutrient concentrations in all measured watersheds increased between 1940 and 1980 compared to baseline levels [22], but since then the changes have been minimal.

Historically, in streams, nutrient inputs to the MORB come from several sources, including agricultural, livestock, municipal wastewater treatment plants (WWTPs), and industries. To support crop growth, chemical fertilizers are supplied, although the application rate varies considerably from place to place within the basin. Throughout the region, the amount of nitrogen applied increased rapidly beginning in 1964, until it reached a plateau in 1976. Since 1980, the application of nitrogen fertilizer has remained relatively stable, and has even decreased, as have inputs from manure and nitrogen from atmospheric deposition.

Another key source of nitrogen and phosphorus is manure produced from livestock operation. In the United States, about $5 \%$ of all croplands are fertilized with livestock manure (USDA ERS 2009). Within a cropland, corn accounts for over half the acreage to which manure is applied. In recent years, livestock production has shifted to concentrated animal operation facilities, which generate large quantities of manure in limited geographic areas. When the 
aggregated manure from these operations exceeds the local crop nutrient requirement, excess nutrients from the manure can lead to water pollution.

The hypoxic zone in the Gulf is one of the largest in the world and its size is related to the fluxes of nutrients from the Mississippi River (Rabalais et al., 2002). In 2008, led by the USEPA, The Mississippi River/Gulf of Mexico Watershed Nutrient Task Force - Hypoxia Task Force (HTF) began to develop a plan to reducing nutrient export by the Mississippi and Atchafalaya Rivers. It was suggested that nitrogen export may need to be reduced by up to $55 \%$ to achieve the hypoxia-reduction goal because of annual climate-driven variability in nitrogen flux and annual variability in ocean dynamics (Donner and Scavia, 2007; Scavia and Donnelly, 2007). The HTF set a goal of $50 \%$ reduction of nutrient in the watersheds of the 12 Mississippi River basin states (USEPA 2008). A five-year re-assessment in 2013 has already shown promising results in several states (USEPA 2013). Therefore, the ability to estimate stream flow, sediment and nutrient loading at any point on a river throughout the MORB can further provide valuable information for quantifying the effect of water resource management.

This study focuses on the use of the Soil and Water Assessment Tool (SWAT) for making such estimates while utilizing typical data available at the national level and evaluating riverine sediment and nutrient exports. The SWAT model was chosen because of its capability of assessing the impact of land management and climate patterns on water, sediment, and nutrient yields over long periods in large watersheds and from an agricultural perspective. Furthermore, in earlier studies, SWAT has been successfully applied over a wide range of scales including the Upper Mississippi River Basin (UMRB) and the Ohio-Tennessee River Basin (OTRB).

We focused on the MORB because it is the largest U.S. watershed of the Mississippi River and because of its role in large-scale biofuel feedstock production (Wu et al. 2012; Demissie et al. 2012). The long-term implications of land use change and land management and practices on water quality compare with a baseline at river basin scale has not been fully understood, therefore warrant an investigation. Even though cultivated cropland is not the dominant land cover in the MORB, the amount of cultivated cropland is about equal to that of cultivated cropland in the UMRB and the OTRB combined. Compared to other sub-basins like UMRB and OTRB, the whole MORB has not been modeled, including an assessment of how potential land management practices and weather changes could influence riverine sediment and nutrient exports in this region. SWAT has previously been used to model various physical and biogeochemical processes and predict the riverine sediment and nutrient exports in the UMRB and OTRB. SWAT is considered suitable for simulating the long-term impacts of land management practices and weather changes on water, sediment, and nutrient loss from large, complex watersheds (Arnold et al., 1998; Gassman et al., 2007; Arabi et al., 2008; Sahu and Gu, 2009). Many studies have used SWAT because of its physical representation capabilities in conjunction with varied management options. However, improving SWAT model predictions for a large river basin under data limitations is still a great challenge, in the context of providing realistic riverine sediment and nutrient predictions. Especially for sediments and nutrients, only a few grab samples per year and only for a few years are often available. Moreover, it is usual that available observed data in a large river basin come from different stations without time overlap, thus evaluation of riverine sediment and nutrient model predictions must often be conducted for different periods and locations across the basin under different scenarios. 
This study is a long-term, detailed analysis of riverine sediment, nitrogen and phosphorus loads for the MORB using SWAT. Our approach is to fully calibrate and evaluate the model to 20 years of observations for stream flows, riverine sediment and nutrient loads if observed data are available. The other main objective of this study is to investigate potential factors controlling riverine sediment and nutrient exports as part of an investigation of the large-scale biofuel feedstock production impacts on water quality. The SWAT model was used to explore the role of land use, management practices and weather changes on sediment and nutrient loading and explore potential reasons for the increased riverine sediment and nutrient loads - key parameters considered include (1) land use changes; (2) changes in in fertilizer application rates and tillage practices; and (3) changes in rainfall patterns. The results from this study are expected to aid in predicting the potential impacts of projected changes in land use, management practice and weather, especially in regard to a shift toward biofuel feedstock production. It is our hope that this study will result in a further understanding of nutrient transport and fate in the MORB - that understanding is critical to designing and implementing the right management practices to effectively reduce nutrient losses into waterways.

\section{SUMMARY OF SWAT MODEL}

SWAT is a public domain watershed model developed by the U.S. Department of Agriculture Agricultural research Service (ARS). The details of SWAT model used are kept to a minimum here because it is well-documented elsewhere in the peer-reviewed scientific literatures (e.g., Arnold et al., 1998, Neitsch et al., 2011). In SWAT the watershed is delineated into a number of sub-basins based on topography. Each sub-basin possesses a geographic position in the watershed and is spatially related to adjacent sub-basins. Each sub-basin is further divided into hydrological response units (HRUs) based on land use, soil and slope classes. HRUs are the smallest computational units in SWAT with unique land use, soil type and slope within a sub-basin. Thus, SWAT can take two levels of the spatial heterogeneity into account. The first level (sub-basin) supports the spatial heterogeneity associated with hydrology, and the second level (HRU) incorporates the spatial heterogeneity associated with land use, soil type and slope class. Within a sub-basin, SWAT does not retain the spatial location of each HRU. Hydrologic, soil, water quality and other processes are modeled within the sub-basins through the use of HRUs. Flow generation, sediment yield, and pollutant loadings are summed across all HRUs in a sub-basin, and the resulting flow and loads are then routed through channels, ponds, and/or reservoirs to the watershed outlet. All model calculations are performed on a daily time step.

Major model components include climate, hydrology, erosion and sedimentation, nutrient cycle, plant growth, and land management. For climate, SWAT uses the data from the station nearest to the centroid of each sub-basin. The hydrological model is based on the water balance equation in the soil profile, where the processes simulated include surface runoff/infiltration, evapotranspiration, lateral flow, percolation, and return flow. SWAT considers a shallow unconfined aquifer, which contributes to the return flow and a deep confined aquifer acting as a source or sink. Surface runoff volume and infiltration are computed by using the modified SCS curve number method or Green and Ampt equation. The peak rate component uses Manning's formula to determine the watershed time of concentration and considers both 
overland and channel flow. Groundwater flow contribution to total stream flow is simulated by routing a shallow aquifer storage component to the stream (Arnold and Allen, 1996). Channel routing is simulated by using either the variable-storage method or the Muskingum method; both methods are variations of the kinematic wave model.

Erosion and sediment yield are estimated for each HRU with the Modified Universal Soil Loss Equation (Williams and Berndt, 1977). The SWAT model also calculates the contribution of sediment to channel flow from lateral and groundwater sources. The channel sediment routing uses a modification of Bagnold's sediment transport equation (Bagnold, 1977) that estimates the transport concentration capacity as a function of velocity. The model either deposits excess sediment or re-entrains sediment through channel erosion depending on the sediment load entering the channel. The delivery ratio is estimated for each particle size as a linear function of fall velocity, travel time, and flow depth.

SWAT simulates the transformation and movement of nitrogen and phosphorus in several organic and inorganic pools (Fig. 1). The soil nitrogen cycle is simulated by using five different pools; two are inorganic forms (ammonium and nitrate) while the other three are organic forms (fresh, stable, and active). The SWAT model simulates movement between N pools, such as mineralization, decomposition and immobilization, nitrification, denitrification, and ammonia volatilization. Other soil $\mathrm{N}$ processes - such as plant uptake, N fixation by legumes and NO3-N movement in water - are also included in the model. Nitrates are removed from soil with surface and subsurface runoff, while the amount of organic $\mathrm{N}$ transported with sediments is calculated as a function of organic $\mathrm{N}$ in the top soil layer and the sediment yield. The loading function estimates daily organic nitrogen runoff loss on the basis of the concentrations of constituents in the top soil layer, the sediment yield, and an enrichment ratio. Nitrate export with runoff, lateral flow, and percolation are estimated as products of the volume of water and the average concentration of nitrate in the soil layer. Once $\mathrm{N}$ enters channel flow, the SWAT model partitions $\mathrm{N}$ into four pools: organic N, NH4-N, nitrite-N (NO2-N), and NO3-N. The SWAT model simulates changes in $\mathrm{N}$ that result in movement of $\mathrm{N}$ between pools. SWAT simulates six different pools of phosphorus in soil; three are inorganic forms and the rest are organic forms. Transformations of soil $\mathrm{P}$ among these six pools are regulated by algorithms that represent mineralization, decomposition, and immobilization. The solution (labile) pool is considered to be in rapid equilibrium (days to weeks) with active pools that subsequently are considered to be in slow equilibrium with stable pools. The amount of soluble $\mathrm{P}$ removed in runoff is predicted by using labile $\mathrm{P}$ concentration in the top soil layer, the runoff volume and a phosphorus soilpartitioning factor. Sediment transport of $\mathrm{P}$ is simulated with a loading function similar to the organic $\mathrm{N}$ transport. In-stream $\mathrm{P}$ dynamics in SWAT are also simulated by using two state variables as inorganic and organic P adopted from the QUAL2E model (Brown and Barnwell, 1987). 


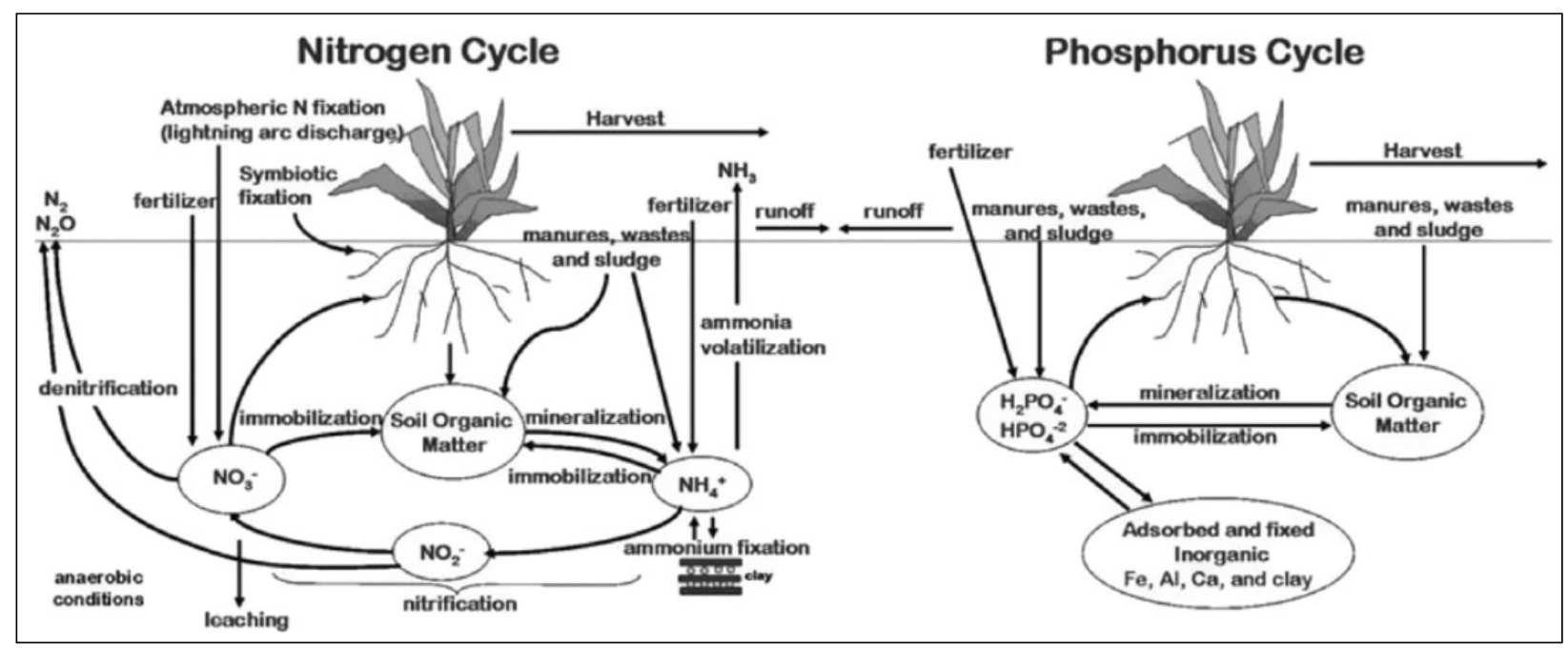

FIGURE 1 Nitrogen and phosphorus cycles modeled by SWAT (Neitsch et al., 2011).

Vegetation growth is dynamically simulated with a heat unit phenological development method. Crop yield is determined from the biomass at harvest and the harvest index. Plant growth is limited by temperature, water, and nutrient deficiencies; and is influenced by agricultural management (e.g., fertilization, irrigation, and timing of operations). SWAT utilizes routines for computing plant development on the basis of plant-specific input parameters included in the plant growth database.

\section{STUDY AREA AND DATA}

The focus of this study is on the MORB. The MORB is the largest of the water resource regions that make up the Mississippi River Basin. The basin drains about 1,502,000 $\mathrm{km}^{2}$, onesixth of the conterminous United States, and is located in parts of 10 States and Canada (Fig. 2). The Missouri River is the longest river in the U.S. The main stem of the Missouri River flows $3,768 \mathrm{~km}$ from Three Forks, Montana to its confluence with the Mississippi River near St. Louis, Missouri, which eventually flows to the Gulf of Mexico. The Missouri's largest tributaries by runoff are the Yellowstone in Montana and Wyoming, the Platte in Wyoming, Colorado, and Nebraska, and the Kansas-Republican/Smoky Hill and Osage in Kansas and Missouri. Each of these tributaries drains an area greater than $26,000 \mathrm{~km}^{2}$, and has an average discharge greater than $140 \mathrm{~m}^{3} / \mathrm{s}$.

The dominant land cover in the MORB is rangeland (51\% of the area), most of which is grass rangeland located in the western and central parts of the basin. Cultivated cropland accounts for about $25 \%$ of the area, the bulk of which is located in the eastern and southern parts of the basin. Corn and soybeans are the principal crops grown in the eastern portion of the basin and wheat and other small grain crops are the principal crops grown in the western portion. Agriculture in the MORB is not as inherently productive as in the UMRB or the OTRB because of lower precipitation and generally less fertile soils. Forestland accounts for $9 \%$ of the area, 
most of which is located in the west and in central Missouri. Permanent pasture and hay land represent only $6 \%$ of the area, and water, wetlands, horticulture, and barren land account for about $4 \%$ of the area. Urban areas comprise only a small part of the basin $(3 \%)$ and are concentrated near large cities like Denver, Colorado; Omaha, Nebraska; and Kansas City, Missouri. The remaining $2 \%$ of the area belongs to the Canada.

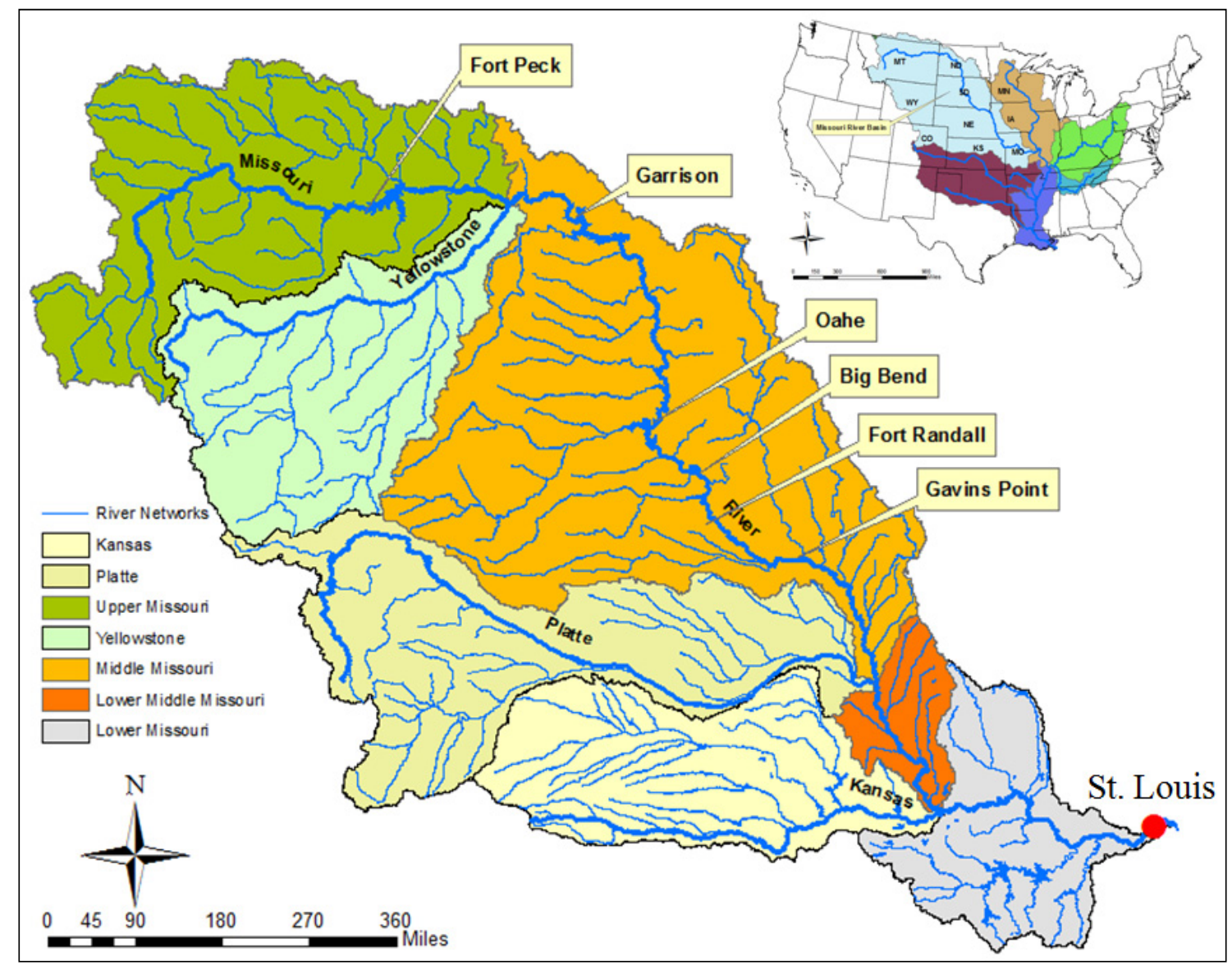

FIGURE 2 Location of the MORB and its major sub-basins and tributaries.

The MORB is an extremely diverse basin in many respects. The Rocky Mountains form the basin's western boundary. They have an exceptionally rugged topography. Its geography varies from the mountains of Colorado, Montana and Wyoming with some peaks as high as 14,000 feet above sea level to the low lands of Missouri of less than 500 feet. The climate varies from arid and semi-arid to sub-humid. Most of the basin receives an average of 200 to $250 \mathrm{~mm}$ of precipitation each year. However, the westernmost portions of the basin in the Rockies and the southeastern regions in Missouri may receive as much as $1,000 \mathrm{~mm}$. The vast majority of precipitation occurs in winter. Because of its mid-continent location, the MORB experiences large temperature fluctuations and extremes. Winter temperatures in Montana, Wyoming and Colorado may drop as low as $-51^{\circ} \mathrm{C}$, while summer highs in Kansas and Missouri have reached $49^{\circ} \mathrm{C}$. 
The input data needed to run the SWAT model include elevation, soil, land use, weather, management conditions, stream network, and watershed configuration data. The elevation data were represented by a 60m USGS Digital Elevation Model (DEM), while the State Soil Geographic (STATSGO) Database was used to define the soil properties and distribution. The physical soil properties needed by SWAT are texture, bulk density, available water capacity, saturated hydraulic conductivity, and soil albedo for up to 10 soil layers. The USDA National Agricultural Statistics Service (NASS) 2007-2010 Cropland Data Layer (CDL) was acquired and assessed to estimate land-cover types. The CDL was selected to represent land cover because of the great detail that is provided for the land cover-classes - specifically agricultural crops. The CDL contains crop-specific digital data layers and allows land cover to be categorized into specific agricultural land classes. The classification of interest in this study is row crops, which includes corn, soybeans, and wheat. Historical information on agricultural management was obtained from USGS, USDA. Table 1 summarizes the data used in this study as well as their sources and formats. Most of these datasets are downloadable through the public websites from the listed agencies.

TABLE 1 MORB data used in the SWAT model and their sources.

\begin{tabular}{lll}
\hline Dataset & Source of Data & Type of Data \\
\hline & & \\
Crop yield & USDA's National Agricultural Statistics Service & Text \\
& (NASS) & \\
Commercial fertilizer application & USDA's Economic Research Service (ERS) & Text \\
Manure application & USDA's National Agricultural Library - Water & Text \\
& Quality Information Center (WQIC); NASS & \\
Digital Elevation Model (DEM) & USEPA, Canada & Raster \\
8-digit Hydrologic Unit Code (HUC) & USGS & Shapefile \\
Stream network (RF1) & USEPA & Shapefile \\
Crop Data Layer (CDL) & USDA & Raster \\
State Soil Geographic (STATSGO) Data & ArcSWAT & Geodatabase \\
Tillage practice & USGS & Shapefile \\
Point sources & USEPA & Text \\
Atmospheric deposition & NADP & Text \\
Weather & USDA & Text \\
Tillage practice & Conservation Tillage Information Center (CTIC) & Text \\
\hline
\end{tabular}

Historical daily weather data from over 1800 NWS stations located throughout and surrounding the basin from 1960 until the end of September 2009 were obtained. The 50-year record is a serially complete daily data set of weather station data available from the NCDC (National Climatic Data Center) for the period 1960-2009, including precipitation, temperature maximum, and temperature minimum. The weather data were then screened for missing values and interpolated from the nearest weather station from which the data were available. Data for point source loading from permitted dischargers were estimated by using available monitoring 
data contained in the U.S. Environmental Protection Agency's Permit Compliance System (PCS). Thirty-seven (20 for the UMORB and 17 for the LOMORB) of point sources representing major wastewater treatment plants and industrial facilities were included and assigned with a daily constant nutrient flow in this study (Fig. 3).

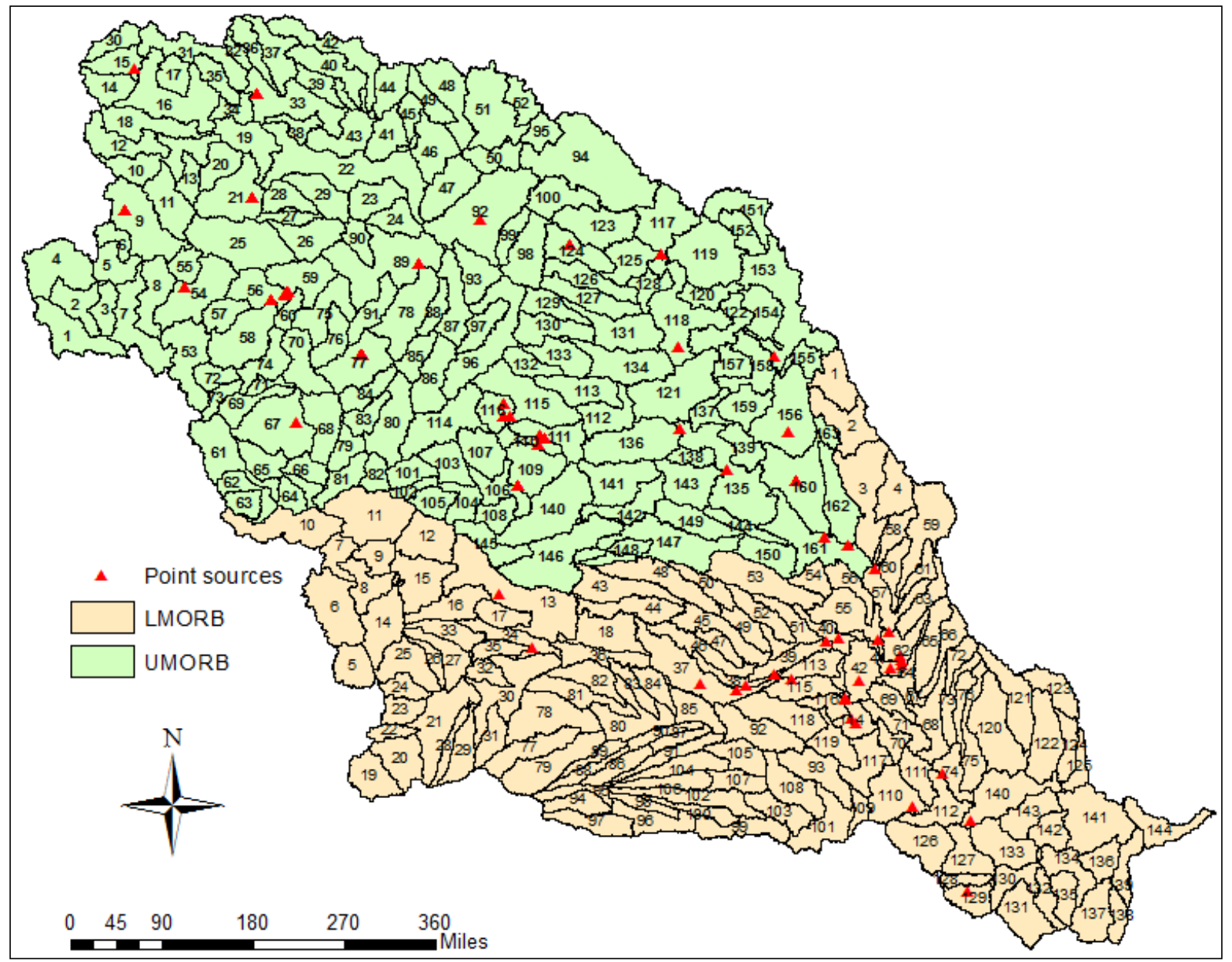

FIGURE 3 8-Digit hydrologic units (HUC) and major point source locations in the MORB.

The Missouri River Mainstem Reservoir System is comprised of six reservoirs that were constructed by the U.S. Army of Corps of Engineers. These six reservoirs contain about 73.4 million acre-feet of storage capacity, which constitutes over $52 \%$ of the total storage in the basin's reservoirs. This enormous capacity makes it the largest reservoir system in the U.S and one of the largest in North America. The six dams on the main stem system, Fort Peck, Garrison, Oahe, Big Bend, Fort Randell, and Gavins Point Dam are among the largest dams in the world by volume (Table 2). The Mainstem Reservoir System is a hydraulically and electrically integrated system that is regulated for flood control, navigation, hydropower, water supply, water quality, irrigation, recreation, and fish and wildlife. All these factors affect the timing and magnitude of Mainstem Reservoir System releases. The Mainstem Reservoir System is operated under the guidelines described in the Missouri River Mainstem System Master Water Control 
Manual (USACE, 2004). Reservoir characteristics such as storage volume, surface area, and maximum flow rate of the principal spillway and drainage area were obtained from National Inventory of Dams (NID) from the U.S. Army Corps of Engineers. Daily release data on major reservoirs and water transfers were obtained from the U.S. Army Corps of Engineer Omaha District, and used in this study.

TABLE 2 Missouri river main stem dams and reservoirs.

\begin{tabular}{llll}
\hline Dam & Reservoir & $\begin{array}{l}\text { Area } \\
\text { (acres) }\end{array}$ & $\begin{array}{l}\text { Volume } \\
\text { (acre-feet) }\end{array}$ \\
\hline Fort Peck Dam & Fort Peck Lake & 246,000 & $18,700,000$ \\
Garrison Dam & Lake Sakakawea & 384,480 & $23,000,000$ \\
Oahe Dam & Lake Oahe & 359,000 & $23,500,000$ \\
Big Bend Dam & Lake Sharpe & 63,000 & $1,900,000$ \\
Fort Randell Dam & Lake Francis Case & 95,000 & $5,500,000$ \\
Gavins Point Dam & Lewis \& Clark Lake & 29,000 & 492,000 \\
\hline
\end{tabular}

\section{MODEL DEVELOPMENT, CALIBRATION AND VALIDATION}

\subsection{MODEL SETUP AND PARAMETERIZATION}

Because of the size and complexity of the MORB, the MORB was divided into two watersheds. One is the Upper Missouri River Basin (UMORB) covering a drainage area of approximately $786,364 \mathrm{~km}^{2}$, the other one is the Lower Missouri River Basin (LMORB) covering a drainage area of approximately $562,936 \mathrm{~km}^{2}$. The UMORB outlet in this study is assumed to be at Sioux City, IA (Fig. 4). Two SWAT models were developed. SWAT results of the UMORB were used as the model inputs for the LMORB. A key aspect of the SWAT model parameterization is the delineation of the study watershed into sub-basin and then HRU units to facilitate the depiction of the wide range of climate, soils, land use, and management practices that exists in the watershed. 8-digit HUC watershed boundaries defined by the USEPA and USGS were selected as SWAT sub-basins in this study (Fig. 3). The UMORB was configured with 163 sub-basins. The LMORB includes 144 sub-basins. If sub-basins are predefined, the SWAT model requires a user-defined stream network data set to determine preferred flow paths within the sub-basin. The stream network is the primary means of surface water and water quality routing. The RF1 data set developed by the USGS and USEPA was used as the stream network layer for SWAT (Fig. 2).

To realistically simulate the baseline flow, sediment and water quality loadings, it is important to know the distribution of crop rotations in the MORB. Row crop agriculture in the MORB consisted of various rotational schedules and combinations utilizing mostly corn, soybean, and wheat crop production, whereas miscellaneous grain classes were combined as a general agricultural land. In this study, possible crop rotations were defined on the basis of the crops grown over the 4 years that information was obtained from 2007-2010 CDL data. All 
rotations repeat after the fourth year. Twenty-three rotations were developed for the UMORB on the basis of analyzing 4 years of CDL data. Predominant cropping systems in the LMORB are markedly different from those in the UMORB. Eighteen rotations were developed for the LMORB. The classes of crop rotations implemented in this study are given in Table 3 . Figure 4 presents land use and water features in the entire MORB in baseline year 2007.

TABLE 3 List of major crops and rotational classes.

\begin{tabular}{|c|c|c|c|}
\hline \multicolumn{2}{|c|}{ Upper Missouri River Basin } & \multicolumn{2}{|c|}{ Lower Missouri River Basin } \\
\hline $\begin{array}{l}\text { SWAT } \\
\text { Symbol }\end{array}$ & Crop Rotation & $\begin{array}{l}\text { SWAT } \\
\text { Symbol }\end{array}$ & Crop Rotation \\
\hline DWHT & Wheat & CORN & Corn \\
\hline CORN & Corn & SOYB & Soybean \\
\hline SOYB & Soybean & SWHT & Spring Wheat \\
\hline ALFA & Alfalfa & WWHT & Winter Wheat \\
\hline WWWI & Wheat-Wheat-Wheat-Idle & CSCS & Corn-Soyb-Corn-Soyb \\
\hline WWWH & Wheat-Wheat-Wheat-Hay & SCSC & Soyb-Corn-Soyb-Corn \\
\hline WWHW & Wheat-Wheat-Hay-Wheat & $\mathrm{CCSC}$ & Corn-Corn-Soyb-Corn \\
\hline WHWW & Wheat-Hay-Wheat-Wheat & $\mathrm{CSCC}$ & Corn-Soyb-Corn-Corn \\
\hline WCWW & Wheat-Corn-Wheat-Wheat & CCCS & Corn-Corn-Corn-Soyb \\
\hline WWWC & Wheat-Wheat-Wheat-Corn & $\mathrm{SCCC}$ & Soyb-Corn-Corn-Corn \\
\hline WWCW & Wheat-Wheat-Corn-Wheat & CSSS & Corn-Soyb-Soyb-Soyb \\
\hline CWWW & Corn-Wheat-Wheat-Wheat & SCCS & Soyb-Corn-Corn-Soyb \\
\hline $\mathrm{CSCC}$ & Corn-Soyb-Corn-Corn & CSSC & Corn-Soyb-Soyb-Corn \\
\hline CSHS & Corn-Soyb-Hay-Soyb & SCSS & Soyb-Corn-Soyb-Soyb \\
\hline $\mathrm{CCSC}$ & Corn-Corn-Soyb-Corn & SSCS & Soyb-Soyb-Corn-Soyb \\
\hline CSCS & Corn-Soyb-Corn-Soyb & $\mathrm{SSSC}$ & Soyb-Soyb-Soyb-Corn \\
\hline $\mathrm{CSCH}$ & Soyb-Corn-Soyb-Corn & CCSS & Corn-Corn-Soyb-Soyb \\
\hline SCSC & Corn-Soyb-Corn-Hay & SSCC & Soyb-Soyb-Corn-Corn \\
\hline HНHA & Hay-Hay-Hay-Alfalfa & & \\
\hline HHHW & Hay-Hay-Hay-Wheat & & \\
\hline HWWW & Hay-Wheat-Wheat-Wheat & & \\
\hline HAAA & Hay-Alfalfa-Alfalfa-Alfalfa & & \\
\hline
\end{tabular}

Each of the sub-basins was further divided into a number of spatially uniform HRUs on the basis of land use, soil type, and topography. First, the land-use categories required for the watershed simulations were determined, and then the different soil types that were associated with each land use were selected. Spatially varied values of soil physical properties (available water capacity, saturated conductivity, bulk density, texture, and organic matter) were assigned to different HRUs by SWAT on the basis of the STATSGO database. Finally, the land slope classes were assigned for each HRU. User-specified land cover, soil area and slope class thresholds can be applied that limit the number of HRUs in each sub-basin. For this study, the number of HRUs in SWAT was based on thresholds of 5\% for land use, 15\% for soil, and 10\% for slope. Because the study focuses on more crop cultivation and its impact, all croplands were exempted from the threshold — the cropland use category remains as a separate HRU even if the 
area is pretty small. With 163 sub-basins in the UMORB, these thresholds result in 14539 HRUs in the SWAT model. The LMORB SWAT model includes 8811 HRUs.

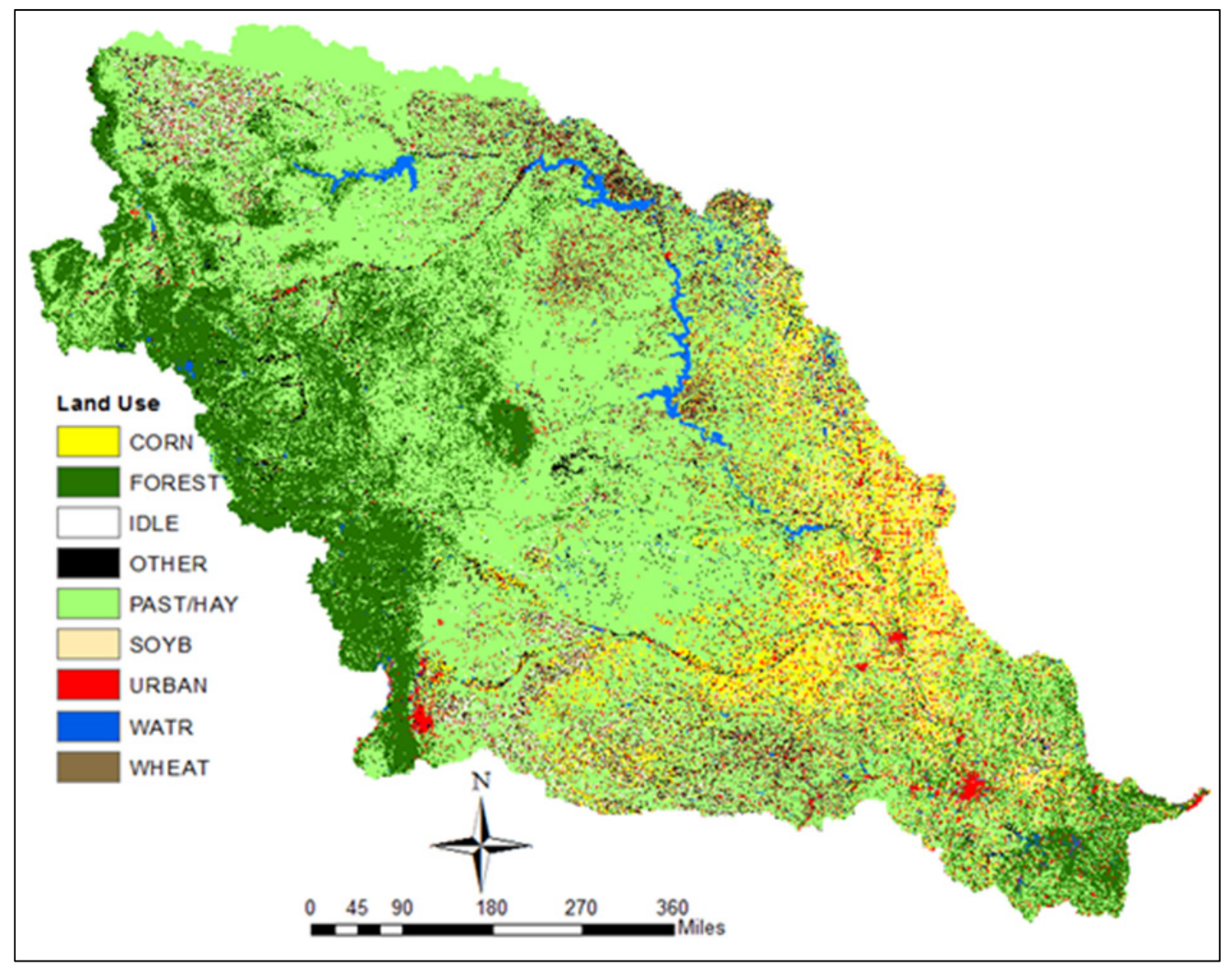

FIGURE 4 Land use of MORB under baseline year of 2007.

After HRU units were constructed, SWAT operation schedules were defined according to crop rotation patterns for each HRU individually as well as for corresponding practices (such as tillage, fertilizer application, crop planting, and crop harvesting). Typically, SWAT applies its default values for crop inputs unless otherwise instructed. Tillage systems include three types of conservation: tillage, reduced tillage, and intensive tillage. Tillage systems are defined on the basis of the amount of crop residue that remains on the soil after planting and resulting disturbance to the soil. Conservation tillage leaves at least one-third of the soil covered with crop residue after planting. Conservation tillage types include: no-till/strip-till, ridge-till, and mulchtill. No-till (NT) leaves more than 50\% residue. On NT agricultural fields, residue from the previous crop is left on the surface of the field and the soil is not disturbed by tillage. Reduced tillage (RT) leaves 15-30\% residue on the soil surface after planting. Reduced tillage or conservation tillage includes practices that result in less soil disturbance and less residue incorporation than standard tillage practices that leave fields bare. For the purposes of modeling, mulch tillage and conservation tillage were lumped together and refer to the category as RT. Intensive or conventional tillage (CT) involves full-width tillage. However, there is less than $15 \%$ residue on the soil surface after planting. Simulations of the use of residue and tillage practices were based on the survey data reported by the Conservation Technology Information 
Center (CTIC). The CTIC collects tillage data by conducting surveys about tillage systems for all counties in the United States. The CTIC county-level tillage data were aggregated to 8-digit hydrologic unit watersheds (HUC8) in the conterminous United States (Baker, 2011). The HUC8 datasets included planted acreage of conservation tillage (NT, ridge-till, and mulch-till), RT, and intensive or conventional tillage for selected crops for 1989-2004. A distribution of tillage for corn and soybean cultivated in the MORB is presented in Fig. 5 and Fig. 6.
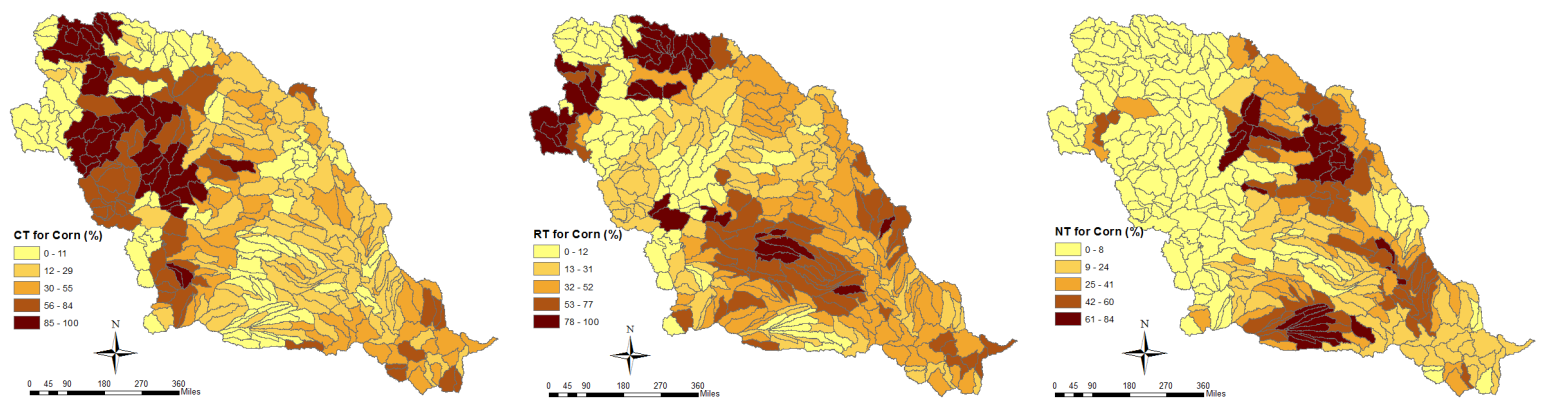

FIGURE 5 Percent of tillage practices under (a) CT, (b) RT, (c) NT for corn in the MORB baseline year.
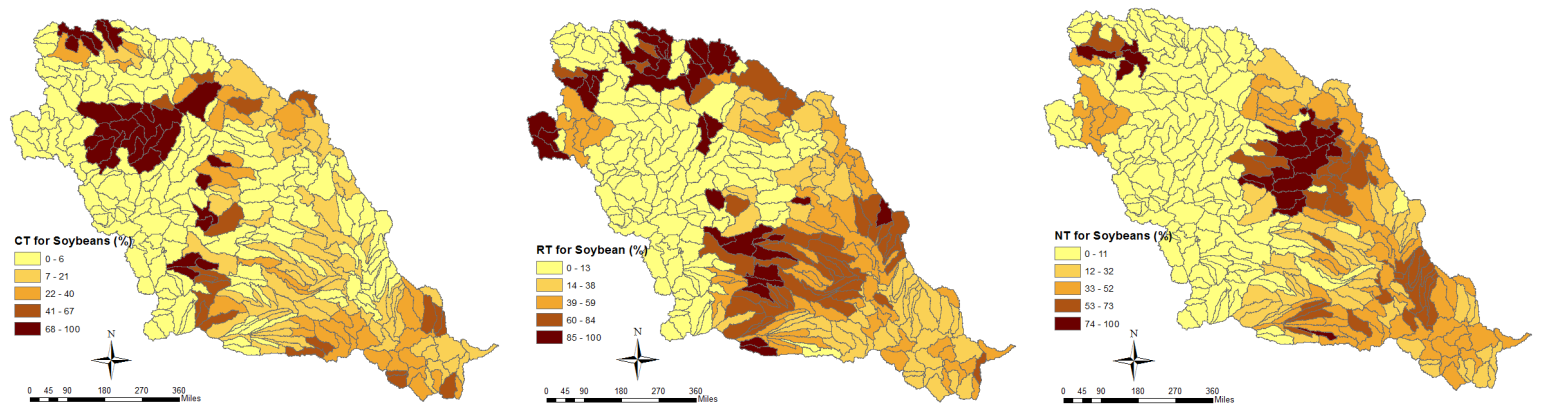

FIGURE 6 Percent of tillage practices under (a) CT, (b) RT, (c) NT for soybeans.

For corn and soybean crops in the model, CT included three tillage operations: chisel plowing either after harvest or in the spring before planting as the primary tillage, disk plowing in the spring as secondary tillage, and a pass with a field cultivator after planting. The disk plowing operation was eliminated under RT, and all tillage operations were eliminated under NT. Surface residue can intercept raindrops and prevent soil detachment, detain water in small pools, and retard the smooth flow of water over the surface of the soil (Unger and Kaspar, 1994). Increased roughness and decreased soil detachment can decrease the amount of sediment exported from a field. For corn and soybean crops, the initial Manning's N was raised from 0.12 to 0.22 for CT, to 0.32 for RT and for NT (DiLuzio et al., 2002). The SCS curve number recommendations for row crops list decreases from 1 to 4 points to account for additional infiltration on fields with reduced tillage (residue remaining). Biological mixing was raised from the default value of 0.2 to 0.3 for RT and 0.4 for NT. 
Commercial fertilizers are widely used on agricultural land in the MORB. State-level chemical fertilizer application has been reported by USDA. However, the distribution of fertilizer applications within the states is not well known, because the collection of county-level agricultural chemical use data by USDA was discontinued in 1990. Instead, state-level commercial fertilizer use over the croplands and hay lands in 2005 and 2006 was distributed at the county-level on the basis of crop yield distribution. The county-level fertilizer application rates were then aggregated back to the sub-basin level by using crop area and the weightedaverage method given below, by assuming that sub-basin application is directly proportional to crop acreage. When sub-basins only partially extended into one or more counties, county-level data were apportioned according to the amount of agricultural land contained within the subbasin, as described by Nakagaki and Wolock (2005).

Manure was applied over the crop and pasture lands. Its production was estimated for beef cattle, dairy cow, and swine grown in the UMRB states. Manure production was estimated for beef cattle, dairy cow, and swine grown in the UMRB according to USDA-NASS (2006a) county-level animal inventory data for 2005 (when available) or for the nearest year. Average manure output was calculated for beef, dairy, and swine according to a nutrient management program (University of Wisconsin Extension 2009). The county-level manure production was then distributed to the crop and hay lands in sub-basins. Since SWAT requires dry fresh manure without urine and feces, the observed fresh manure data were converted to dry weight via solids fractions of $14 \%, 14.7 \%$, and $13.1 \%$ for dairy, beef, and swine, respectively (ASAE, 2003).

Furthermore, there are noticeable discrepancies between the values used in SWAT and the ASAE (2003) standard for nutrient content in the manure (total nitrogen, ammonium, organic phosphorus, and mineral phosphorus). For example, organic nitrogen in dairy manure is $0.038 \mathrm{lb} / \mathrm{lb}$ dry weight, as recommended by ASAE (2003), while it is $0.031 \mathrm{lb} / \mathrm{lb}$ dry weight in SWAT. In particular, SWAT default values for swine differ significantly from the default ASAE values. The amount of organic nitrogen in swine manure suggested by ASAE $(0.047 \mathrm{lb} / \mathrm{lb}$ dry weight $)$ is more than twice that in SWAT $(0.021 \mathrm{lb} / \mathrm{lb}$ dry weight $)$, and the value of organic phosphorus suggested by ASAE is almost ten-fold higher than the SWAT value. For this modeling effort, we used the ASAE (2003) value to calculate the amount of nutrients in the manure and modify the existing SWAT fertilizer database.

Nitrogen and phosphorus is applied by using SWAT default scheduling, which fully meets crop nutrient requirements and there is no nutrient stress from the crop. Data for nitrogen in atmospheric deposition were derived from 1-km resolution grids of atmospheric deposition that were based on data from the National Atmospheric Deposition Program.

\subsection{MODEL CALIBRATION AND VALIDATION}

To capture the effects of weather, the MORB was simulated by using 20 years of actual daily weather data for the period 1990 through 2009. This period of record encompassed a wide range of climatic conditions including wet, dry and average years. SWAT model output for each individual riverine reach in the watershed consists of flow discharge, sediment and nutrient loads. Observed stream flow records are fundamental during the calibration and validation 
phases of SWAT model, as they make it possible to check if the value of each selected calibration parameter is suitable for the watershed of interest. Calibration and validation of MORB SWAT were based on a balanced, split-sample approach. Once configured and initially parameterized, SWAT models were run on a daily basis. In this study, available historical weather data (1990-2009) were divided into two datasets: 13 years (1990-2002) for calibration and 7 years for validation (2003-2009). The validation is used to evaluate the reliability of a calibrated model. SWAT models for the UMORB and LMORB were run for the 13-year period of 1990 through 2002. The first two years for the simulation period were treated to equilibrate to ambient conditions as warm-up years, and were not included in the model outputs. The stream flow predictions made by SWAT were compared with observed stream flow data at USGS gages in the MORB to evaluate the model's hydrologic predictions (Fig. 7). The USGS stream flow gage stations were screened for observed data availability, length and coverage of the data record. The final number of calibration sites for the MORB was 18 for stream flows, sediment, $\mathrm{TN}$, and TP. Stream flow and water quality data were obtained for each of the stream flow gage stations used in model calibration and validation from the USGS and the U.S. Army Corps of Engineers (USACE).

To avoid over parameterization, the initial group of calibration parameters was selected based on previous published studies that assessed the sensitivity of SWAT parameters, as well as, other Midwestern river basins, specifically Arnold et al. (1998); Santhi et al. (2001a, 2001b); Van Liew and Garbrecht (2003); Van Liew et al. (2005); White and Chaubey (2005); Neitsch et al. (2011). Calibration was completed by adjusting parameter values within their acceptable ranges to match simulated to observed stream flow at each of the USGS stream flow gage stations shown in Fig. 7.

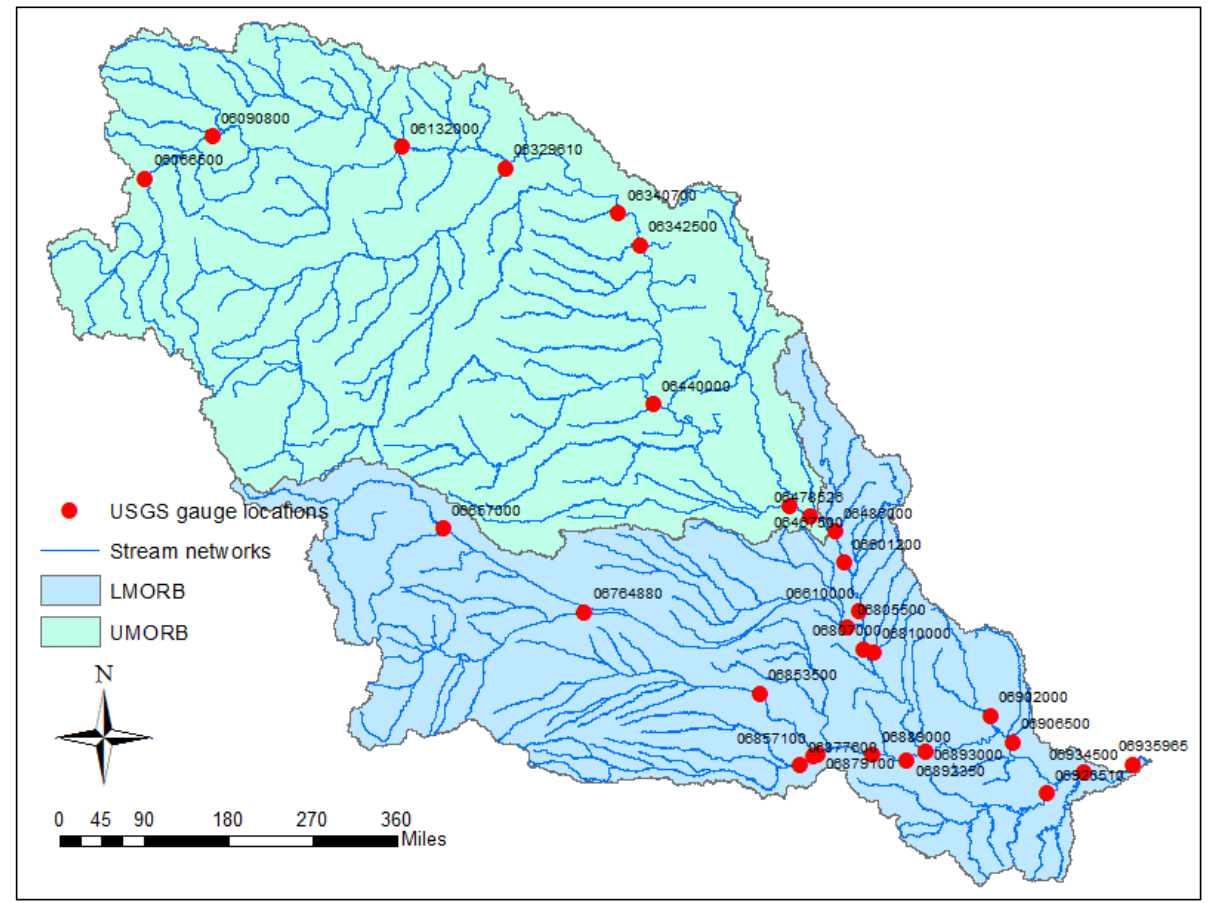

FIGURE 7 Locations of USGS stream flow gage stations in the MORB. 
To assess the model performance in regard to sediment and nutrient predictions, acceptable simulation of hydrology is important. During model calibration and validation, agreement between observed and modeled stream flows on an annual and monthly basis was evaluated visually and quantitatively. For the quantitative approach coefficient of determination $\left(\mathrm{R}^{2}\right)$, Nashe-Sutcliffe efficiency (NSE), Percent bias (PBIAS), and the ratio of the root mean square error (RMSE) to observations standard deviation (RSR) are used as evaluators of model performance.

$$
\begin{gathered}
R^{2}=\frac{\left(\sum_{i}\left(O V_{i}-\overline{O V}\right)\left(M V_{i}-\overline{M V}\right)\right)^{2}}{\sum_{i}\left(O V_{i}-\overline{O V}\right)^{2} \sum_{i}\left(M V_{i}-\overline{M V}\right)^{2}} \\
N S E=1.0-\frac{\sum_{i}\left(O V_{i}-M V_{i}\right)^{2}}{\sum_{i}\left(O V_{i}-\overline{O V}\right)^{2}} \\
\text { PBIAS }=\frac{\sum_{i}\left(O V_{i}-M V_{i}\right)}{\sum_{i} O V_{i}} * 100 \\
R S R=\frac{\sqrt{\frac{1}{n} \sum_{i}\left(O V_{i}-M V_{i}\right)^{2}}}{\sqrt{\frac{1}{n} \sum_{i}\left(O V_{i}-\overline{O V}\right)^{2}}}
\end{gathered}
$$

where $n$ is the number of observations during the simulation period, $O V_{i}$ is the observed value at the i time step, $\overline{O V}$ is the mean observed value for the rime period, $M V_{i}=$ modeled value at the i time step, $\overline{M V}$ is the mean modeled value for the time period.

$\mathrm{R}^{2}$, NSE, PBIAS, and RSR statistics are often used to evaluate model performance but there are no rules to determine if a 0.5 value for any statistic is good or bad. Moriasi et al. (2007) state that the monthly fits between simulated and observed stream flows can be considered "successful" when the NSE, PBIAS, and RSR for these individual fits are greater than $0.5(>0.5)$, less than 25 percent $(<25 \%)$, and less than $0.7(<0.7)$, respectively. The $\mathrm{R}^{2}$ indicates how well the plot of observed versus simulated data fit the $1: 1$ line, and a value of $\mathrm{R}=1.0$ indicates perfect fit. Gassman and others (2007) considered an $\mathrm{R}^{2}$ value of greater than 0.5 as satisfactory when comparing across multiple SWAT studies. In this study model calibration was first completed for average annual conditions, followed by average monthly conditions, starting with the farthest upstream stream flow gage station for each tributary and moving downstream to the next consecutive stream flow gage station. Performance was evaluated by determining the $\mathrm{R}^{2}$, NSE, PBIAS, and RSR for each stream flow gage station. 


\section{BASE MODEL CALIBRATION AND VALIDATION RESULTS}

Observed daily stream flows for 18 gage stations were available for the twenty-year period of 1990 through 2009 . These daily stream flows were used to calculate averaged annual and monthly stream flows. Monthly loads of suspended sediment (TSS), total nitrogen (TN) and total phosphorus (TP) were estimated by using averaged daily flow discharge rate and grab sample concentration measurements. These monthly based estimates may bring high uncertainty into model results, in particular, sample measurements of sediment, TN and TP at selected stations varied widely.

\subsection{HYDROLOGY}

Annual and monthly model calibration statistics, comparing observed and simulated stream flows for all gage stations, are presented in Table 4. Both SWAT models were validated by using observed stream flow data from the same USGS gages but for a different 7-year period (2003 through 2009) that was not used for model calibration. Table 5 displays statistical comparisons for the entire validation period.

Model results indicate that SWAT is capable of predicting MORB hydrology, calibration $\mathrm{R}^{2}$ and ENS values are greater than 0.5 for a majority of monitoring gages and at all of the time steps. The overall statistical indices for the entire period of annual calibration for all locations varied from 0.65 to 1.0 for $\mathrm{R}^{2}$, from 0.06 to 0.99 for ENS, and from 0.08 to 1.27 for RSR. Monthly calibration values ranged from 0.29 to 0.86 for $\mathrm{R}^{2}$, from 0.14 to 0.81 for ENS, and from 0.5 to 1.01 for RSR. Annual and monthly calibration PBIAS ranged from $-44 \%$ to $1.8 \%$ and $-44 \%$ to $2.8 \%$ respectively. Annual and monthly PBIAS results indicate satisfactory to very good model performance. In fact, NSE, PBIAS, and RSR statistic values were mostly "good" with a few exceptions according to criteria developed by Moriasi et al. (2007). There were decreases and increases in the $\mathrm{R}^{2}$, ENS, PBIAS and RSR values for the validation period relative to calibration. Somewhat surprisingly, SWAT prediction of stream flow was more accurate during the calibration period than the validation time period overall. Decreases in model performance during the validation period can be attributed to a number of factors, such as projecting calibration parameters from one sub-basin to another sub-basin that has vastly different physical characteristics or land cover and management practices, or both. Though all SWAT models performed well, across the MORB, stream flow was best predicted for the outlets of the UMORB and LMORB. The ENS values for all time steps for calibration and validation for the MORB outlet, the Missouri River near St. Louis, MO, station ranged from 0.75 to $0.92, \mathrm{R}^{2}$ values ranged from 0.86 to 0.97 , while PBIAS was less than $7 \%$. The model performance based on the statistical measures is very good. The high $\mathrm{R}^{2}$ and the NSE indicate that the model is predicting watershed hydrology well. However, a high RSR (RMSE) is indicative of the model not predicting peaks well. The theory and mathematical equations used in SWAT are for long term simulation with less emphasis on event flows (Borah and Berra, 2003a; SWAT, 2005a), which is evident in Fig. 8 and Fig. 9. 
TABLE 4 Hydrology calibration (1990-2002) results for each stream flow gage station.

\begin{tabular}{|c|c|c|c|c|c|c|c|}
\hline \multirow[t]{2}{*}{$\begin{array}{l}\text { USGS } \\
\text { Station } \\
\end{array}$} & \multirow[t]{2}{*}{$\begin{array}{l}\text { SWAT Sub- } \\
\text { basin }\end{array}$} & \multicolumn{2}{|c|}{ Mean $\left(\mathbf{m}^{3} / \mathbf{s}\right)$} & \multirow[t]{2}{*}{$\mathbf{R}^{2}$} & \multirow[t]{2}{*}{ NSE } & \multirow[t]{2}{*}{ PBIAS (\%) } & \multirow[t]{2}{*}{ RSR } \\
\hline & & Observed & Modeled & & & & \\
\hline \multicolumn{8}{|c|}{ Annual Calibration } \\
\hline \multicolumn{8}{|c|}{ Upper Missouri River Basin } \\
\hline 06066500 & 9 & 136.79 & 143.54 & 0.67 & 0.45 & -4.94 & 0.58 \\
\hline 06090800 & 10 & 174.44 & 203.21 & 0.67 & 0.22 & -16.49 & 0.70 \\
\hline 06115200 & 19 & 216.02 & 244.90 & 0.65 & 0.41 & -13.37 & 0.67 \\
\hline 06185500 & 50 & 251.30 & 258.52 & 0.91 & 0.90 & -2.87 & 0.30 \\
\hline 06329500 & 92 & 285.20 & 332.08 & 0.68 & 0.25 & -16.44 & 0.69 \\
\hline 06342500 & 117 & 571.95 & 612.32 & 0.78 & 0.74 & -7.06 & 0.60 \\
\hline 06486000 & 161 & 929.81 & 966.30 & 0.97 & 0.95 & -3.92 & 0.37 \\
\hline \multicolumn{8}{|c|}{ Lower Missouri River Basin } \\
\hline 06610000 & 62 & 1095.05 & 1067.46 & 0.96 & 0.95 & 2.52 & 0.21 \\
\hline 06807000 & 64 & 1269.71 & 1446.07 & 0.94 & 0.62 & -13.89 & 1.27 \\
\hline 06810000 & 67 & 52.68 & 76.08 & 0.90 & 0.06 & -44.41 & 0.93 \\
\hline 06857100 & 93 & 27.91 & 18.26 & 0.86 & 0.59 & 34.58 & 1.27 \\
\hline 06877600 & 101 & 58.10 & 49.33 & 0.82 & 0.79 & 15.10 & 0.44 \\
\hline 06879100 & 109 & 98.74 & 76.39 & 0.87 & 0.77 & 22.63 & 0.46 \\
\hline 06889000 & 110 & 209.52 & 184.40 & 0.89 & 0.86 & 11.99 & 1.27 \\
\hline 06892350 & 112 & 268.15 & 255.51 & 0.91 & 0.90 & 4.71 & 0.30 \\
\hline 06902000 & 122 & 138.87 & 199.54 & 0.90 & 0.14 & -43.69 & 0.89 \\
\hline 06926510 & 136 & 327.50 & 321.52 & 1.00 & 0.99 & 1.83 & 0.08 \\
\hline 06935965 & 144 & 2884.93 & 3067.50 & 0.97 & 0.92 & -6.33 & 0.28 \\
\hline \multicolumn{8}{|c|}{ Monthly Calibration } \\
\hline \multicolumn{8}{|c|}{ Upper Missouri River Basin } \\
\hline 06066500 & 9 & 136.65 & 143.59 & 0.31 & 0.16 & -5.08 & 1.00 \\
\hline 06090800 & 10 & 174.30 & 203.23 & 0.48 & 0.14 & -16.59 & 0.77 \\
\hline 06115200 & 19 & 220.71 & 244.87 & 0.50 & 0.15 & -10.95 & 0.73 \\
\hline 06185500 & 50 & 251.41 & 258.55 & 0.56 & 0.55 & -2.84 & 0.90 \\
\hline 06329500 & 92 & 284.94 & 331.94 & 0.28 & -0.38 & -16.49 & 0.89 \\
\hline 06342500 & 117 & 571.25 & 612.15 & 0.40 & 0.35 & -7.16 & 1.01 \\
\hline 06486000 & 161 & 854.58 & 965.16 & 0.88 & 0.81 & -12.94 & 0.44 \\
\hline \multicolumn{8}{|c|}{ Lower Missouri River Basin } \\
\hline 06610000 & 62 & 1093.78 & 1065.14 & 0.82 & 0.74 & 2.62 & 0.51 \\
\hline 06807000 & 64 & 1268.61 & 1442.78 & 0.80 & 0.23 & -13.73 & 0.87 \\
\hline 06810000 & 67 & 52.63 & 75.89 & 0.76 & 0.03 & -44.19 & 0.98 \\
\hline 06857100 & 93 & 27.81 & 18.18 & 0.29 & 0.19 & 34.64 & 0.89 \\
\hline 06877600 & 101 & 57.99 & 49.08 & 0.77 & 0.75 & 15.36 & 0.50 \\
\hline 06879100 & 109 & 98.53 & 76.05 & 0.79 & 0.76 & 22.82 & 0.49 \\
\hline 06889000 & 110 & 209.05 & 183.61 & 0.76 & 0.73 & 12.17 & 0.51 \\
\hline 06892350 & 112 & 267.64 & 254.63 & 0.75 & 0.70 & 4.86 & 0.55 \\
\hline 06902000 & 122 & 138.89 & 199.03 & 0.73 & 0.64 & -43.30 & 0.60 \\
\hline 06926510 & 136 & 851.05 & 956.67 & 0.83 & 0.78 & -12.41 & 0.47 \\
\hline 06935965 & 144 & 2883.29 & 3061.85 & 0.86 & 0.75 & -6.19 & 0.50 \\
\hline
\end{tabular}


TABLE 5 Hydrology validation (2003-2009) results for each stream flow gage station.

\begin{tabular}{|c|c|c|c|c|c|c|c|}
\hline \multirow[t]{2}{*}{$\begin{array}{l}\text { USGS } \\
\text { Station } \\
\end{array}$} & \multirow[t]{2}{*}{$\begin{array}{l}\text { SWAT Sub- } \\
\text { basin }\end{array}$} & \multicolumn{2}{|c|}{$\operatorname{Mean}\left(\mathbf{m}^{3} / \mathbf{s}\right)$} & \multirow[t]{2}{*}{$\mathbf{R}^{2}$} & \multirow[t]{2}{*}{ NSE } & \multirow[t]{2}{*}{ PBIAS (\%) } & \multirow[t]{2}{*}{ RSR } \\
\hline & & Observed & Modeled & & & & \\
\hline \multicolumn{8}{|c|}{ Annual Validation } \\
\hline \multicolumn{8}{|c|}{ Upper Missouri River Basin } \\
\hline 06066500 & 9 & 78.10 & 112.61 & 0.58 & -6.18 & -44.19 & 2.45 \\
\hline 06090800 & 10 & 99.98 & 162.44 & 0.77 & -4.15 & -62.46 & 2.07 \\
\hline 06115200 & 19 & 117.33 & 191.38 & 0.87 & -2.95 & -63.12 & 1.81 \\
\hline 06185500 & 50 & 197.98 & 194.82 & 0.91 & 0.89 & 1.60 & 0.30 \\
\hline 06329500 & 92 & 236.43 & 239.86 & 0.04 & -0.63 & -1.45 & 1.17 \\
\hline 06342500 & 117 & 400.25 & 456.49 & 0.72 & -0.48 & -14.05 & 1.11 \\
\hline 06486000 & 161 & 629.85 & 619.80 & 0.08 & -0.18 & 1.60 & 0.99 \\
\hline \multicolumn{8}{|c|}{ Lower Missouri River Basin } \\
\hline 06610000 & 62 & 706.10 & 811.70 & 0.02 & -19.61 & -14.96 & 4.14 \\
\hline 06807000 & 64 & 883.98 & 1248.42 & 0.76 & -25.27 & -41.23 & 4.68 \\
\hline 06810000 & 67 & 45.14 & 73.91 & 0.95 & -0.29 & -63.72 & 1.04 \\
\hline 06857100 & 93 & 10.74 & 25.99 & 0.78 & -8.11 & -142.06 & 2.75 \\
\hline 06877600 & 101 & 23.69 & 66.05 & 0.96 & -9.20 & -178.76 & 2.92 \\
\hline 06879100 & 109 & 38.15 & 103.22 & 0.98 & -10.29 & -170.59 & 3.07 \\
\hline 06889000 & 110 & 110.25 & 254.83 & 0.95 & -6.99 & -131.13 & 2.58 \\
\hline 06892350 & 112 & 149.75 & 328.67 & 0.96 & -5.56 & -119.47 & 2.34 \\
\hline 06902000 & 122 & 112.29 & 158.92 & 0.93 & 0.66 & -41.53 & 0.53 \\
\hline 06926510 & 136 & 311.16 & 328.68 & 1.00 & 0.99 & -5.63 & 0.10 \\
\hline 06906500 & 140 & 1493.05 & 2102.67 & 0.96 & -1.15 & -40.83 & 1.34 \\
\hline 06935965 & 144 & 2035.30 & 2796.67 & 0.99 & -0.29 & -37.41 & 1.04 \\
\hline \multicolumn{8}{|c|}{ Monthly Validation } \\
\hline \multicolumn{8}{|c|}{ Upper Missouri River Basin } \\
\hline 06066500 & 9 & 83.70 & 117.92 & 0.31 & -0.31 & -40.88 & 1.14 \\
\hline 06090800 & 10 & 107.59 & 169.18 & 0.51 & -0.76 & -57.25 & 1.32 \\
\hline 06115200 & 19 & 231.51 & 199.02 & 0.43 & 0.20 & 14.03 & 0.89 \\
\hline 06185500 & 50 & 195.74 & 192.98 & 0.55 & 0.54 & 1.41 & 0.67 \\
\hline 06329500 & 92 & 231.94 & 259.43 & 0.14 & -0.48 & -11.85 & 1.21 \\
\hline 06342500 & 117 & 410.50 & 457.78 & 0.25 & 0.18 & -11.52 & 0.90 \\
\hline 06486000 & 161 & 588.50 & 634.01 & 0.70 & 0.66 & -7.73 & 0.58 \\
\hline \multicolumn{8}{|c|}{ Lower Missouri River Basin } \\
\hline 06610000 & 62 & 719.61 & 821.88 & 0.73 & -0.44 & -14.21 & 1.19 \\
\hline 06807000 & 64 & 901.09 & 1275.40 & 0.75 & -3.13 & -41.54 & 2.02 \\
\hline 06810000 & 67 & 46.02 & 74.70 & 0.88 & 0.36 & -62.32 & 0.80 \\
\hline 06857100 & 93 & 10.95 & 27.50 & 0.22 & -6.99 & -151.22 & 2.81 \\
\hline 06877600 & 101 & 24.59 & 67.65 & 0.62 & -2.34 & -175.09 & 1.82 \\
\hline 06879100 & 109 & 39.83 & 106.48 & 0.73 & -3.98 & -167.34 & 2.22 \\
\hline 06889000 & 110 & 112.95 & 256.11 & 0.70 & -2.27 & -126.75 & 1.80 \\
\hline 06892350 & 112 & 372.21 & 357.49 & 0.74 & 0.68 & 3.95 & 0.56 \\
\hline 06902000 & 122 & 126.16 & 186.09 & 0.63 & 0.39 & -47.50 & 0.78 \\
\hline 06926510 & 136 & 332.68 & 349.36 & 0.99 & 0.99 & -5.01 & 0.09 \\
\hline 06906500 & 140 & 1558.98 & 2180.52 & 0.82 & -0.07 & -39.87 & 1.03 \\
\hline 06935965 & 144 & 2134.11 & 2912.17 & 0.84 & 0.20 & -36.46 & 0.89 \\
\hline
\end{tabular}


One of the drawbacks of $\mathrm{R}^{2}$ and ENS for model evaluation is that both indices can be satisfactory while the model in general is over- or under-predicting (Krause et al., 2005).

Therefore, observed and predicted stream flows were visually compared for the period of study. Time-series plots of modeled and observed annual and monthly stream flows are only shown for the UMORB and LMORB outlet gages (Figs. 8, 9). These figures show the seasonal changes in modeled and observed annual and monthly stream flows over the entire calibration and verification periods, respectively. SWAT generally overestimated peak flows. Overall comparative plots of observed and simulated stream flows along the mainstem and tributaries, and at different locations, indicated satisfactory simulation of the MORB hydrology.
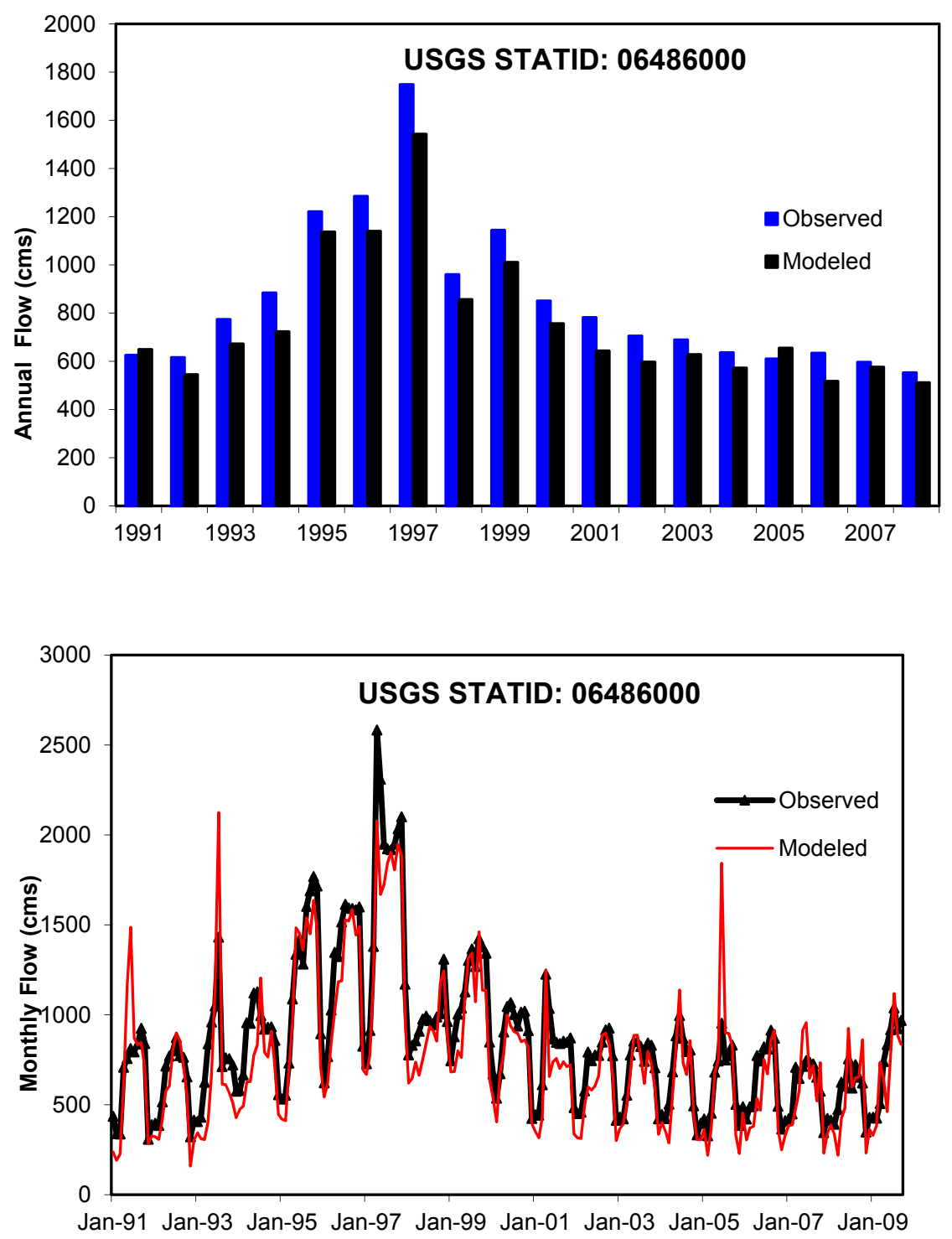

FIGURE 8 Time series plots of observed and modeled annual (top) and monthly (bottom) mean stream flow $\left(\mathrm{m}^{3} / \mathrm{s}\right)$ over the calibration (1990-2002) and validation (2003-2009) time periods at the outlet of UMORB. 

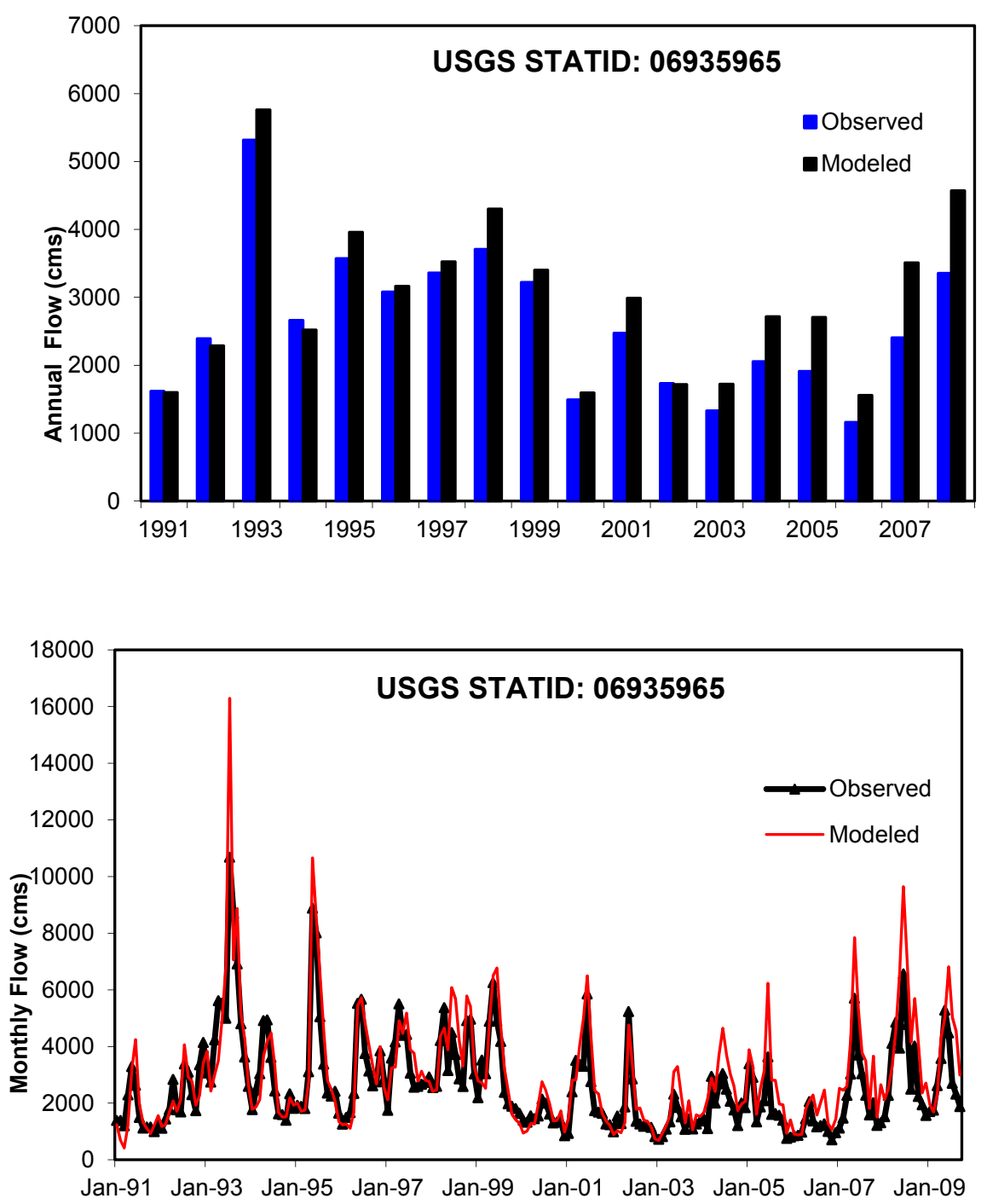

FIGURE 9 Time series plots of observed and modeled annual (top) and monthly (bottom) mean stream flow $\left(\mathrm{m}^{3} / \mathrm{s}\right)$ over the calibration (1990-2002) and validation (2003-2009) periods for the gage at LMORB outlet.

A comparison of monthly observed stream flows to the simulated/observed stream flow ratios $(\mathrm{S} / \mathrm{O})$ is shown in Fig. 10. Scatter plots of observed stream flow versus $\mathrm{S} / \mathrm{O}$ ratio were used to determine if there were any systematic errors related to the magnitude of the observed monthly stream flows. Mean monthly flows were estimated well by SWAT as indicated by the uniform scatter of points around the $\mathrm{S} / \mathrm{O}$ equal to 1 line in Fig.10. Fig. 10 shows that the flow residuals are randomly distributed with no bias. Fig. 11 shows the flow duration values of simulated and observed monthly stream flows. The monthly stream flow duration curves confirm the SWAT tendency to slightly overestimate peak flows. Overall, both models estimated the daily flows as satisfactorily. It should be noted that these modeled results were obtained by using the DEM, soil, land use, and weather data from readily available data sources. SWAT predicted well measured stream flow for all gauges during both the calibration and validation periods. 

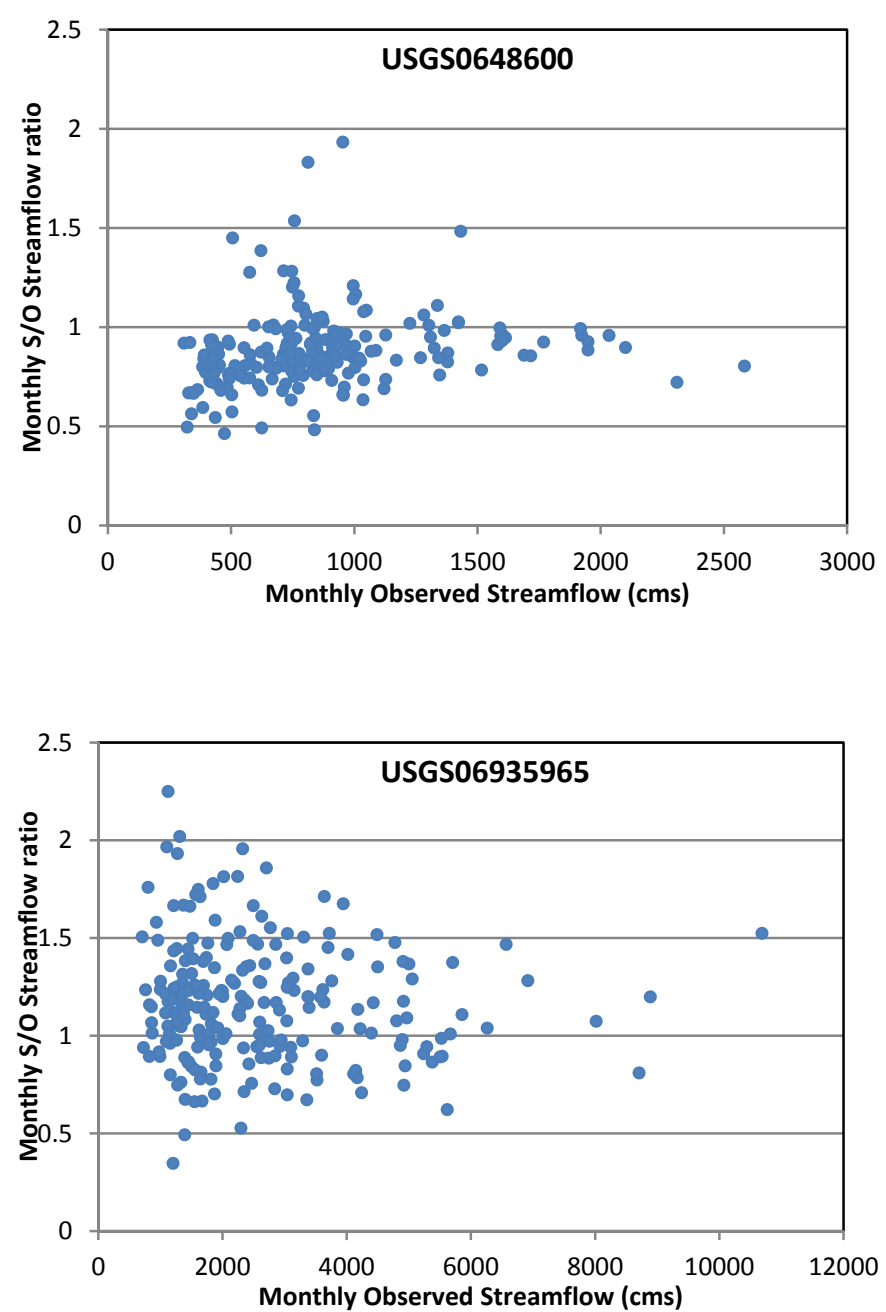

FIGURE 10 Scatter plots of monthly observed stream flow versus monthly simulated/observed stream flow ratio for the calibration and validation period for the outlet of UMORB and LMORB. 

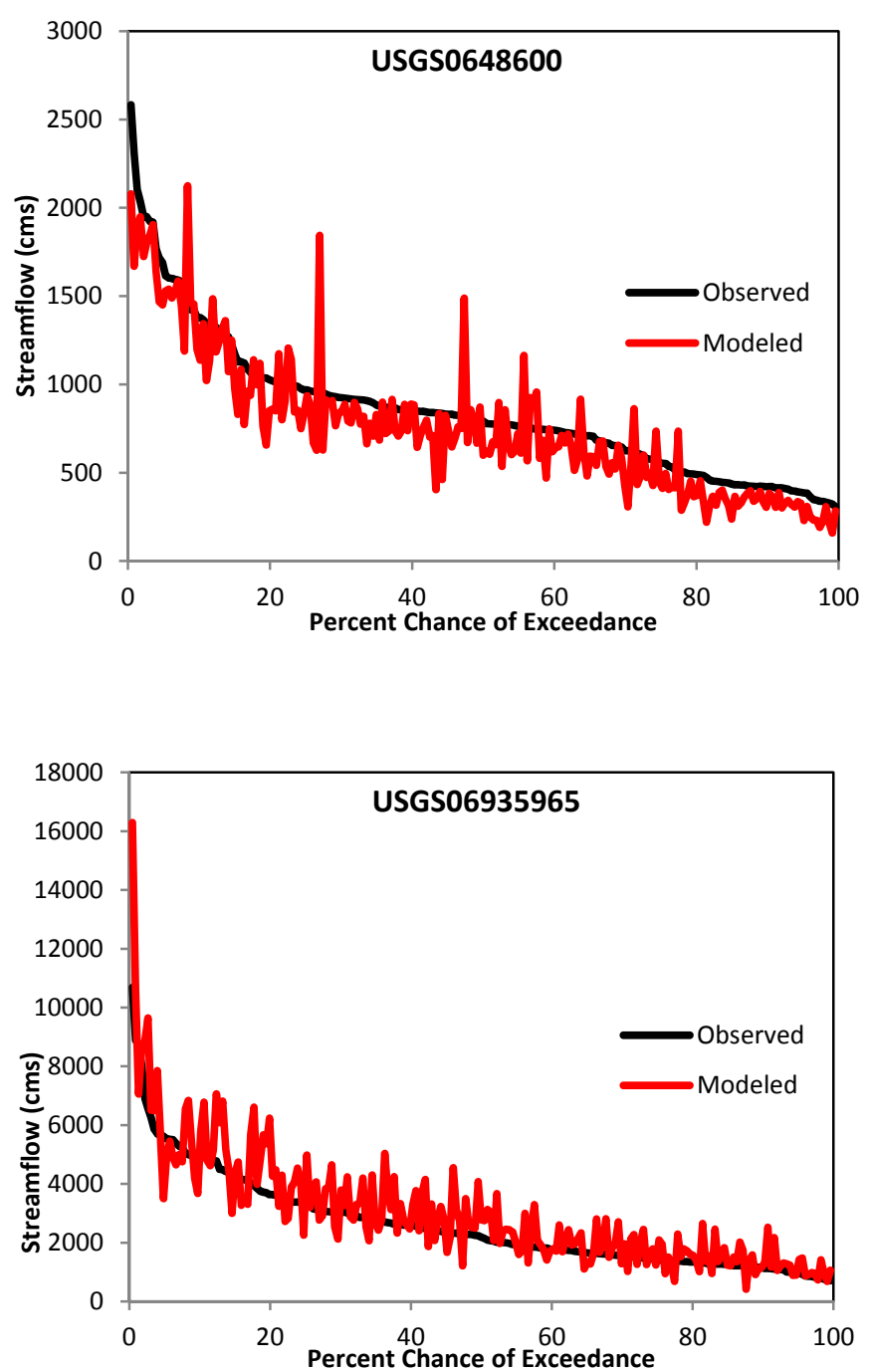

FIGURE 11 Observed and simulated monthly stream flow duration curves for the model calibration and validation time period.

\subsection{TOTAL SUSPENDED SEDIMENT}

After the model hydrology is calibrated, total suspended sediment calibration is performed accordingly for the MORB. The USGS, in cooperation with the USACE, has collected and analyzed suspended-sediment data in the Missouri River. Annual suspendedsediment loads and yields for 18 stations within the LMORB were provided by Heimann et al. (2010). At each station, annual suspended-sediment loads were computed by using available data for water years 1976 through 2008 (defined as the 12-month period from October 1 through September 30). In addition, sparse measurements of TSS concentrations from collected samples were also available for six USGS gauge stations (Table 7). Sediment calibration statistics for annual and monthly suspended-sediment loads at six selected stations for the period encompassing 1990-2009 are presented in Tables 6 and 7. The periods used for the summary 
statistics of the annual and monthly sediment loads vary by station because they are limited to available data.

TABLE 6 Annual sediment calibration and validation results for selected stream flow gages.

\begin{tabular}{|c|c|c|c|c|c|c|c|}
\hline \multirow[t]{2}{*}{$\begin{array}{l}\text { USGS } \\
\text { Station }\end{array}$} & \multirow[t]{2}{*}{$\begin{array}{l}\text { SWAT Sub- } \\
\text { basin }\end{array}$} & \multicolumn{2}{|c|}{ Mean (tons/yr) } & \multirow[t]{2}{*}{$\mathbf{R}^{2}$} & \multirow[t]{2}{*}{ NSE } & \multirow[t]{2}{*}{ PBIAS (\%) } & \multirow[t]{2}{*}{ RSR } \\
\hline & & Observed & Modeled & & & & \\
\hline \multicolumn{8}{|c|}{ Calibration (1990-2002) } \\
\hline 06486000 & 161 & 9881504 & 9888100 & 0.92 & 0.92 & -0.07 & 0.27 \\
\hline 06805500 & 41 & 16774166 & 8591166 & 0.36 & 0.09 & 48.78 & 0.91 \\
\hline 06610000 & 62 & 17167500 & 23940408 & 0.88 & 0.17 & -39.45 & 0.87 \\
\hline 06807000 & 64 & 27625000 & 30291450 & 0.82 & 0.74 & -9.65 & 0.49 \\
\hline 06906500 & 140 & 57091666 & 34840100 & 0.87 & 0.50 & 38.98 & 0.68 \\
\hline 06935965 & 144 & 74590909 & 56831036 & 0.95 & 0.78 & 23.81 & 0.45 \\
\hline \multicolumn{8}{|c|}{ Validation (2003-2009) } \\
\hline 06486000 & 161 & 3498680 & 4403666 & 0.66 & -0.07 & -25.87 & 0.94 \\
\hline 06805500 & 41 & 772333 & 7796351 & 0.53 & 0.34 & -0.95 & 0.74 \\
\hline 06807000 & 64 & 18421666 & 21761916 & 0.42 & -0.40 & -18.13 & 1.08 \\
\hline 06877600 & 101 & 1163165 & 813315 & 0.66 & 0.56 & 30.08 & 0.61 \\
\hline 06906500 & 140 & 34783333 & 21775200 & 0.19 & -0.48 & 37.40 & 1.11 \\
\hline 06935965 & 144 & 39596666 & 32373950 & 0.33 & 0.25 & 18.24 & 0.79 \\
\hline
\end{tabular}

TABLE 7 Monthly sediment calibration and validation results for selected stream flow gages.

\begin{tabular}{|c|c|c|c|c|c|c|c|}
\hline \multirow[t]{2}{*}{$\begin{array}{l}\text { USGS } \\
\text { Station } \\
\end{array}$} & \multirow[t]{2}{*}{$\begin{array}{l}\text { SWAT Sub- } \\
\text { basin }\end{array}$} & \multicolumn{2}{|c|}{ Mean (tons/month) } & \multirow[t]{2}{*}{$\mathbf{R}^{2}$} & \multirow[t]{2}{*}{ NSE } & \multirow[t]{2}{*}{ PBIAS (\%) } & \multirow[t]{2}{*}{ RSR } \\
\hline & & Observed & Modeled & & & & \\
\hline \multicolumn{8}{|c|}{ Calibration (1990-2002) } \\
\hline 06486000 & 161 & 869706 & 640682 & 0.48 & 0.57 & 1.78 & 0.69 \\
\hline 06610000 & 62 & 1536291 & 2012525 & 0.52 & -0.49 & -39.73 & 1.23 \\
\hline 06807000 & 64 & 2468982 & 2541009 & 0.57 & 0.36 & -9.78 & -0.80 \\
\hline \multicolumn{8}{|c|}{ Validation (2003-2009) } \\
\hline 06486000 & 161 & 312116 & 399094 & 0.35 & -1.3 & -27.87 & 1.51 \\
\hline 06807000 & 64 & 1528001 & 2418801 & 0.54 & -0.32 & -58.30 & 1.14 \\
\hline 06877600 & 101 & 94858 & 68754 & 0.49 & 0.33 & 27.52 & 0.81 \\
\hline 06935965 & 144 & 2578205 & 2949311 & 0.83 & 0.80 & -14.39 & 0.44 \\
\hline
\end{tabular}

Time-series plots of modeled and observed annual and monthly TSS loads are shown for the UMORB and LMORB outlet locations (Figs. 12, 13). These figures show the seasonal changes in modeled and observed annual and monthly TSS loads, respectively. For the MORB outlet, no observed sediment data suitable for calibration were available; sediment load for this location was plotted only for the validation period. With respect to TSS, the model calibration 
shows that over-predictions occur during low flow events and that some large flow events are not simulated well (Fig. 12). In fact, $\mathrm{R}^{2}$ and ENS indices for the calibration and validation period were "good" for six gage stations according to the ranges given by Moriasi et al. (2007). Sediment loads were best predicted for the MORB outlet. $\mathrm{R}^{2}$ and ENS values represent a significant relationship between predicted and observed values of TSS. PBIAS values were largely categorized as "good" across all watersheds, indicating that model predictions of riverine TSS loads were not generally higher or lower than observed data. Thus, SWAT predicted riverine TSS loads accurately on average.
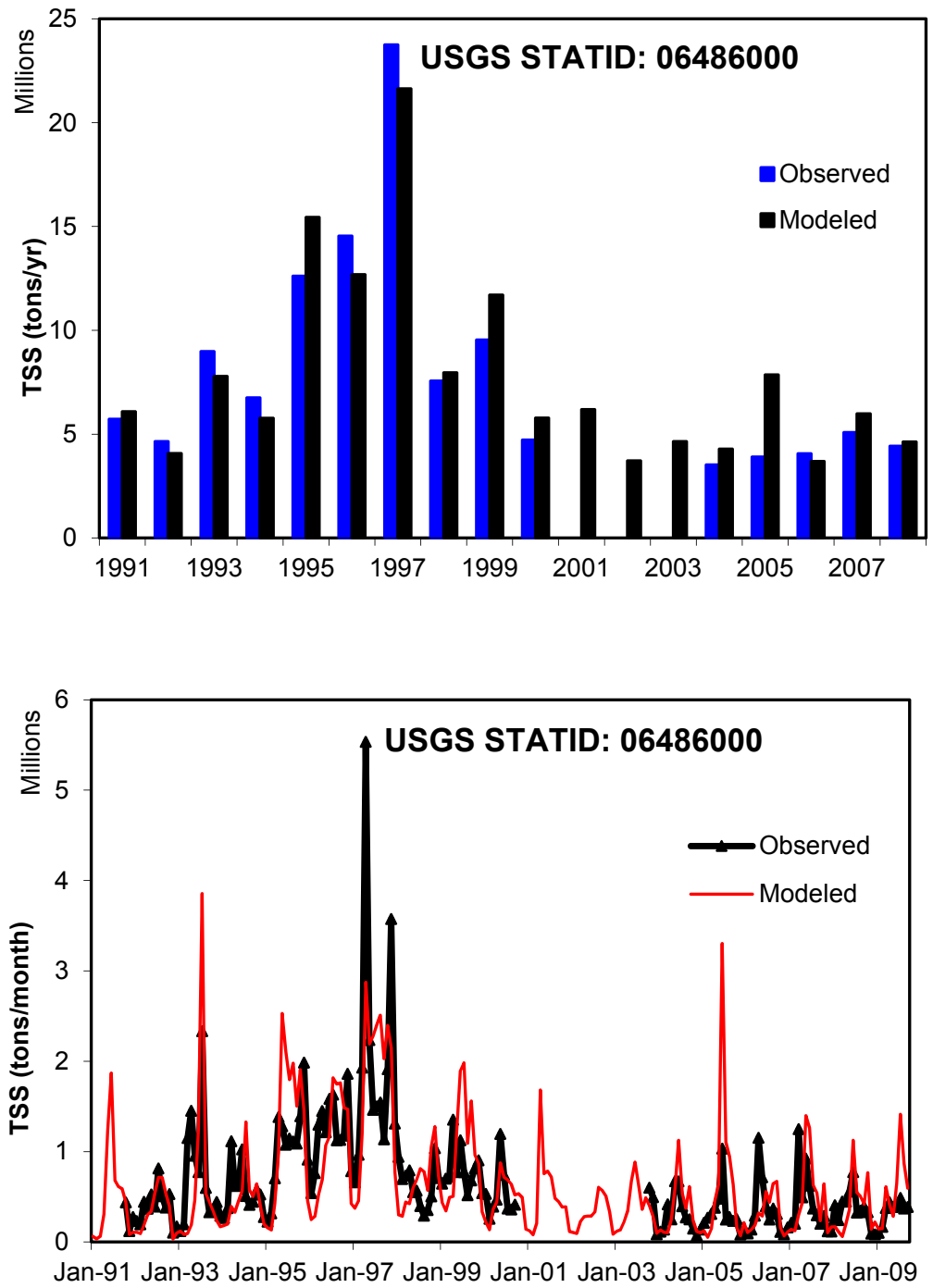

Figure 12 Time series plots of observed and modeled annual (top) and monthly (bottom) riverine total suspended sediment loads of a monitoring gage over the calibration (1990-2002) and validation (2003-2009) periods. 

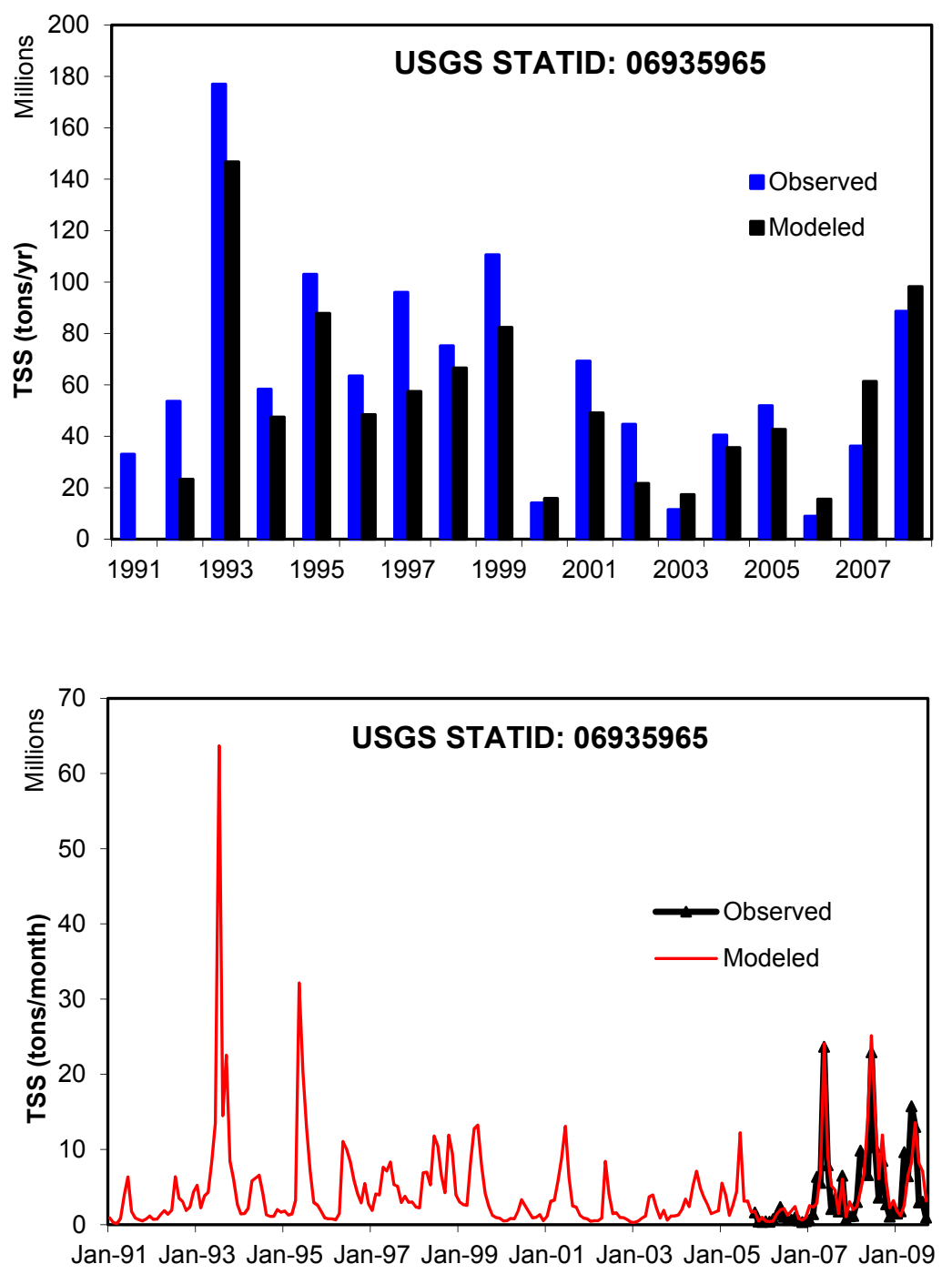

FIGURE 13 Time series plots of observed and modeled annual (top) and monthly (bottom) riverine total suspended sediment loads of a monitoring gage over the calibration (1990-2002) and validation (2003-2009) periods.

\subsection{NITROGEN AND PHOSPHORUS}

Regarding nutrient (N, P) data, measurements of NH4, NO3, TKN, or TN and TP concentrations from collected samples were available for six USGS gage stations for the period 1990-2009. In general monthly grab-sample data were available for these stations, limiting the data available for model calibration. In addition, the monthly data were used to estimate average monthly and yearly values. Additional errors may be introduced to make these average measured estimates for use in calibration. Riverine TN and TP concentrations were compiled for each calibration site by using either direct measurements or, where possible, a summation of component nutrient species. The technique of comparing riverine $\mathrm{TN}$ and $\mathrm{TP}$ instead of individual components is used to overcome differences between model outputs and observed 
data. The soil denitrification and aquatic degradation rate parameter in the reservoir and riverine water quality component of SWAT were calibrated.

The simulated and observed riverine TN and TP loads for the MORB outlet locations are shown in Fig. 14. Simulated temporal patterns for TN and TP follow the general trend of the observed data with some over-predictions for TN and TP. The monthly variability of riverine TN and TP loads are accurately simulated. It can be seen in these figures that the highest nutrient loads in the time series correspond to the rainfall events. The high load dissipates quickly. The trend components of the time series do not show any significant long-term upward trend for any of the major tributaries irrespective of the magnitude and duration of the riverine $\mathrm{TN}$ and TP loads during individual years. This shows that the potential for long-term accumulation of TN and TP in Missouri river is very low.
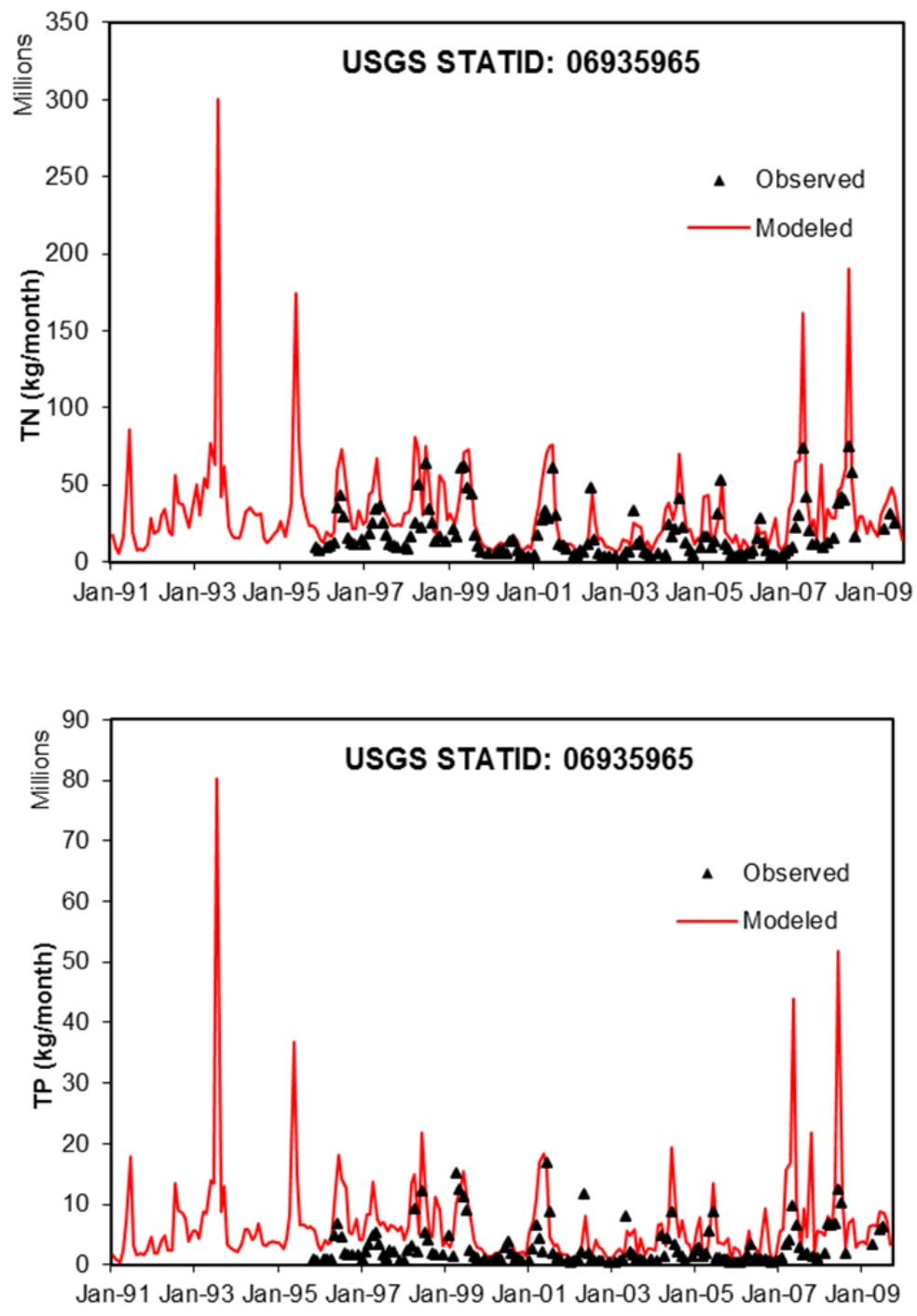

FIGURE 14 Time series plots of observed and modeled monthly riverine TN (top) and TP (bottom) loads over the calibration and validation periods. 


\section{ANALYSIS OF RIVERINE SEDIMENT AND NUTRIENT EXPORTS FROM MORB TRIBUTARIES}

Model performance statistics and graphical plots reveal that baseline SWAT model was effective in capturing watershed hydrology and capable of estimating riverine sediment and nutrient exports in the MORB. To compare riverine sediment and nutrient loads across the basin, the mainstem Missouri River is divided into four reaches: Upper, Middle, Lower Middle, and Lower Missouri River (Fig. 2). There are three major tributaries of the Missouri River including Yellowstone, Platte, and Kansas. The Yellowstone River contributes the largest volume of water of all the tributaries of the Missouri River. Long-term mean annual riverine loads were then estimated by using SWAT. For three major tributaries and the Upper Missouri River, their loads are presented as the loads in the river reach transported to the reach outlet after accounting for the effects of in-stream processes. Riverine sediment and nutrient exports from the Middle, Lower Middle, and Lower Missouri River reaches include sub-basins draining directly to a given reach and all of the upstream sub-basins draining to that reach. The Lower Missouri river loads include all of the sub-basins draining to the Missouri River and are ultimately delivered to the Mississippi River.

Modeled riverine sediment and nutrient loads are summarized for the major tributaries and main stem Missouri River reaches. The simulation results from SWAT model are summarized in Table 8 in terms of riverine TSS, TN, and TP loads, reported as the annual average for three base years of 2006 to 2008. Loads and yields from each tributary outlet are also illustrated in Fig. 14.

TABLE 8 Summary of riverine sediment and nutrient export loads.

\begin{tabular}{llll}
\hline Tributary or River Reach & TSS Load (ton/yr) & TN Load $(\mathrm{kg} / \mathrm{yr})$ & TP Load $(\mathrm{kg} / \mathrm{yr})$ \\
\hline & & & \\
Upper Missouri & $9 . \mathrm{E}+05$ & $2 . \mathrm{E}+07$ & $5 . \mathrm{E}+06$ \\
Yellowstone & $1 . \mathrm{E}+07$ & $2 . \mathrm{E}+07$ & $3 . \mathrm{E}+06$ \\
Middle Missouri & $2 . \mathrm{E}+07$ & $2 . \mathrm{E}+08$ & $4 . \mathrm{E}+07$ \\
Platte & $2 . \mathrm{E}+07$ & $7 . \mathrm{E}+07$ & $2 . \mathrm{E}+07$ \\
Lower Middle Missouri & $4 . \mathrm{E}+07$ & $3 . \mathrm{E}+08$ & $8 . \mathrm{E}+07$ \\
Kansas & $8 . \mathrm{E}+06$ & $5 . \mathrm{E}+07$ & $9 . \mathrm{E}+06$ \\
Lower Missouri & $6 . \mathrm{E}+07$ & $4 . \mathrm{E}+08$ & $1 . \mathrm{E}+08$ \\
\hline
\end{tabular}

Loads and yields of sediment, TN and TP varied considerably among the major tributaries of the MORB. Because of the large size of the Middle Missouri River sub-basin and the relatively high inputs in the Lower Missouri River sub-basin, the largest TN and TP loads were in these two sub-basins, although the TP loads from the Platte, Lower Middle Missouri, and Kansas River sub-basins were nearly as large as the TP load from the Middle Missouri River sub-basin (Fig. 15). The smallest loads were from the Upper Missouri and Yellowstone River sub-basins where inputs from all sources are low when compared with inputs from the other sub- 
basins. This is likely attributable to the large pasture and range land in this area where fertilizer input is relatively low.

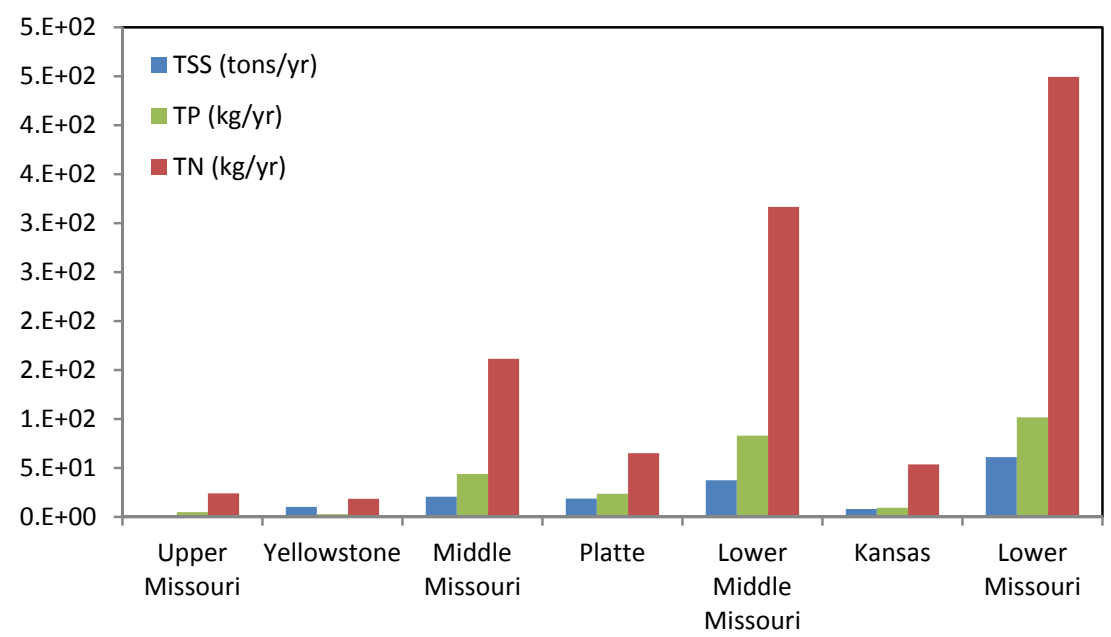

FIGURE 15 Simulated annual mean riverine sediment and nutrient loads for the period 2006-2008. Note: tons = metric tons

The total load delivered to the Mississippi River from the MORB was approximately $6.1 \times 10^{7} \mathrm{ton} / \mathrm{yr}$ for TSS, $4.5 \times 10^{8} \mathrm{~kg} / \mathrm{yr}$ for TN and $1.0 \times 10^{8} \mathrm{~kg} / \mathrm{yr}$ for TP (Table 8). Of these loads, the largest percentage was contributed by the Middle Missouri and Lower Missouri River sub-basins (28.4 and $29.1 \%$ for TN, respectively; 18.6 and $38.7 \%$ for TP, respectively), whereas the smallest percentage was contributed by the Upper Missouri and Yellowstone sub-basins $(0.2$ and $0.4 \%$ for TN, respectively; $0.1 \%$ each for TP), as also indicated in Fig. 15.

\section{SUMMARY AND CONCLUSIONS}

The SWAT model was applied to the MORB to simulate hydrology, sediment, and nutrients. This study used the best available data including highly detailed weather records distributed across the watershed and land cover classification. The model was calibrated for a period of 13 years (1990-2002) and then followed by a validation period of seven years (2003-2009). Monthly and annual ENS, R ${ }^{2}$, PBIAS, and RSR values were determined for hydrology calibration and validation for all 19 stream flow gaging station locations and illustrate the capability of SWAT for predicting hydrology; calibration ENS and $\mathrm{R}^{2}$ values are greater than 0.5 for all locations and time steps with the exception of few stations while PBIAS results indicate satisfactory to very good performance for all locations. Results generated from the SWAT model for nitrogen load, phosphorus loads, TSS loads, and flow at sub-basin and tributary levels, on average, were not seriously biased. SWAT accurately predicted overall average loads for all USGS gage locations during both the calibration and validation time periods. Thus, when accompanied by acknowledgment of model uncertainty, we have confidence 
that the SWAT model will be readily useful for future studies in this region to predict changes in average sediment and nutrient load in response to new crop production, implementation of land management practices, and climate changes.

\section{REFERENCES}

Arnold, J.G., R. Srinivasan, R.S. Muttiah, and J.R. Williams, 1998. Large-area hydrologic modeling and assessment: Part I. Model development. Journal of the American Water Resources Association 34(1): 73-89.

Arabi, M., J.R. Frankenberger, B.A. Engel, and J.G. Arnold. 2008. Representation of Agricultural Conservation Practices with SWAT. Hydrological Processes. 22: 3042-3055.

Bagnold, R.A. 1977. Bed-load transport by natural rivers. Water Resources Research 13:303312.

Baker, N.T., 2011, Tillage practices in the conterminous United States, 1989-2004-Datasets Aggregated by Watershed: U.S. Geological Survey Data Series 573, 13 p.

Baumgart, P.D. 2005. Lower Green Bay and Lower Fox Tributary Modeling Report. Prepared for Oneida Tribe of Indians of Wisconsin and Green Bay Remedial Action Plan Science and Technical Advisory Committee.

Brown, J.B., L.A. Sprague, and J.A. Dupree, 2011. Nutrient Sources and Transport in the Missouri River Basin, With Emphasis on the Effects of Irrigation and Reservoirs. Journal of the American Water Resources Association 47(5): 1034-1060.

Brown, L.C., and Barnwell, T.O. (1987). The Enhanced Stream Water Quality Models QUAL2E and QUAL2E-UNCAS. EPA/600/3-87-007, U.S. Environmental Protection Agency, Athens, GA, 189 pp.

Demissie, Y., E. Yan, and M. Wu. 2012. Assessing Regional Hydrology and Water Quality Implications of Large-Scale Biofuel Feedstock Production in the Upper Mississippi River Basin, Environ. Sci. Technol., 46, 9174-9182.

DiLuzio, M., R. Srinivasan, and J.G. Arnold. 2002. Integration of watershed tools and SWAT model into BASINS. J of American Water Resources Association 38(4): 1127-1141.

Donner, S.D and D. Scavia. 2007. How climate controls the flux of nitrogen by the Mississippi River and the development of hypoxia in the Gulf of Mexico. Limnol. Oceanogr. 52(2): 856-861. 
Gassman, P.W., Reyes, M.R., Green, C.H., and Arnold, J.G., 2007, The soil and water assessment tool - historical development, applications, and future research directions: Transactions of the American Society of Agricultural and Biological Engineers (ASABE), 50(4); 1211-1250.

Heimann, D.C., P. P. Rasmussen, T. L. Cline, L. M. Pigue, and H. R. Wagner. 2010. Characteristics of Sediment Data and Annual Suspended-Sediment Loads and Yields for Selected Lower Missouri River Mainstem and Tributary Stations, 1976-2008. U.S. Geological Survey Data Series Report 530, 58 pp.

Meade, R. H., 1995, Contaminants in the Mississippi River, 1987-92: U.S. Geological Survey Circular 1133, 140 p.

Meade, R.H., and J.A. Moody, 2010, Causes for the decline of the suspended-sediment discharge in the Mississippi River System, 1940-2007: Hydrological Processes 24(1): 35-49.

Mississippi River/Gulf of Mexico Watershed Nutrient Task Force. 2001. Action Plan for Reducing, Mitigating, and Controlling Hypoxia in the Northern Gulf of Mexico (www.epa.gov/msbasin/actionplan.htm).

Mississippi River/Gulf of Mexico Watersheds Nutrient Task Force, 2008. Gulf Hypoxia action plan 2008. http://water.epa.gov/type/watersheds/named/msbasin/upload/

2008_8_28_msbasin_ghap2008_update082608.pdf. Accessed Oct. 10, 2013.

Mississippi River/Gulf of Mexico Watersheds Nutrient Task Force, 2013. Assessing Progress Made since 2008. http:/water.epa.gov/type/watersheds/named/msbasin/upload/ hypoxia_reassessment_508.pdf. Accessed Oct. 10, 2013.

Moriasi, D.N., Arnold, J.G., Van Liew, M.W., Binger, R.L., Hermel, R.D., and Veith, T. 2007. Model evaluating guidelines for systematic quantification of accuracy in water simulations. Transactions of $A S A B E, 50(3), 885-900$.

Nakagaki, Naomi, and Wolock, D.M., 2005, Estimation of agricultural pesticide use in drainage basins using land cover maps and county pesticide data: U.S. Geological Survey Open-File Report 2005-1188.

National Research Council (NRC), 2011. Missouri River Planning: Recognizing and Incorporating Sediment Management. Washington, DC: The National Academies Press.

Neitsch, S.L., J.G. Arnold, J.R. Kiniry, and J.R. Williams. 2011. Soil and Water Assessment Tool Theoretical Documentation, version 2009. Grassland, Soil and Water Research Laboratory, Agricultural Research Service, Blackland research Center, Texas AgriLife research, Temple, TX.

Rabalais, N. N., R. E. Turner and D. Scavia. 2002. Beyond science into policy: Gulf of Mexico hypoxia and the Mississippi River. BioScience 52: 129-142. 
Santhi, C., J.G. Arnold, J.R. Williams, W.A. Dugas, R. Srinivasan, and L. Hauck, 2001a. Validation of the SWAT model on a large river basin with point and nonpoint sources. Journal of the American Water Resources Association 37: 1169-1188.

Santhi, C., J.G. Arnold, J.R. Williams, L.M. Hauck, and W.A. Dugas, 2001b. Application of a watershed model to evaluate management effects on point and nonpoint source pollution. Transactions of the ASAE 44(6): 1559-1570.

Sahu, M.K. and Gu, R. R. 2009. Modeling the effects of riparian zone and contour strips on stream water quality. Ecological Engineering, 35(2009), 1167-1177.

Scavia, D., Donnelly, K.A. 2007. Reassesing Hypoxia Forecasts for the Gulf of Mexico. Env. Sci. Technol. 41: 8111-8117.

Sprague, L.A., Clark, M.L., Rus, D.L., Zelt, R.B., Flynn, J.L., and Davis, J.V., 2006, Nutrient and Suspended-Sediment Trends in the Missouri River Basin, 1993-2003: U.S. Geological Survey Scientific Investigations Report 2006-5231, 80 p.

Sprague, L.A., R.M. Hirsch, and B.T. Aulenbach 2011. Nitrate in the Mississippi River and Its Tributaries, 1980 to 2008: Are We Making Progress? Environ. Sci. Technol., 2011, 45 (17): 7209-7216.

Turner, R.E., N.N. Rabalais and D. Justić. 2008. Gulf of Mexico hypoxia: Alternate states and a legacy. Environ. Sci. Technol., 42: 2323-2327.

Unger, P.W., and T.C. Kaspar. 1994. Soil compaction and root growth: a review. Agron. J. 86(5): 759-766.

U.S. Army Corps of Engineers (USACE), 2004. Missouri River Mainstem Reservoir System, Master Water Control Manual, Missouri River Basin. Reservoir Control Center, Northwestern Division, U.S. Army Corps of Engineers, Omaha, Nebraska.

USDA ERS. Manure Use for Fertilizer and for Energy, Report to Congress. Washington DC: USDA ERS; June 2009. 46 p.

USDOE, 2011. Biomass Multi-year Program, Nov. http://www1.eere.energy.gov/bioenergy/pdfs/ mypp_april_2011.pdf

USEPA, 2008. Gulf Hypoxia Action Plan 2008. Mississippi River Gulf of Mexico Watershed Nutrient Taskforce. http://water.epa.gov/type/watersheds/named/msbasin/index.cfm

Van Liew, M.W., and J. Garbrecht. 2003. Hydrologic simulation of the Little Washita River Experimental.

Watershed using SWAT. Journal of the American Water Resources Association 39(2): 413-426. Van Liew, M.W., J.G. Arnold, and D.D. Bosch, 2005. Problems and Potential of Autocalibrating a Hydrologic Model. Transactions of the ASAE 48(3): 1025-1040. 
Wetzel, R. G. 2001. Limnology: Lake and reservoir ecosystems, Academic, New York.

White, K.L., and I. Chaubey, 2005. Sensitivity Analysis, Calibration, and Validations for a Multisite and Multivariable SWAT Model. Journal of the American Water Resources Association 41(5):1077-1089.

Williams, J.R. and H.D. Berndt. 1977. Sediment yield prediction based on watershed hydrology. Transactions of the ASAE 20: 1100-1104.

Wu, M., Y. Demissie, and E. Yan. 2012, Assessing the Impact of Future Biofuel Scenario on Water Quality and Water Cycle Dynamics, Biomass \& Bioenergy, 41(2012)44-56. 


\section{APPENDIX A}

Observed and Modeled Time Series Plots of Annual and Monthly Averaged Flow for Nineteen Stations in the Missouri River Basin 

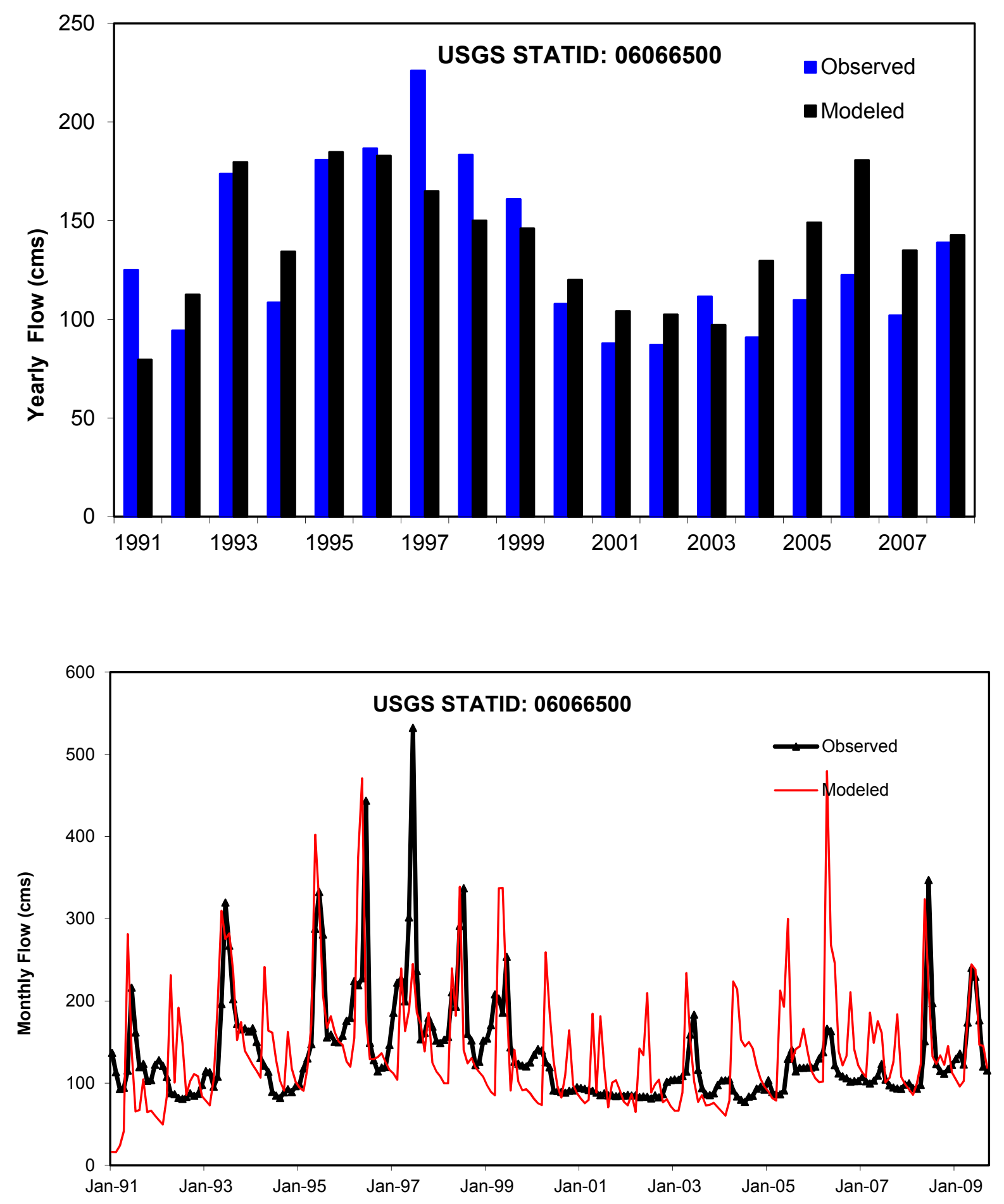

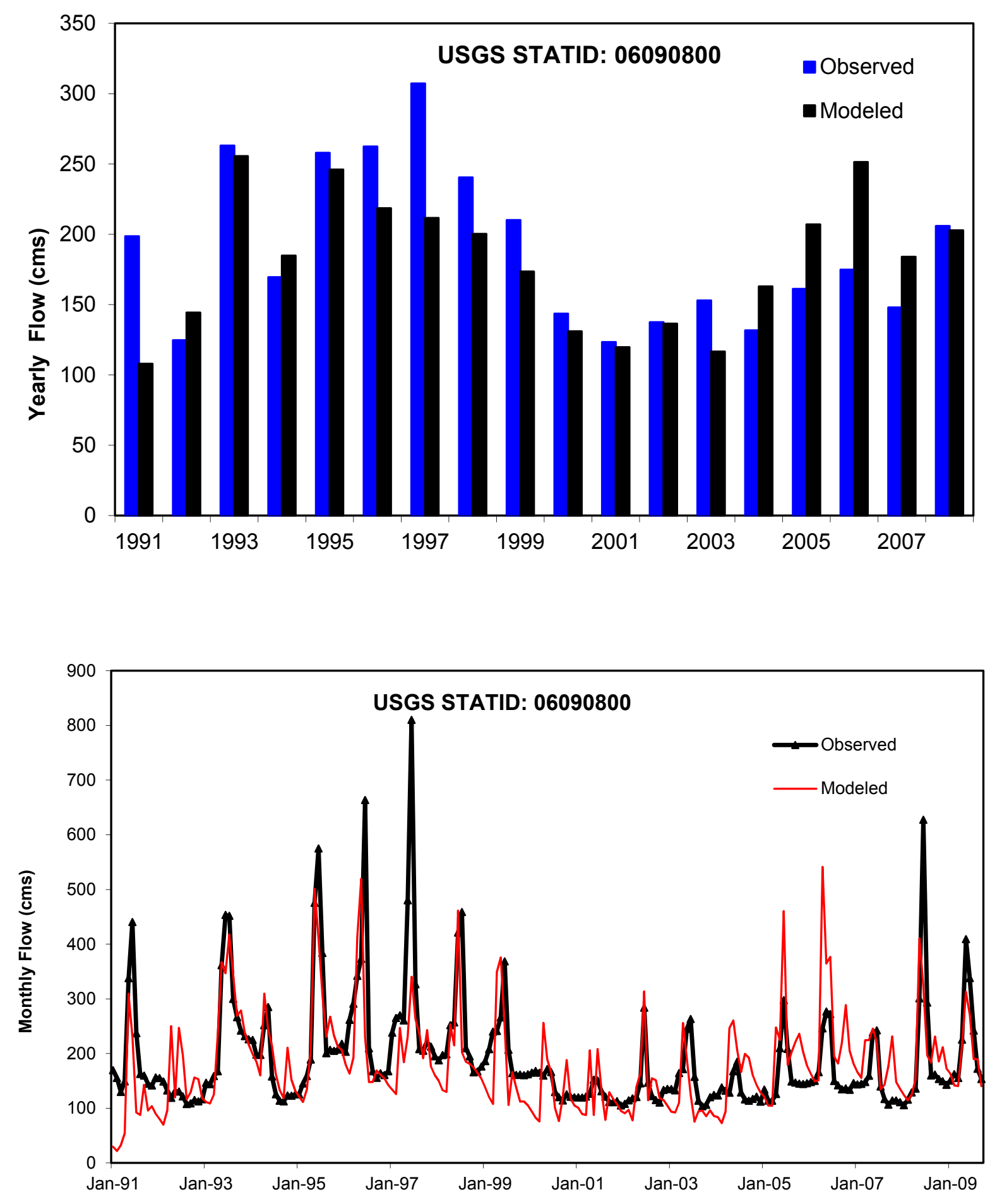

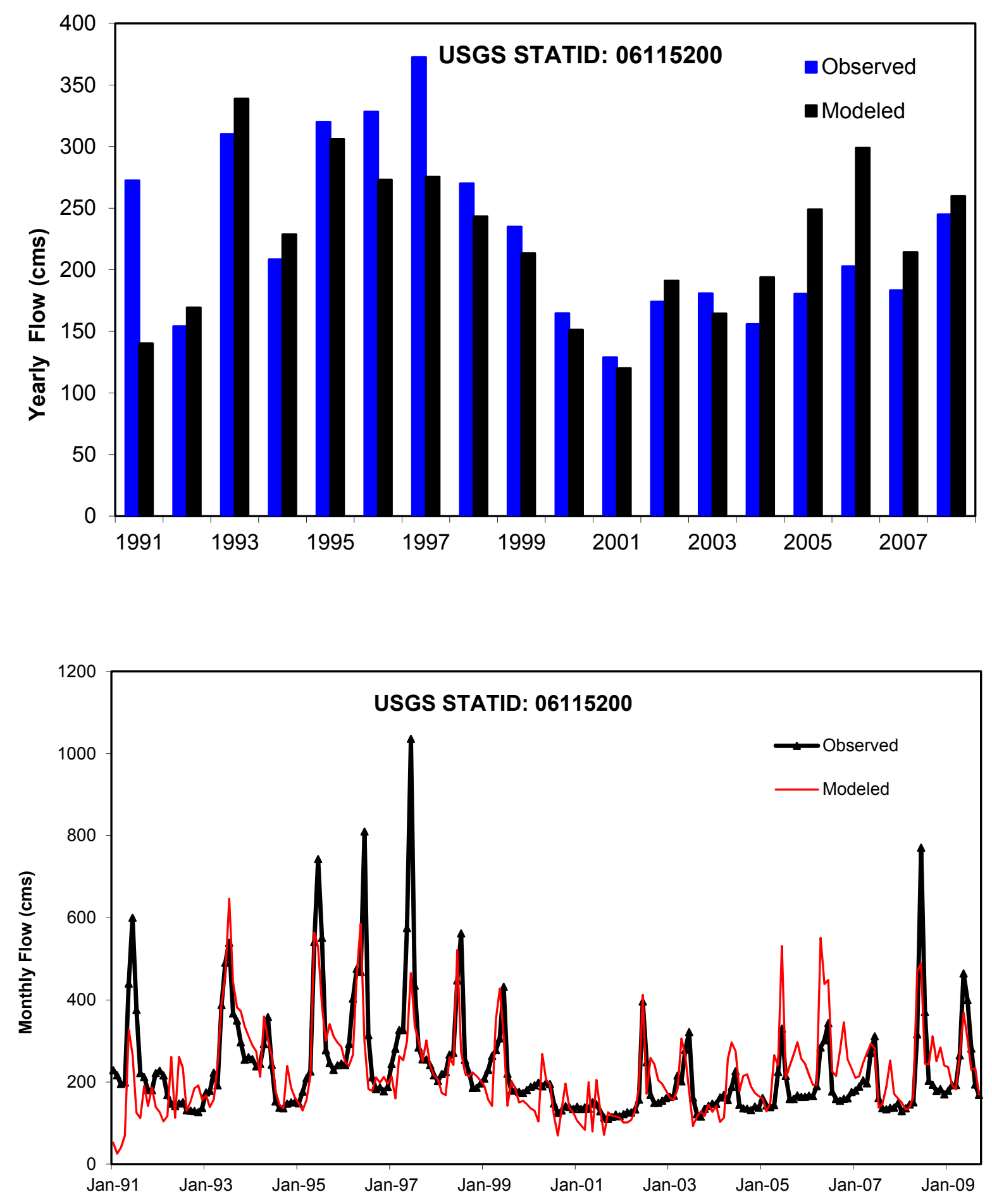

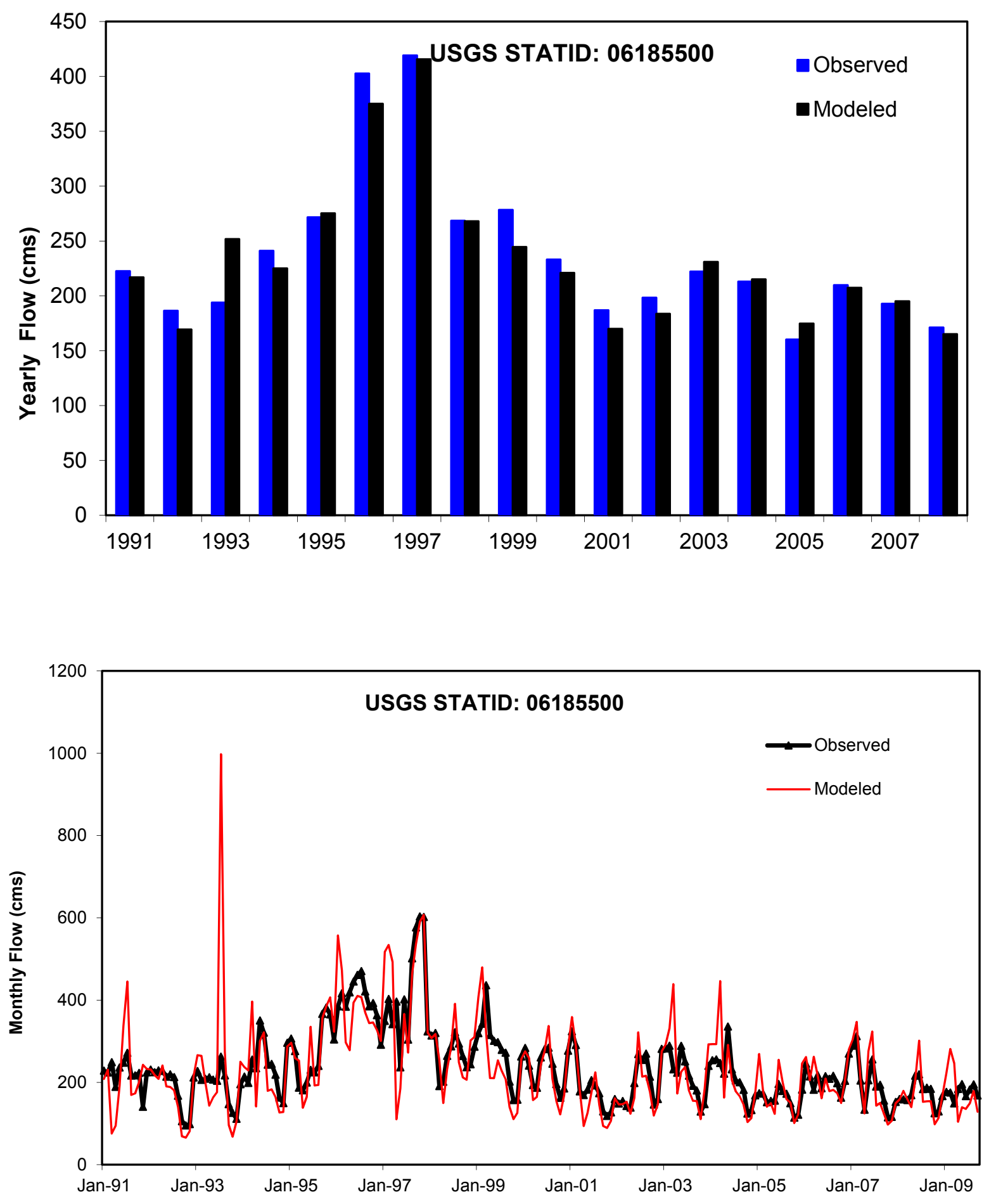

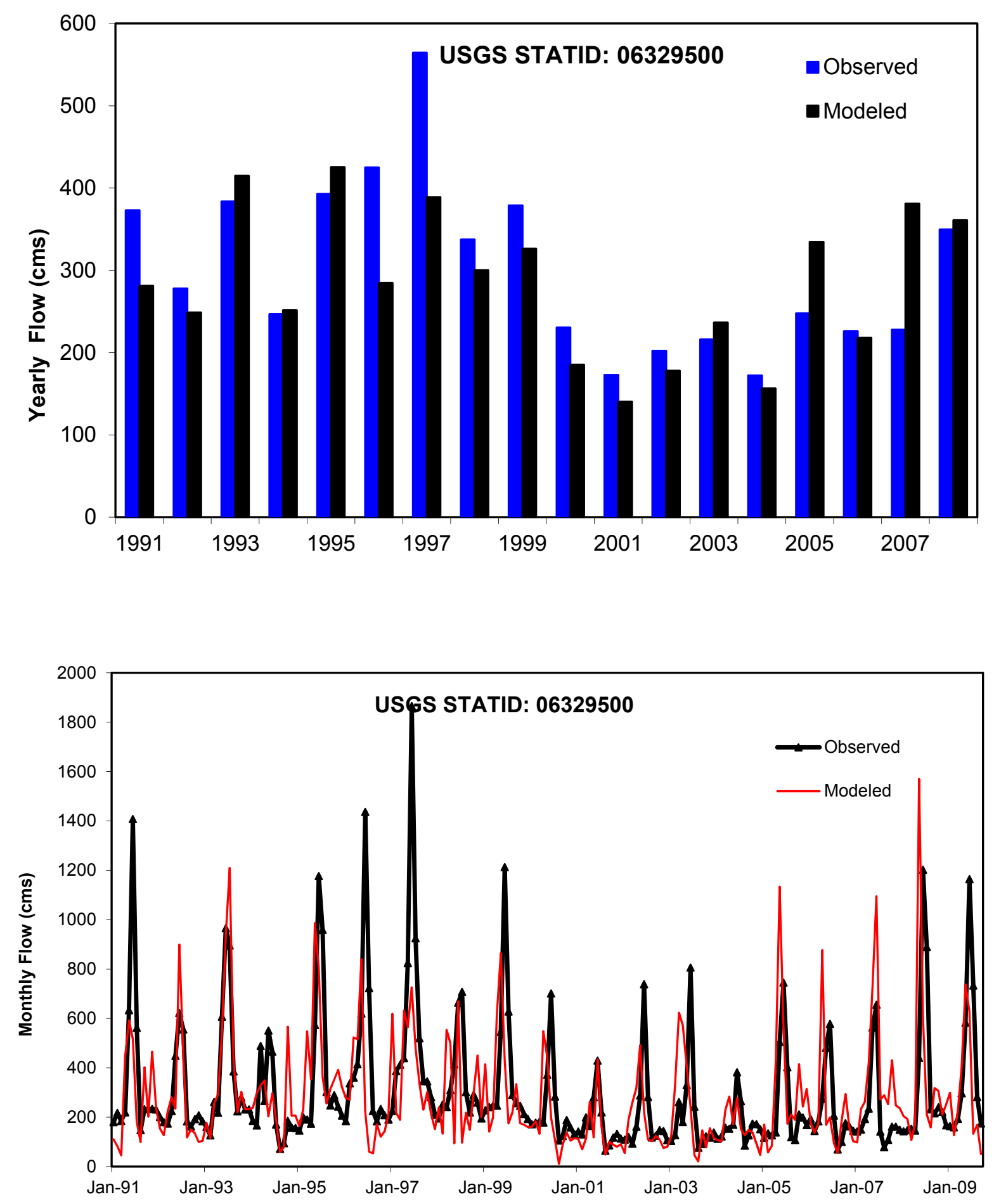

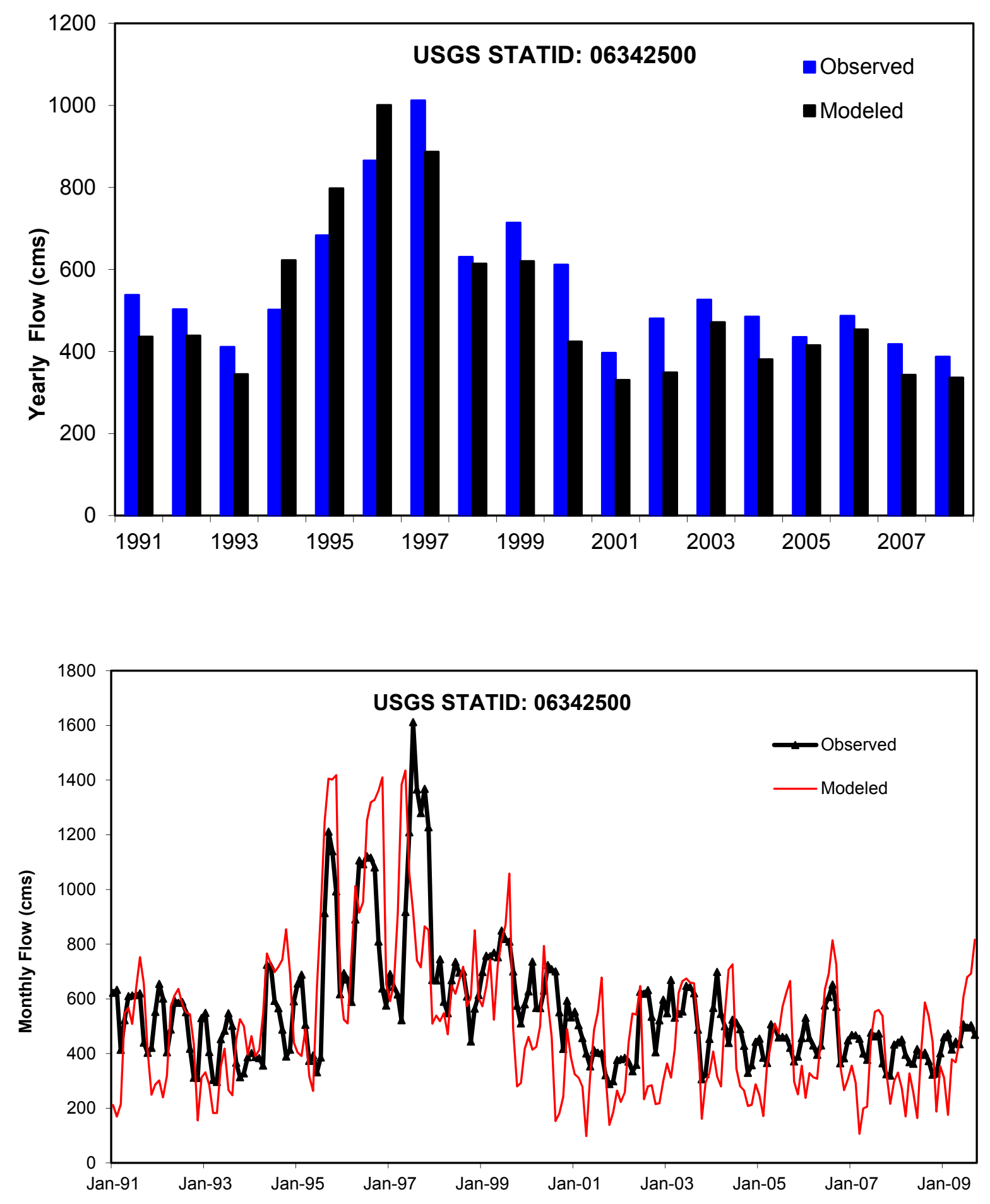

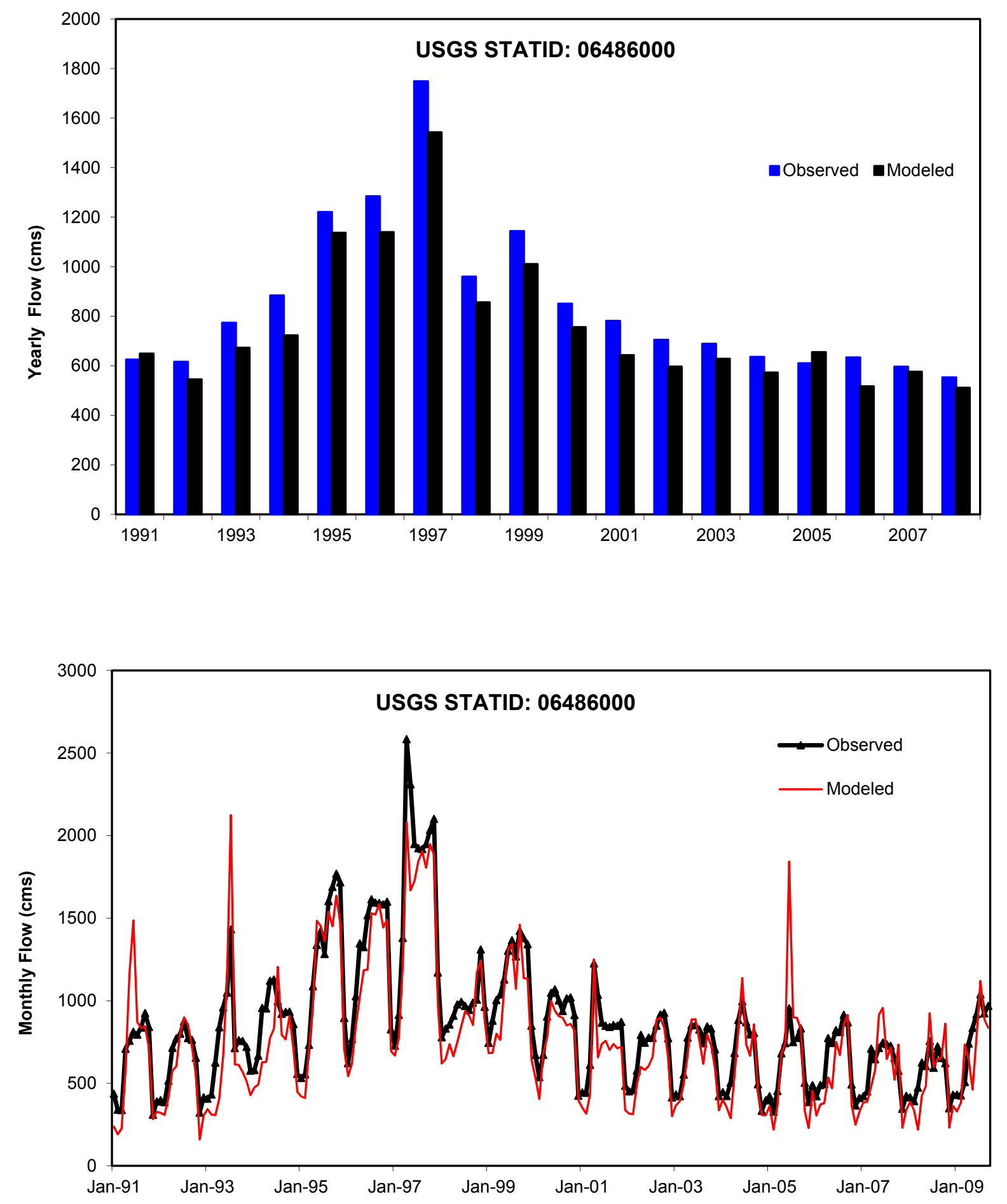

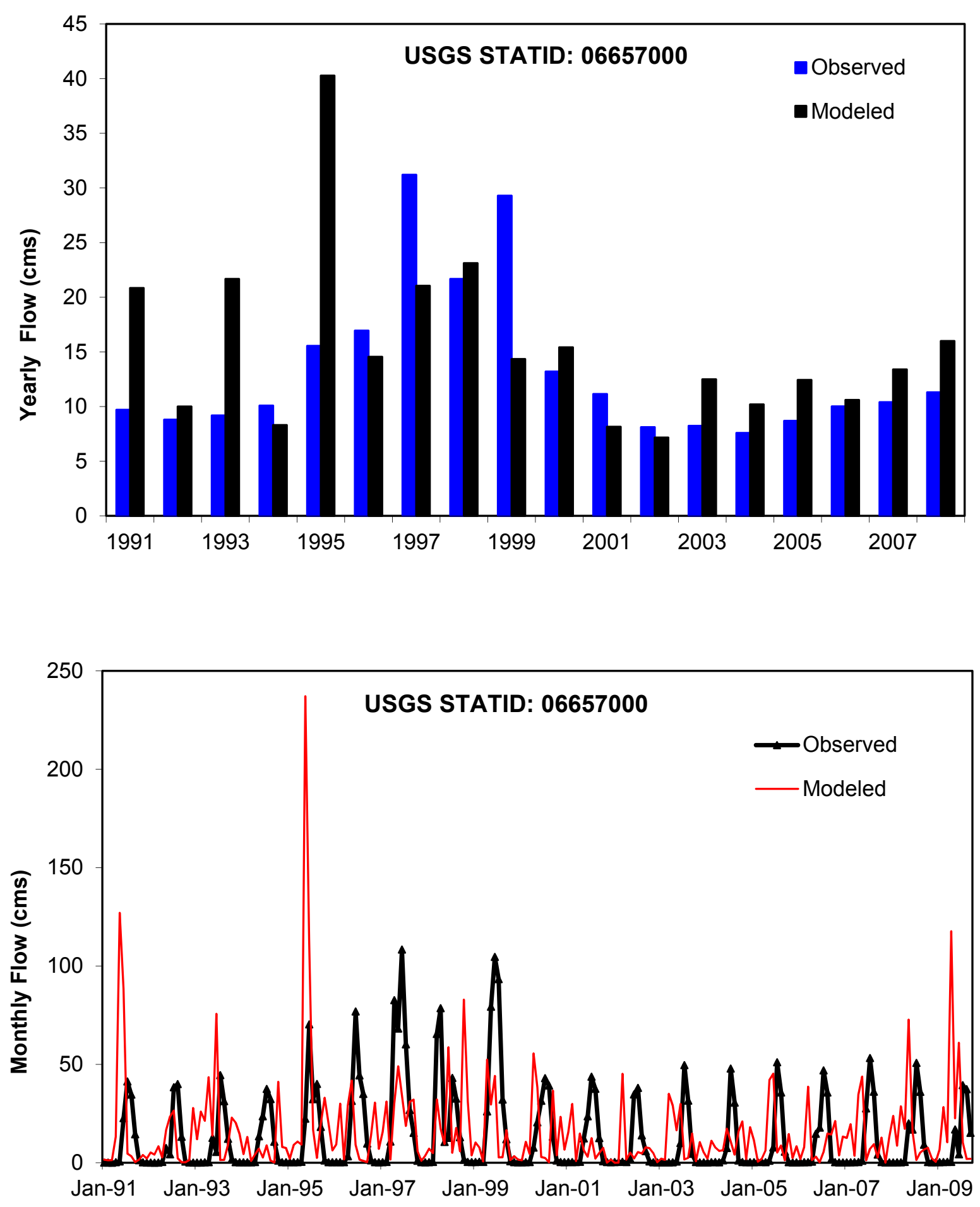

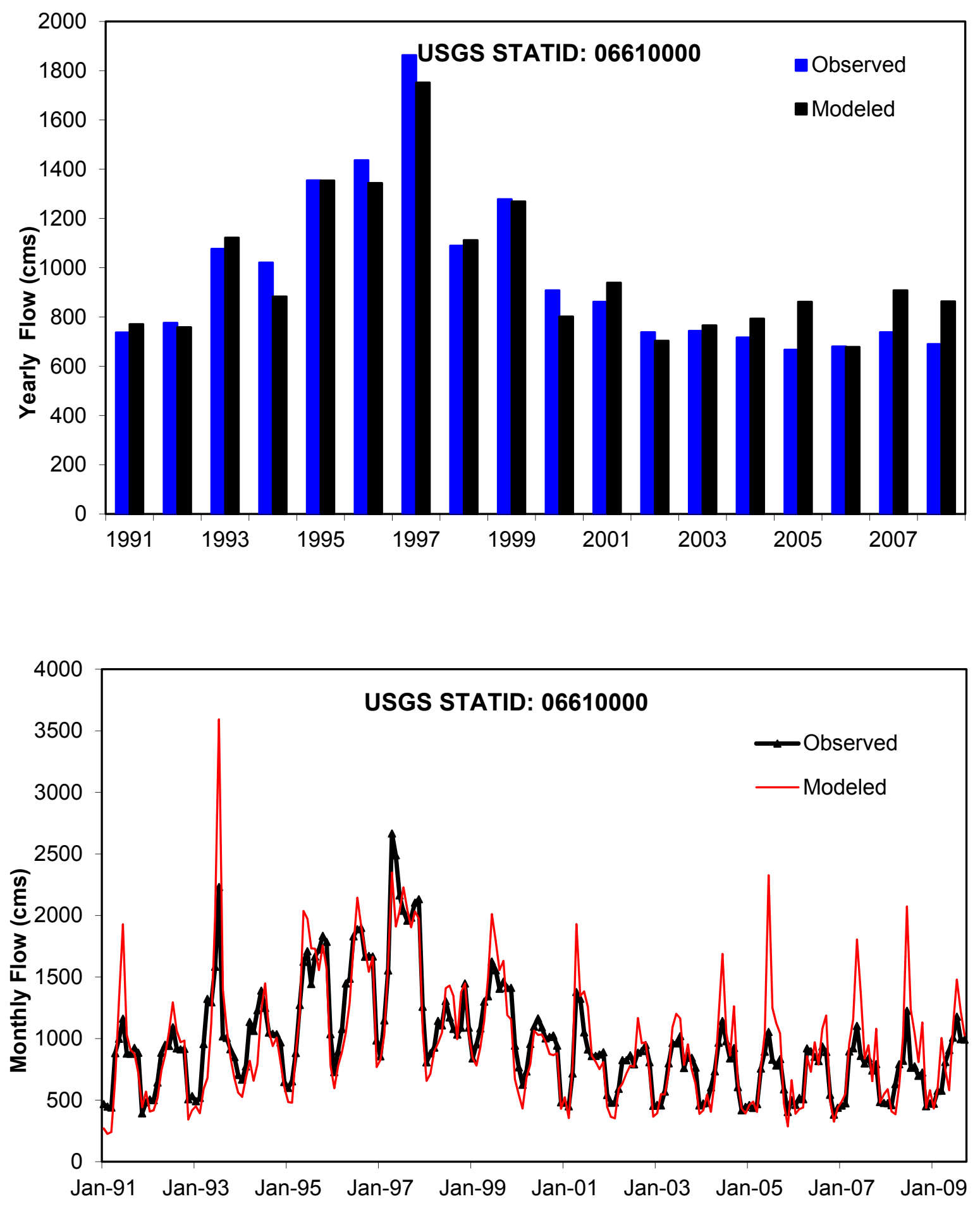

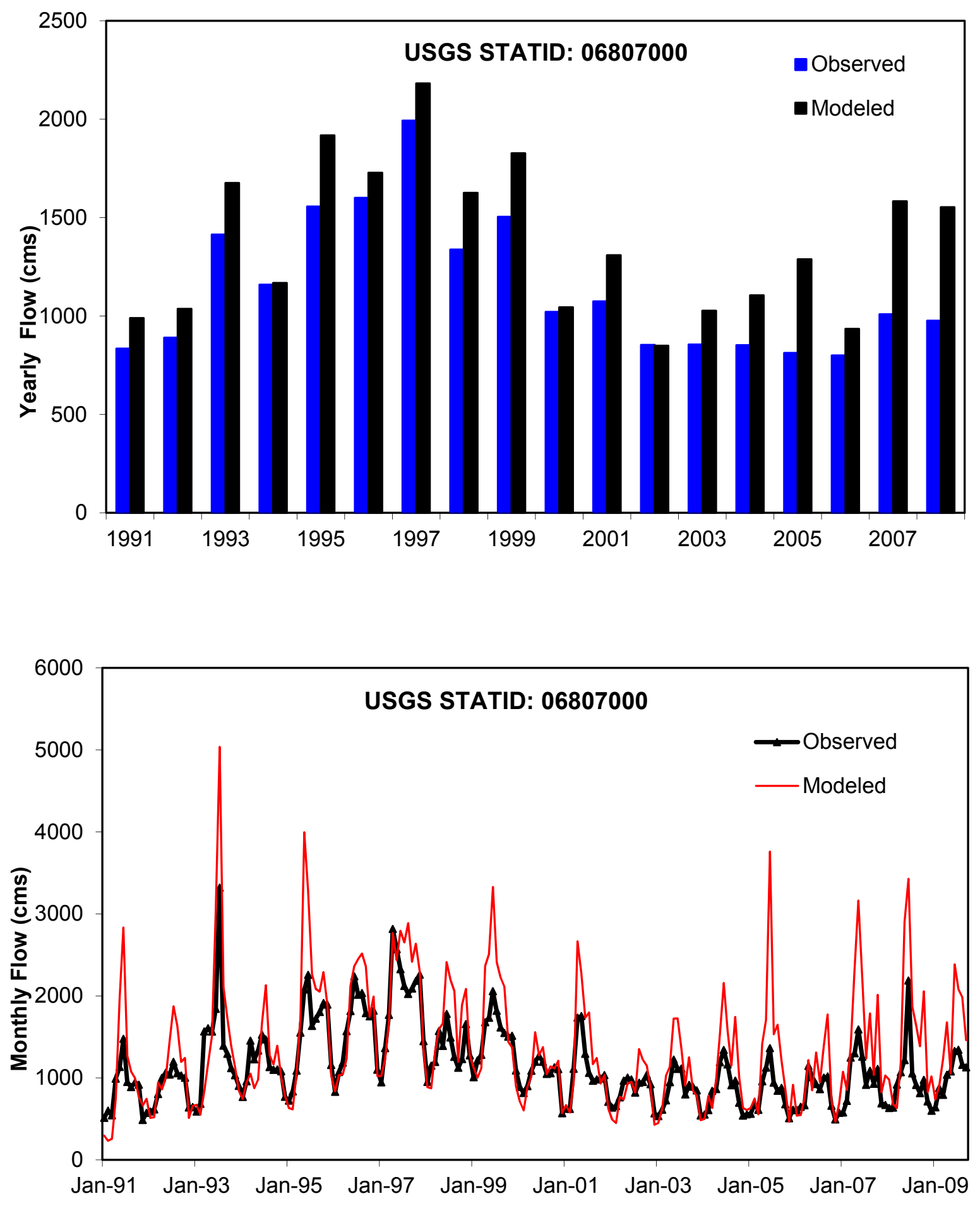

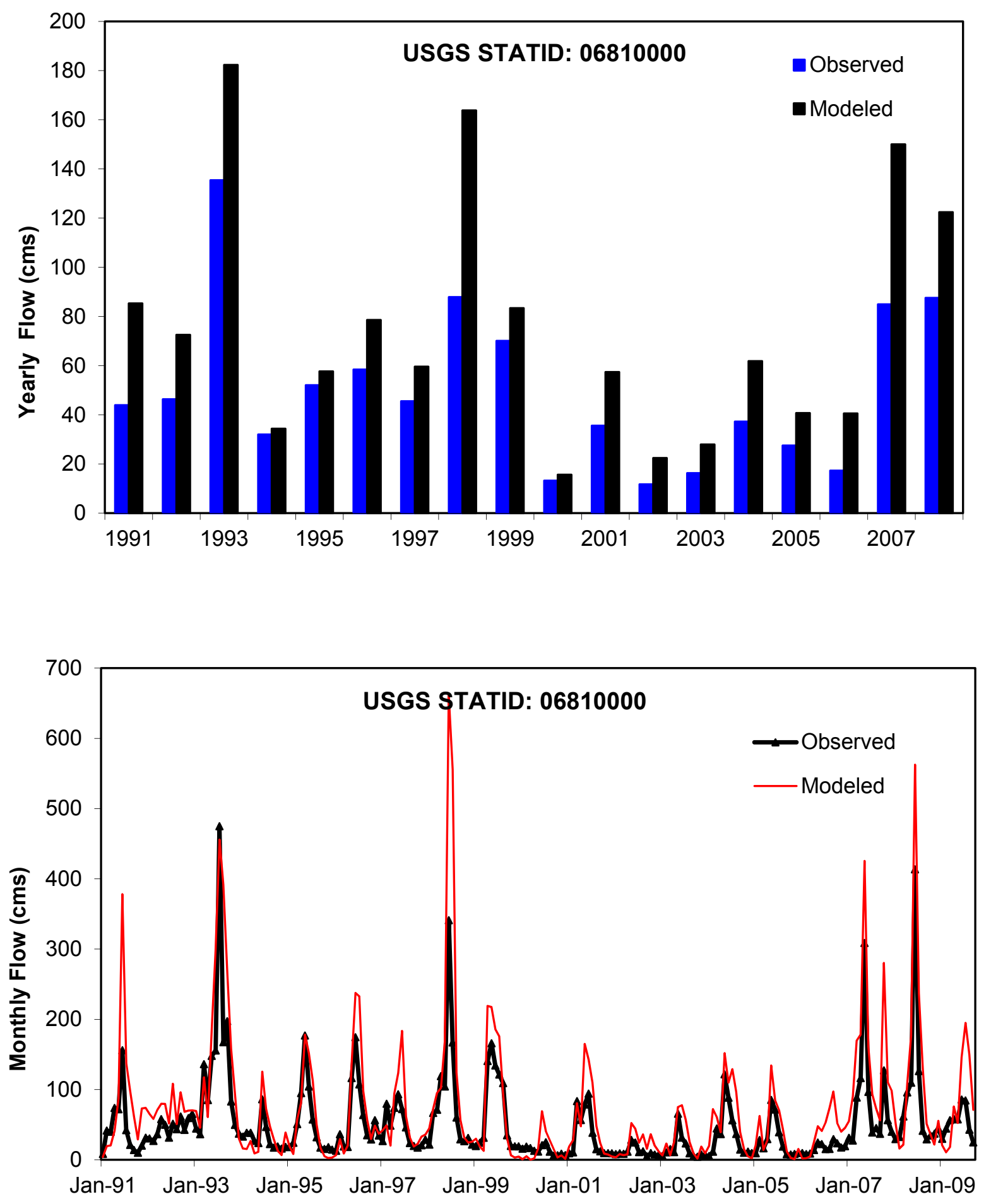

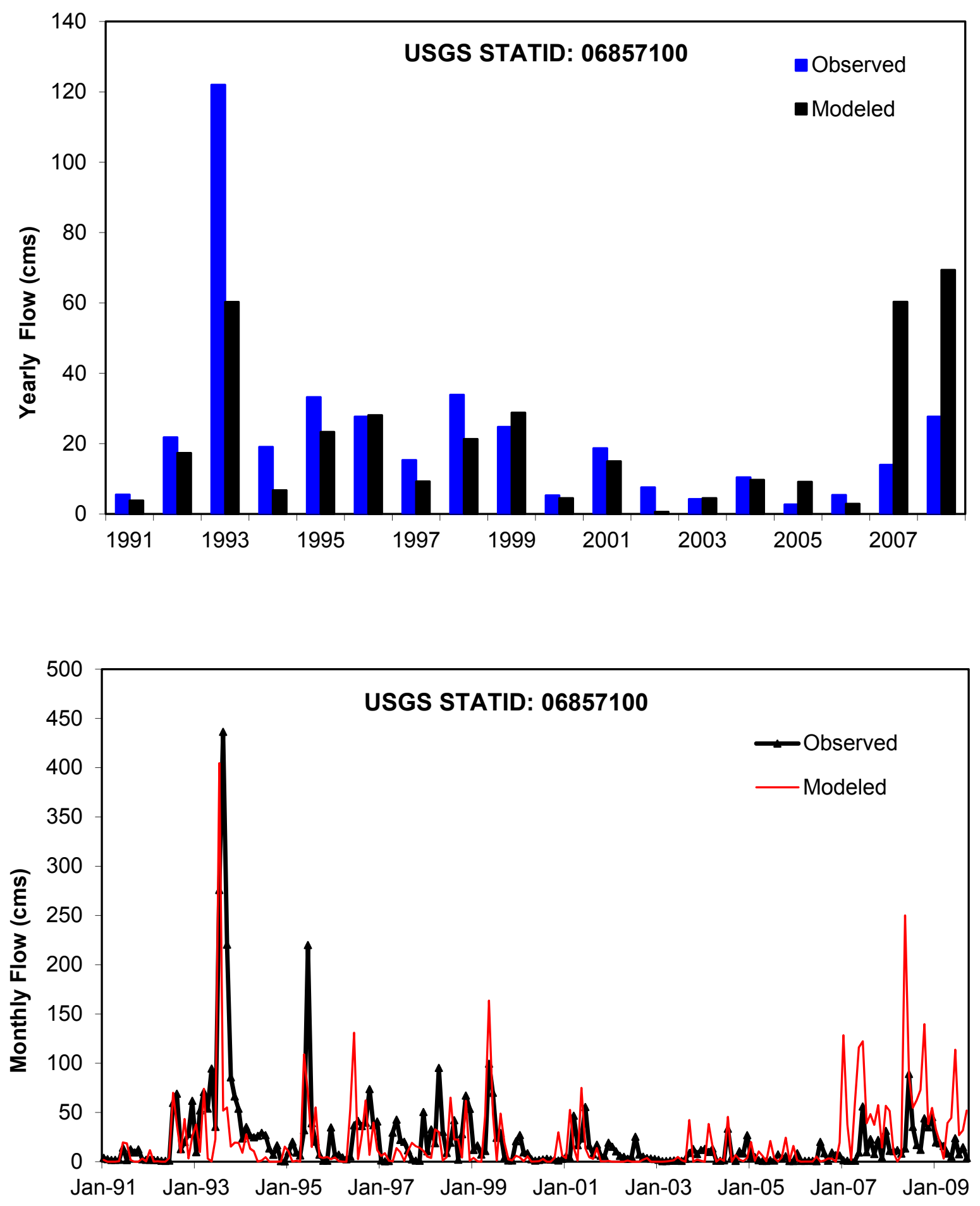

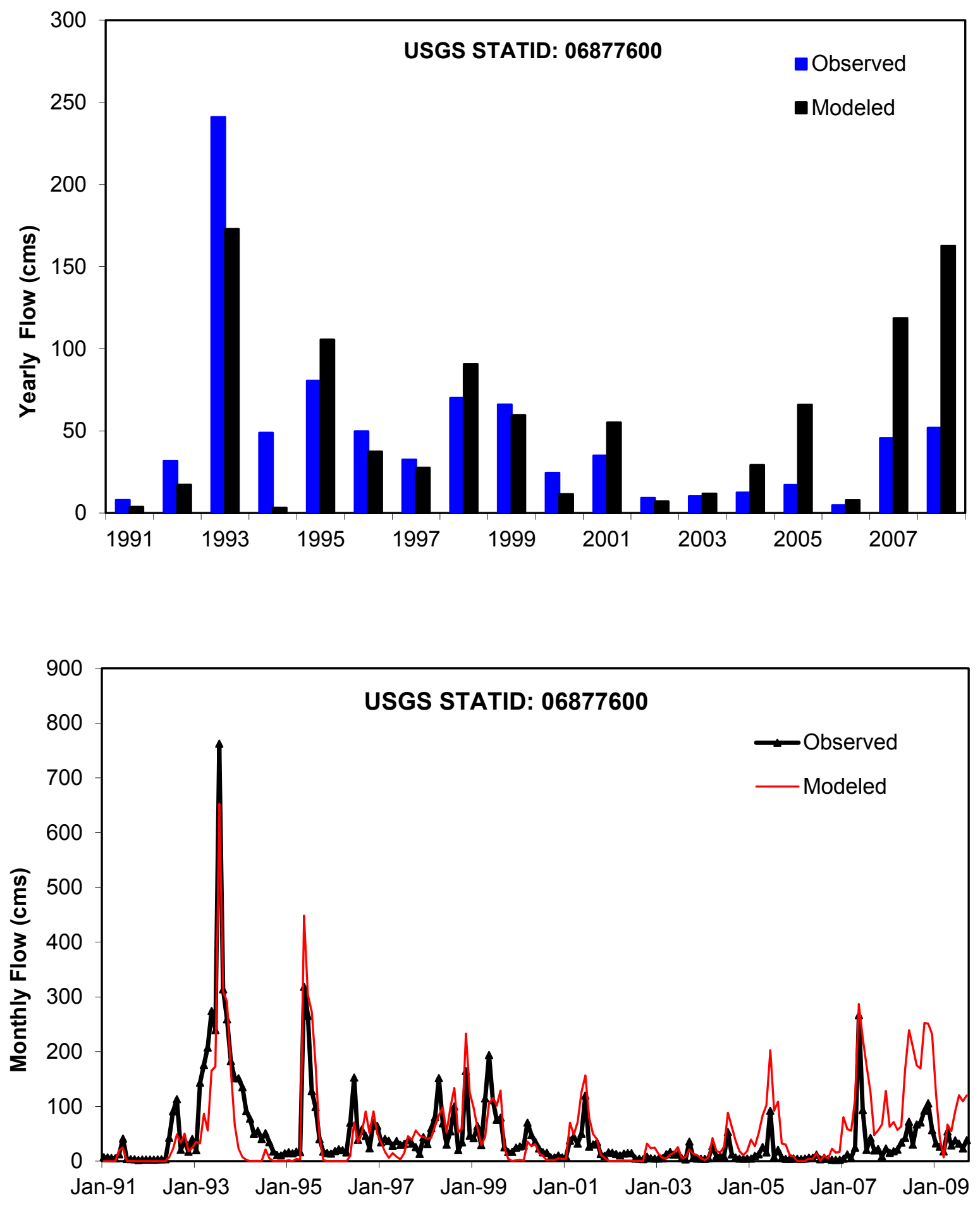

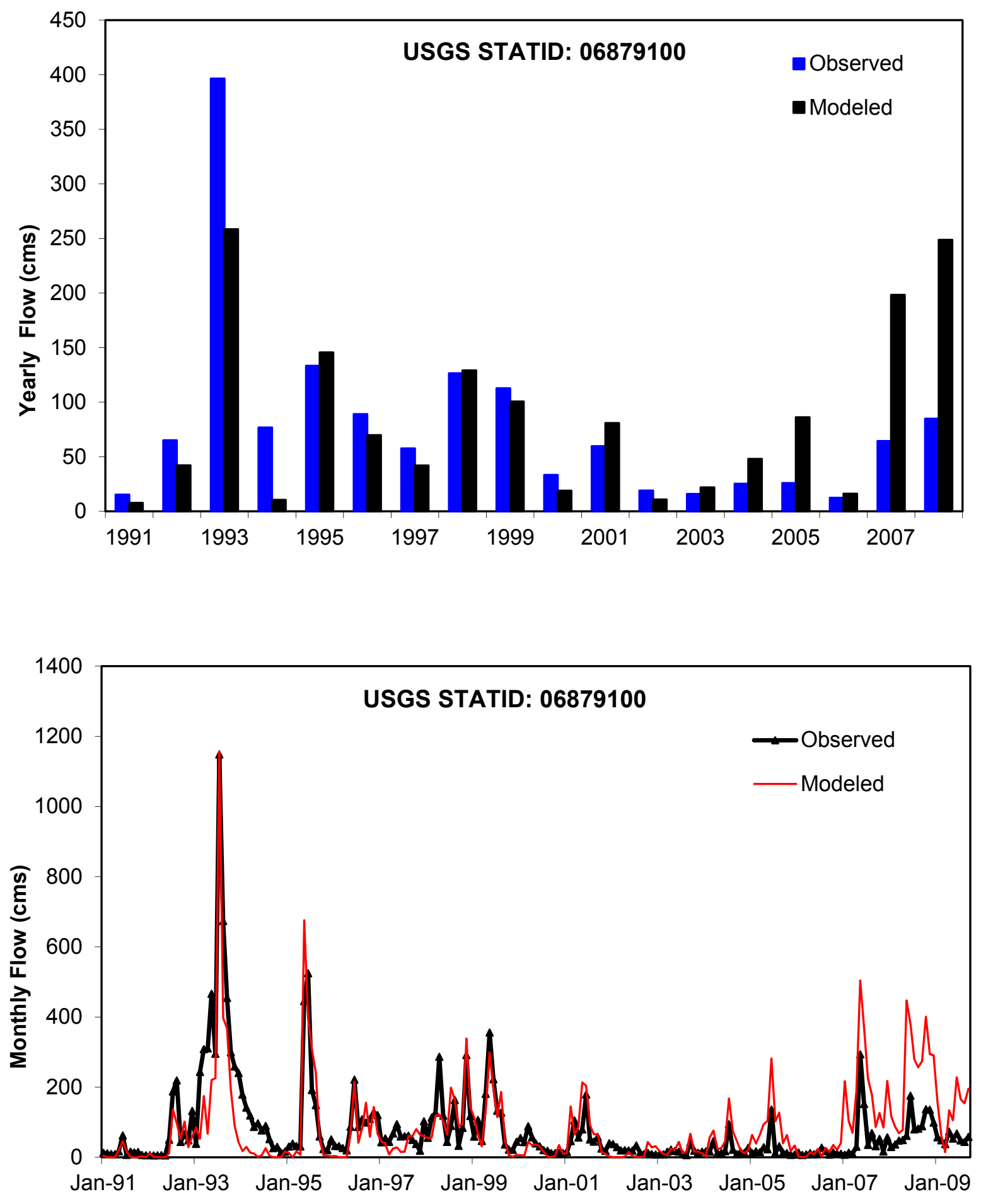

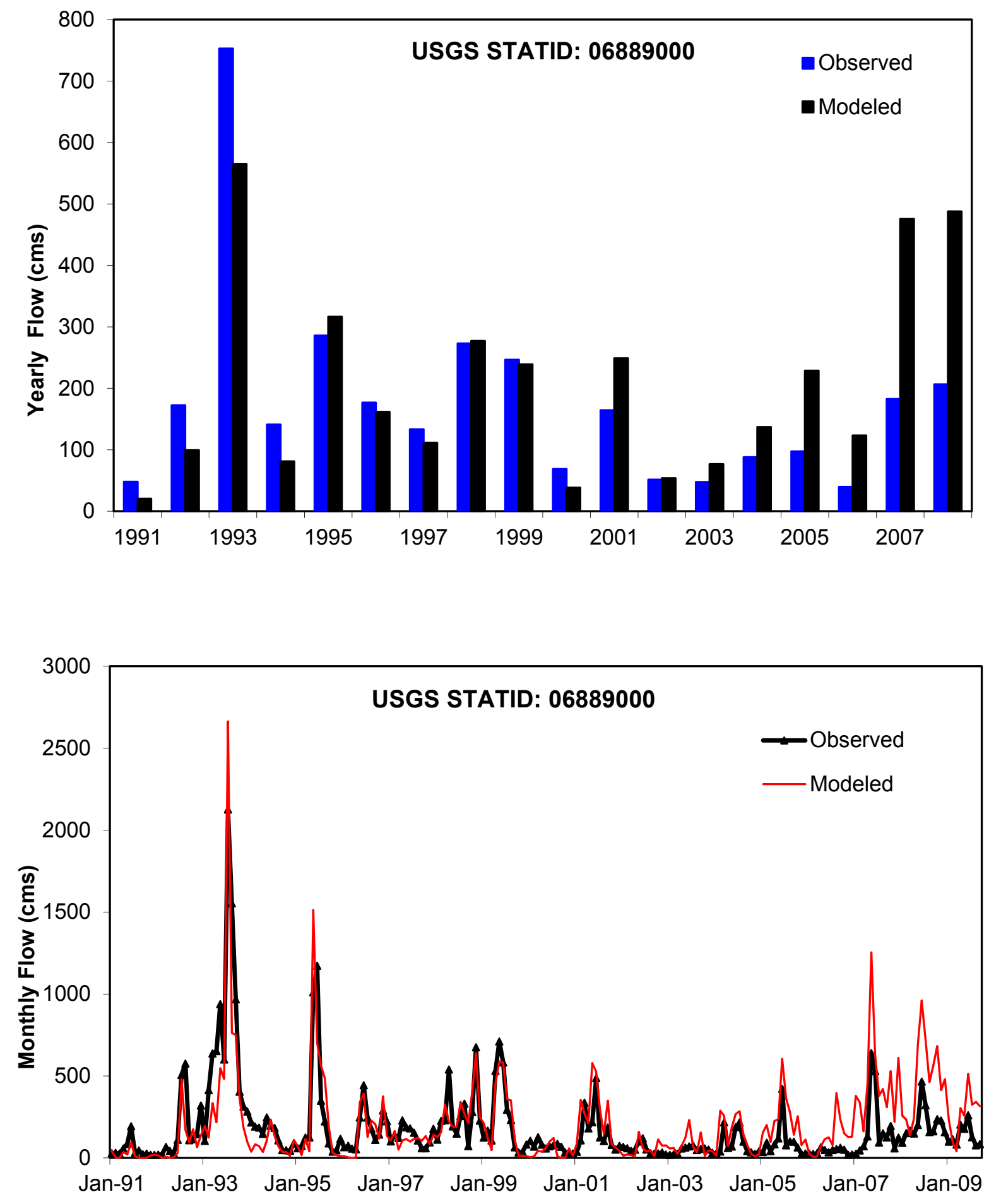

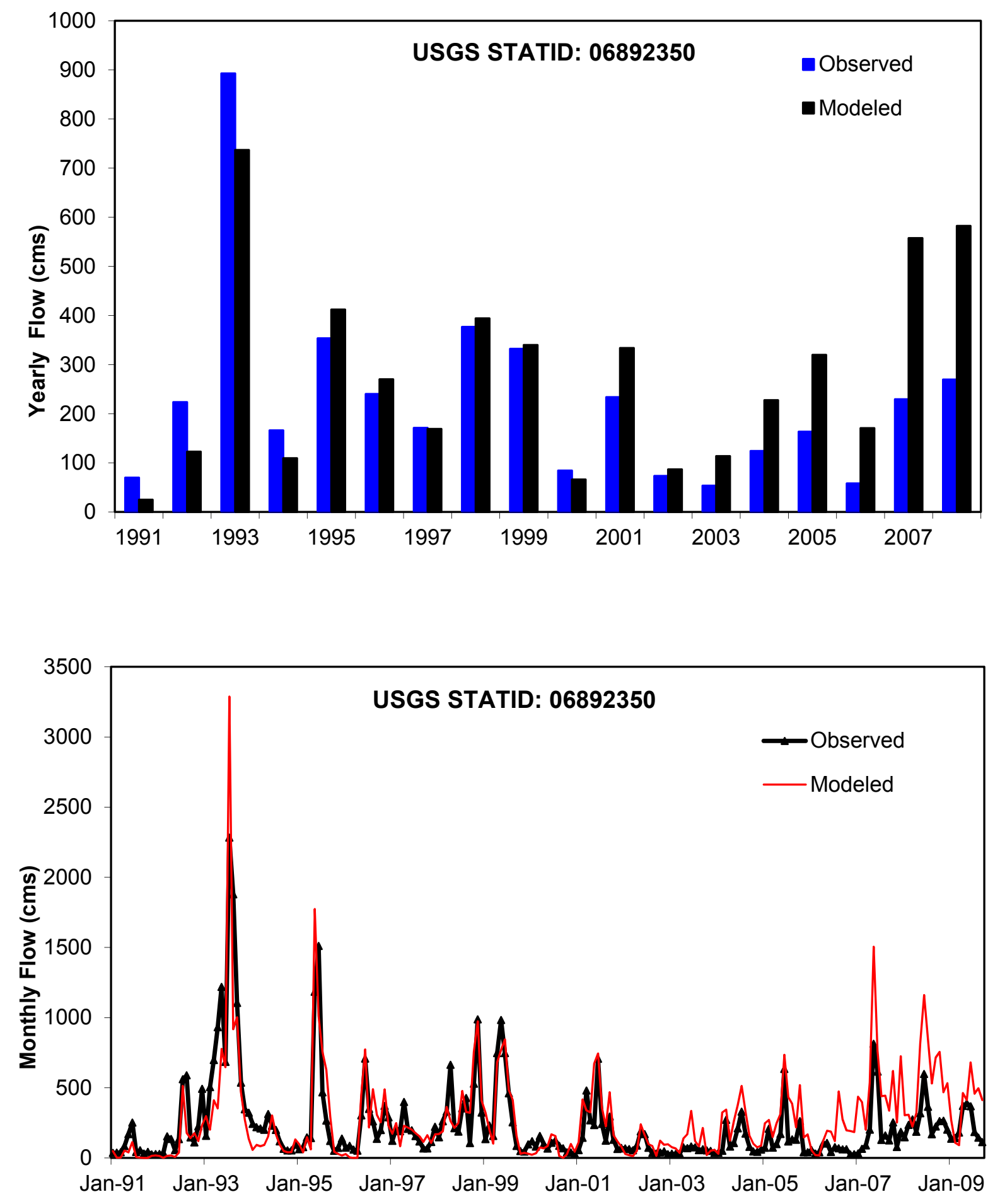

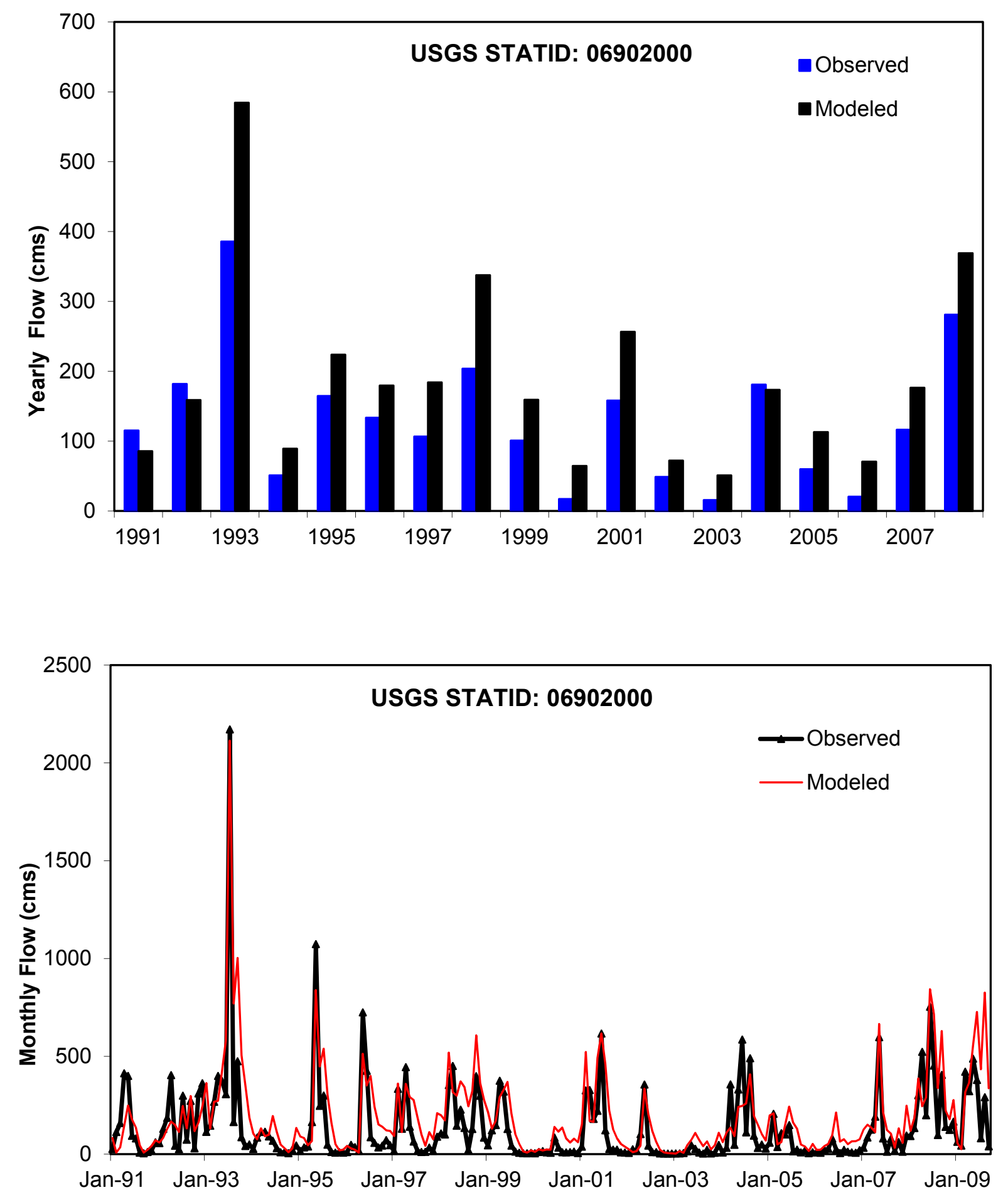

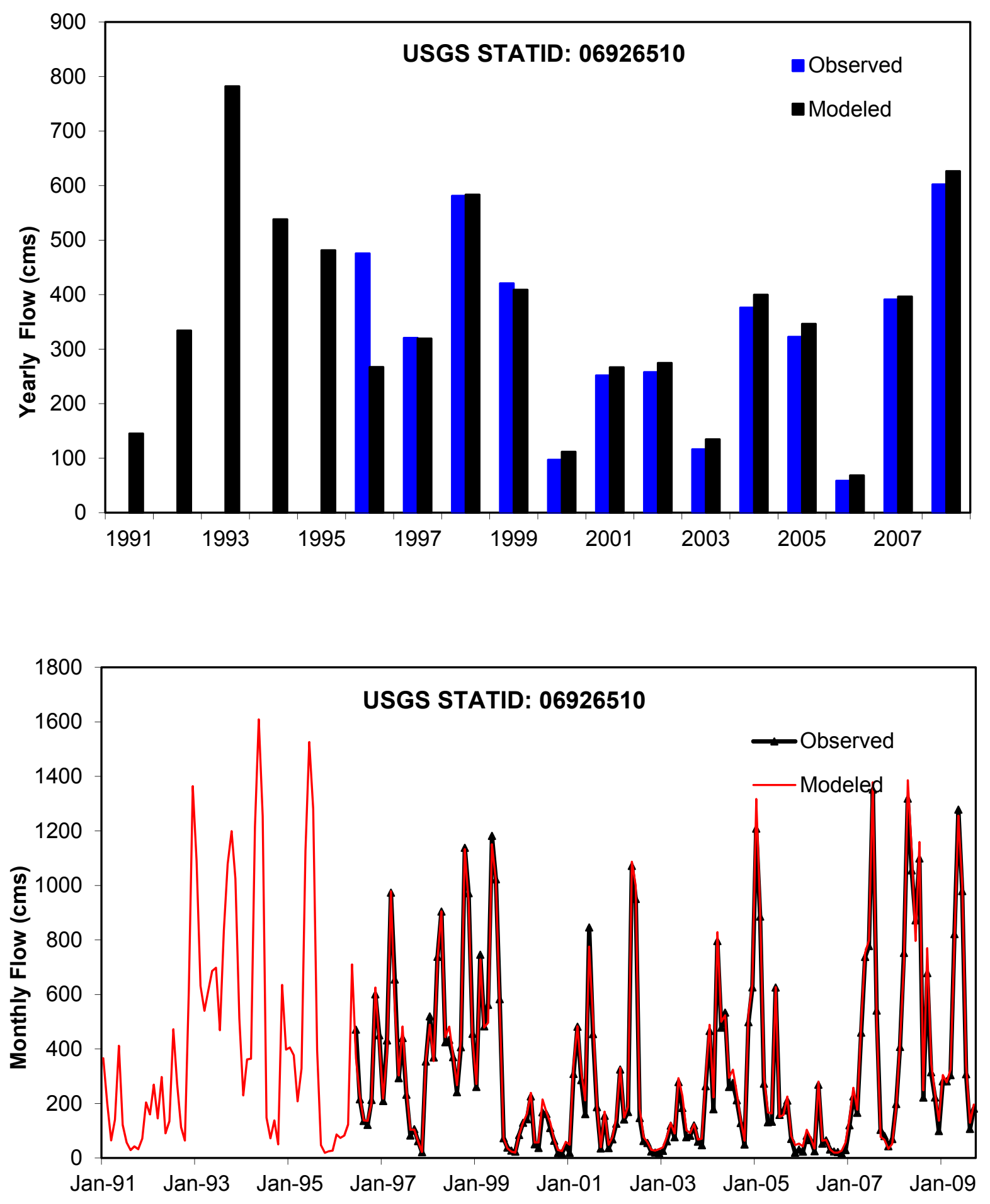

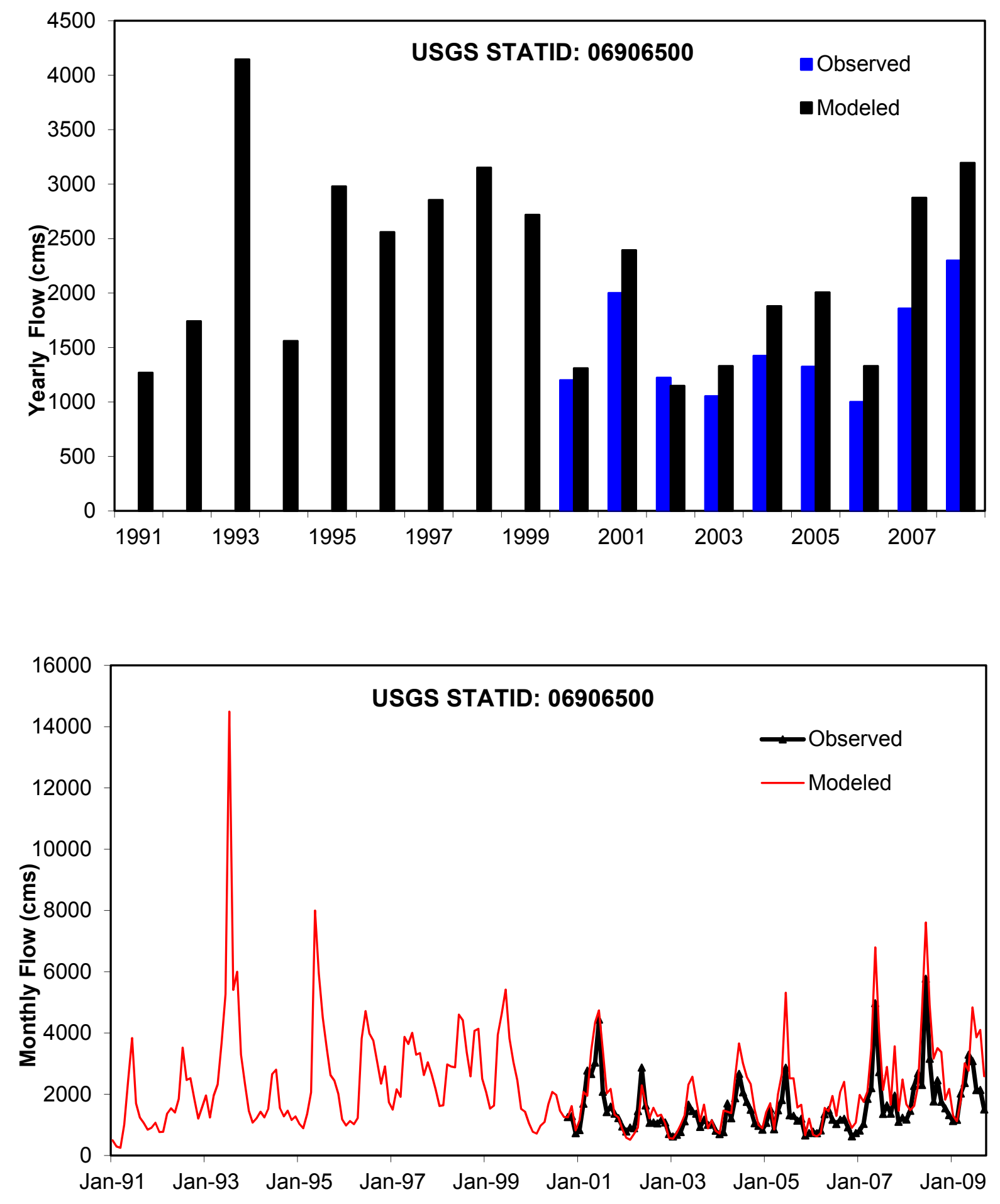

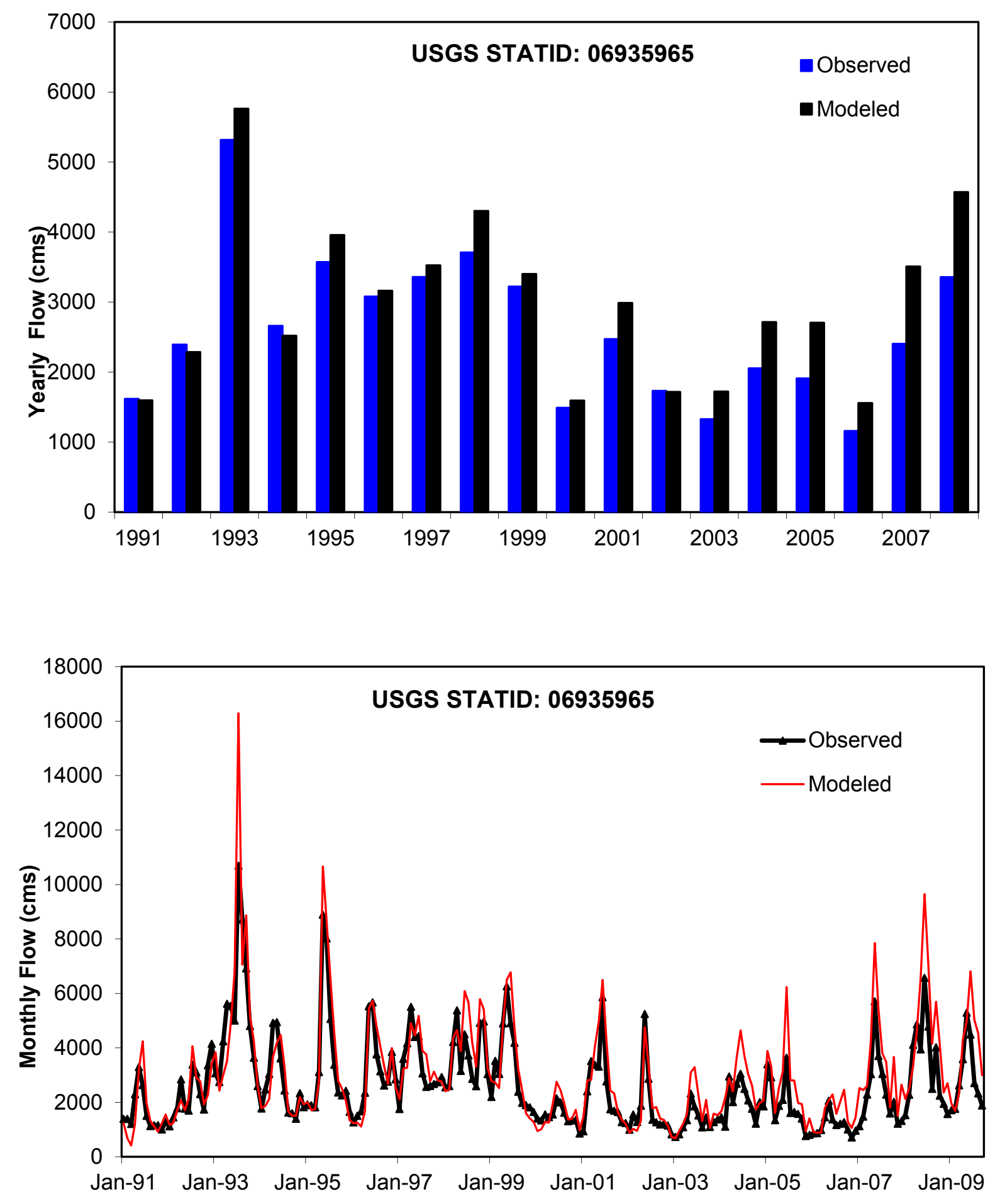
This page intentionally left blank. 


\section{APPENDIX B}

Observed and Modeled Time Series Plots of Annual (Water Year) and Monthly Total Suspended Sediment for Ten Stations in the Missouri River Basin 

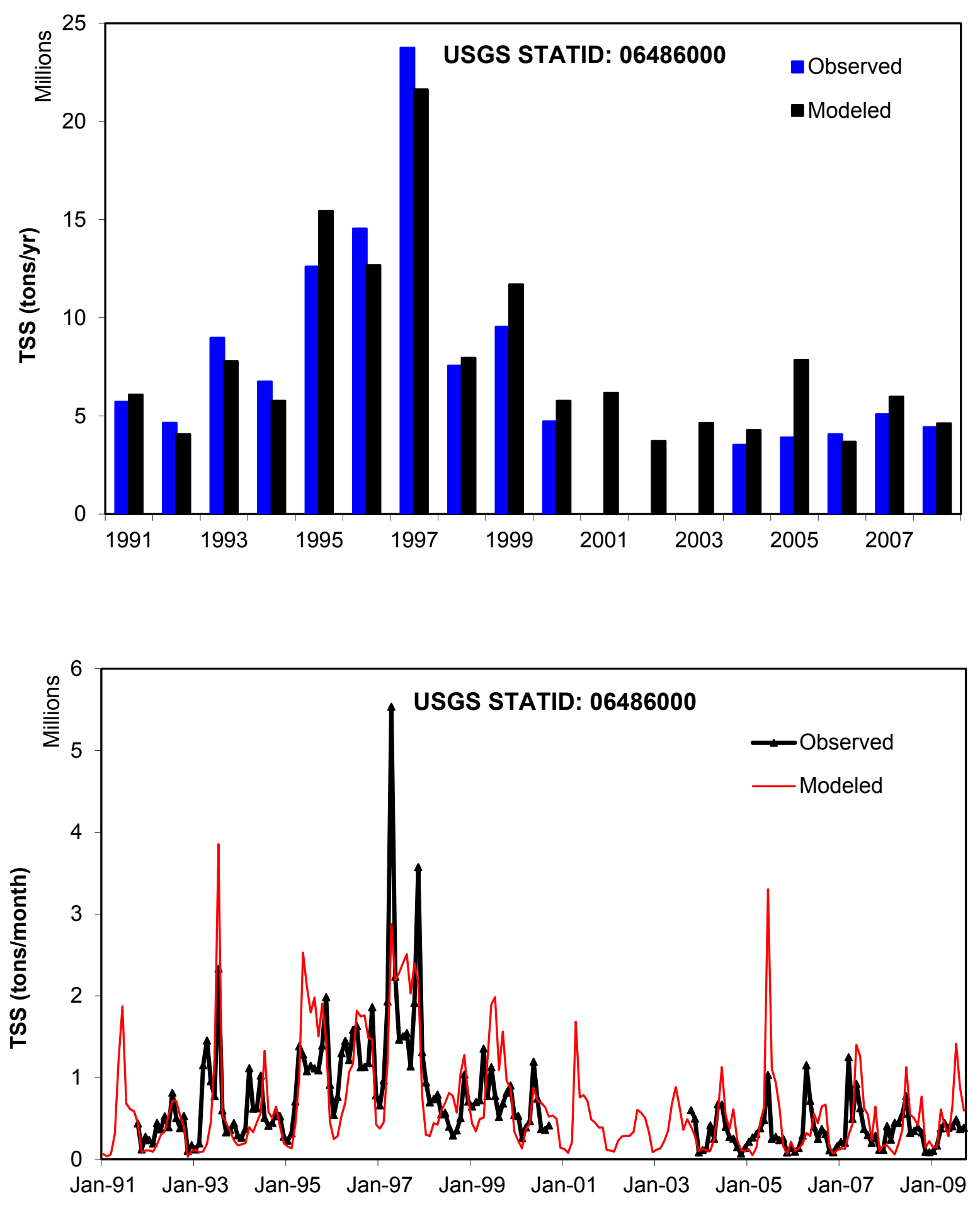


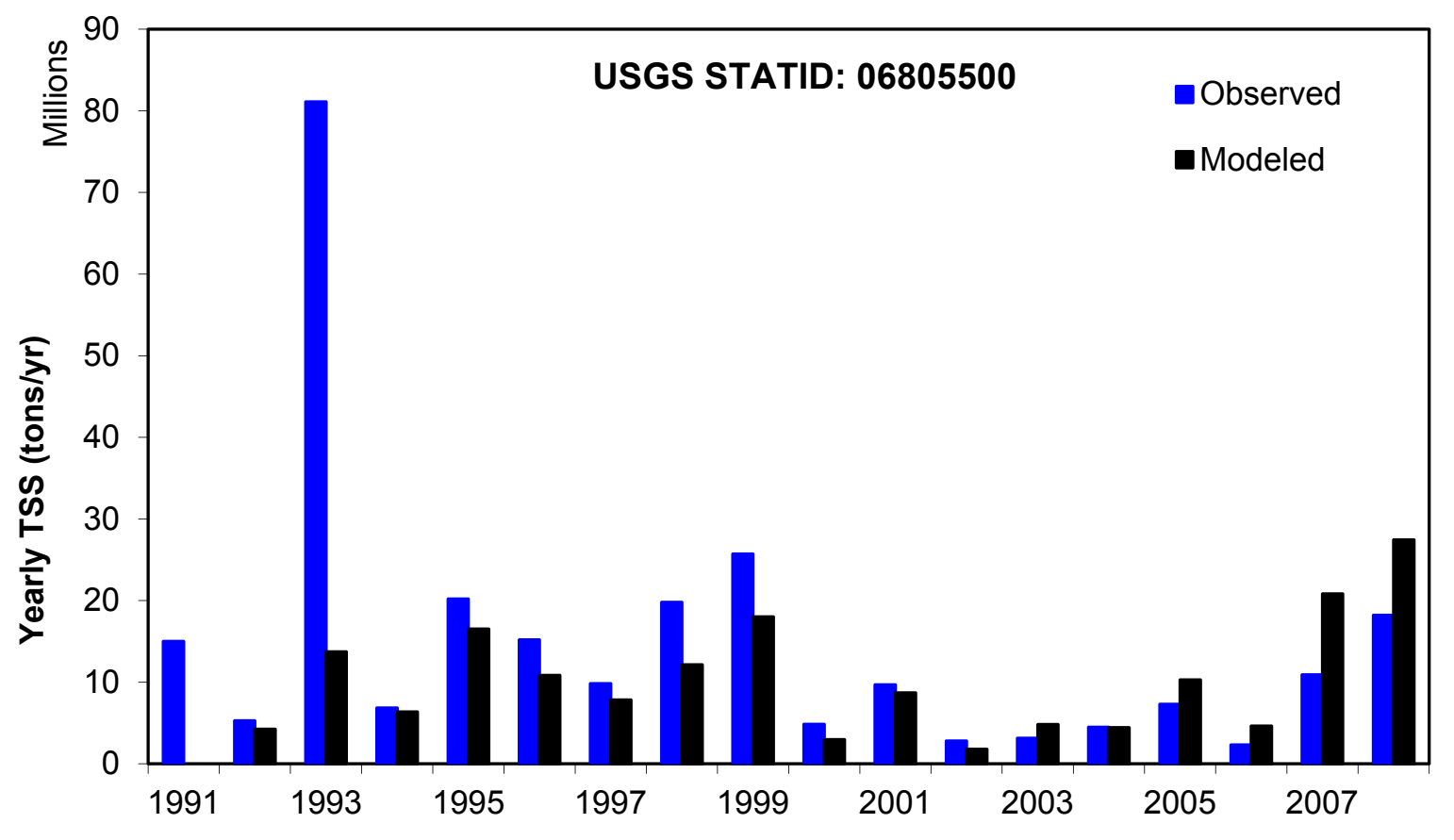



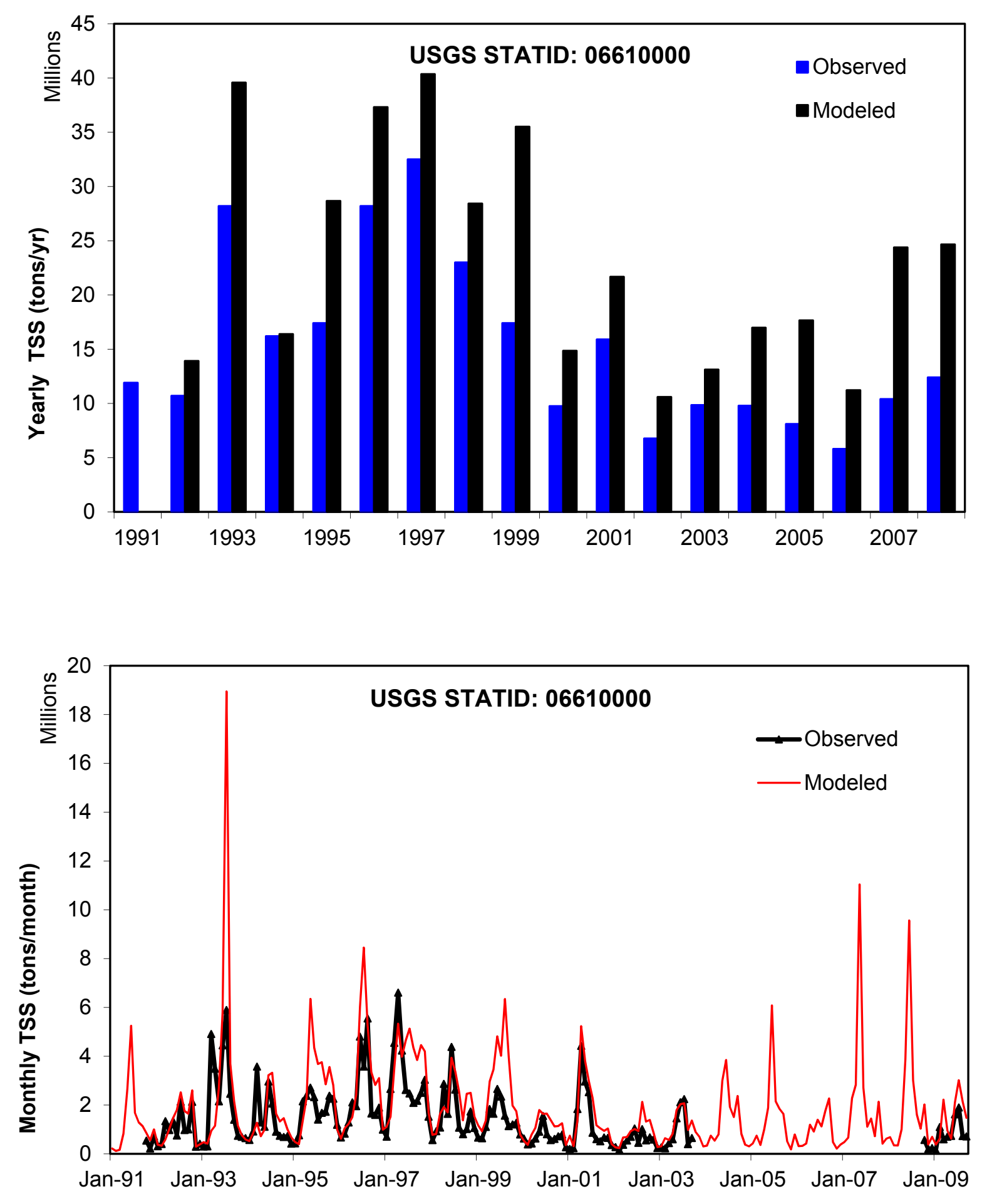

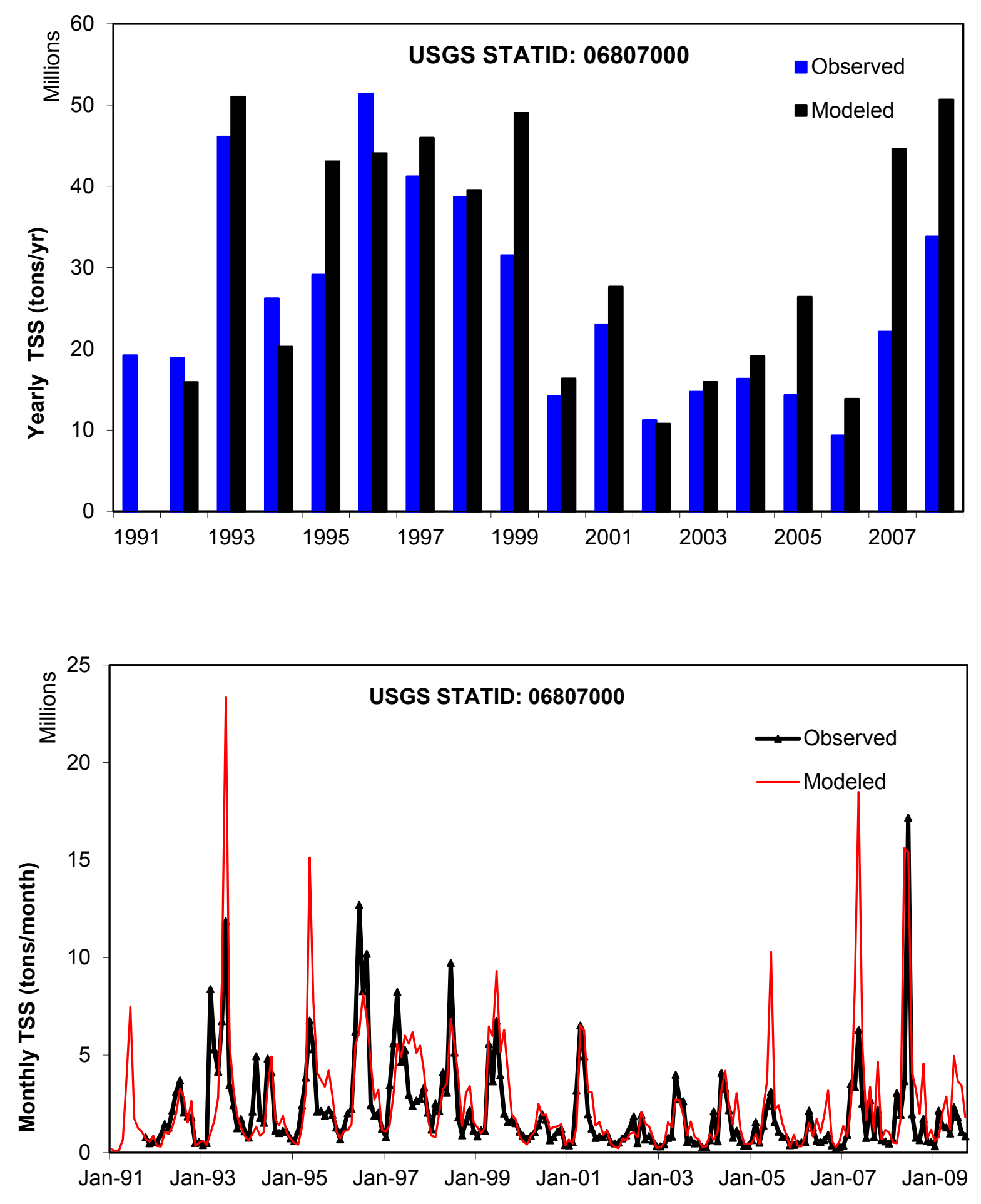


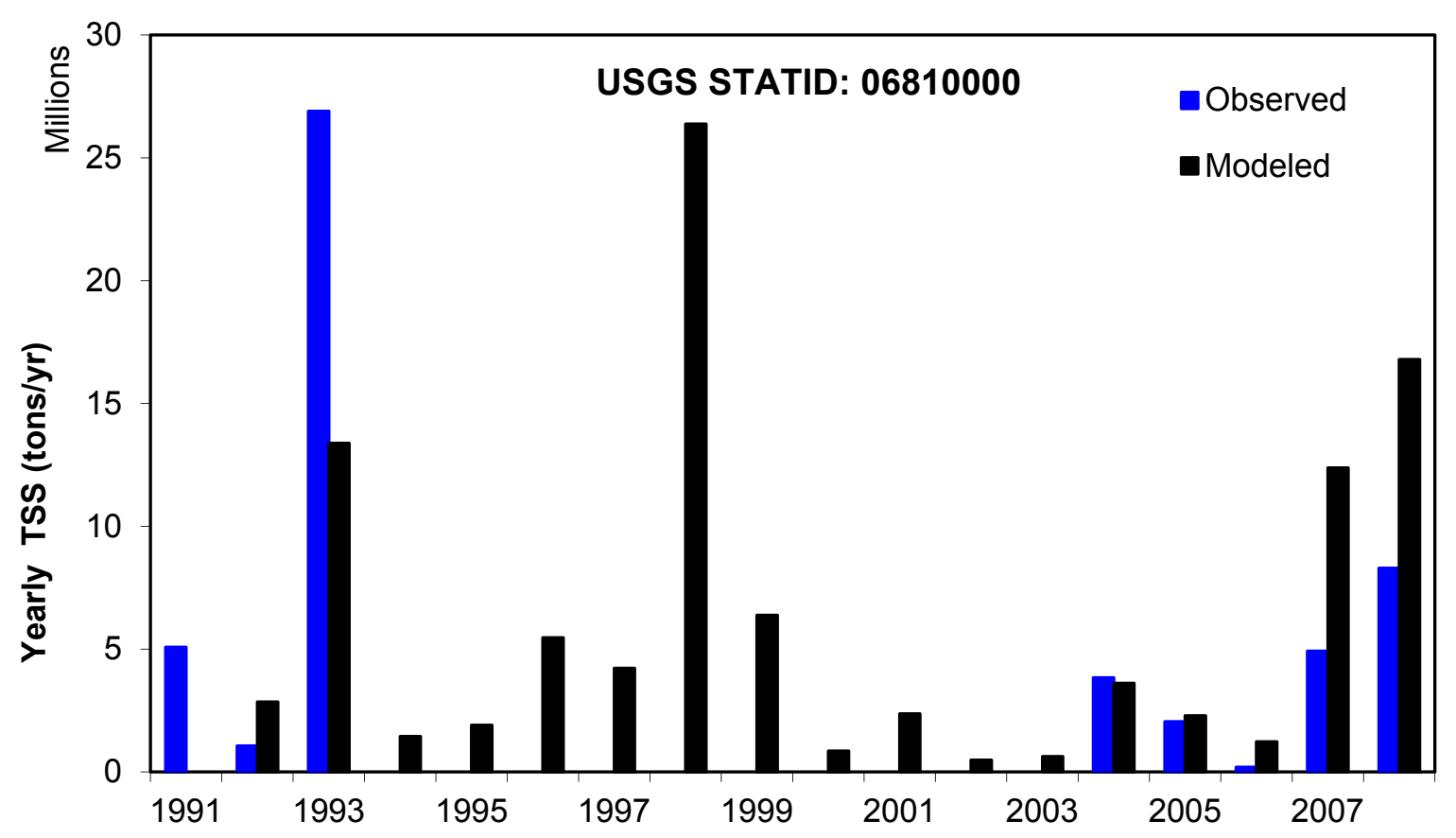



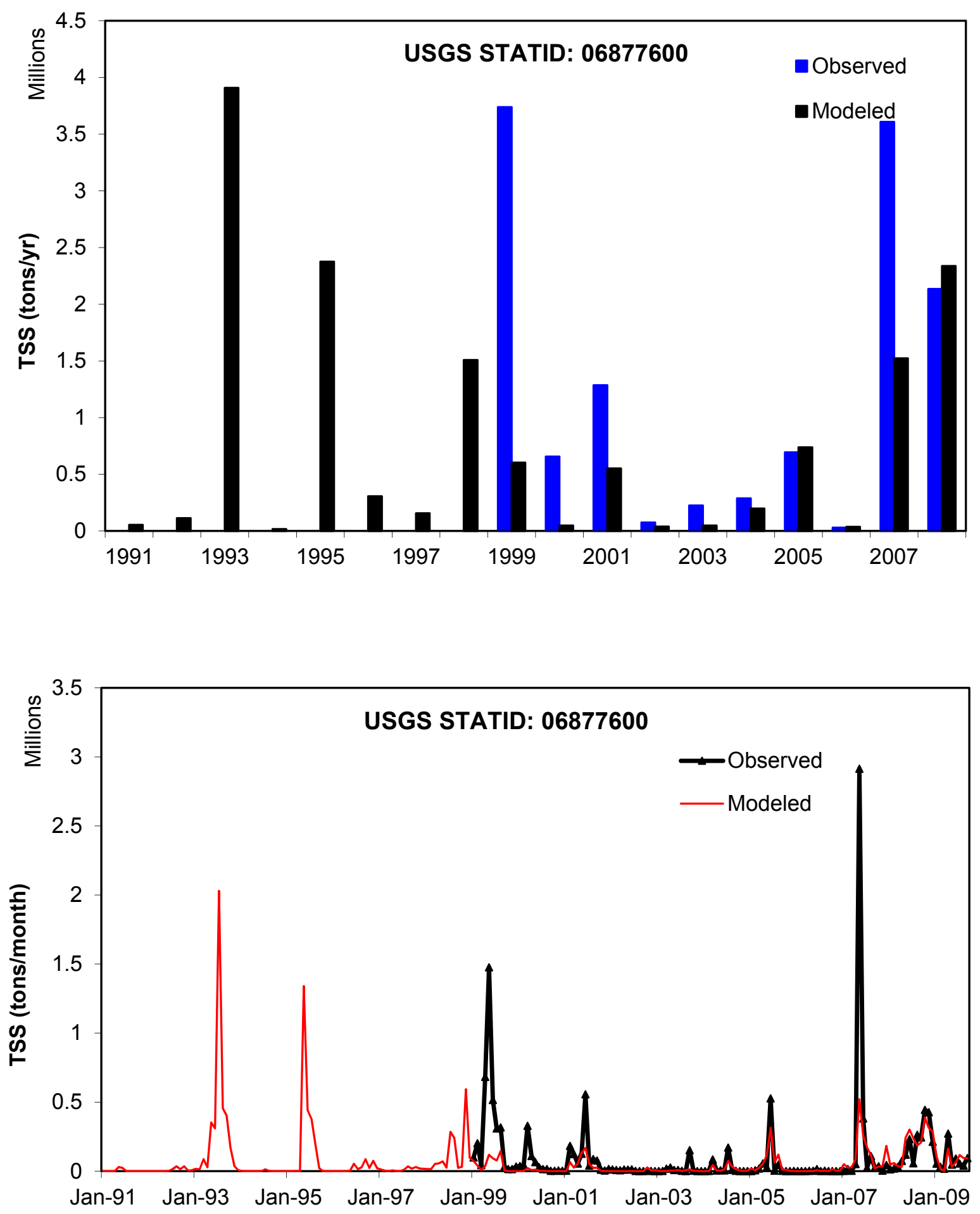

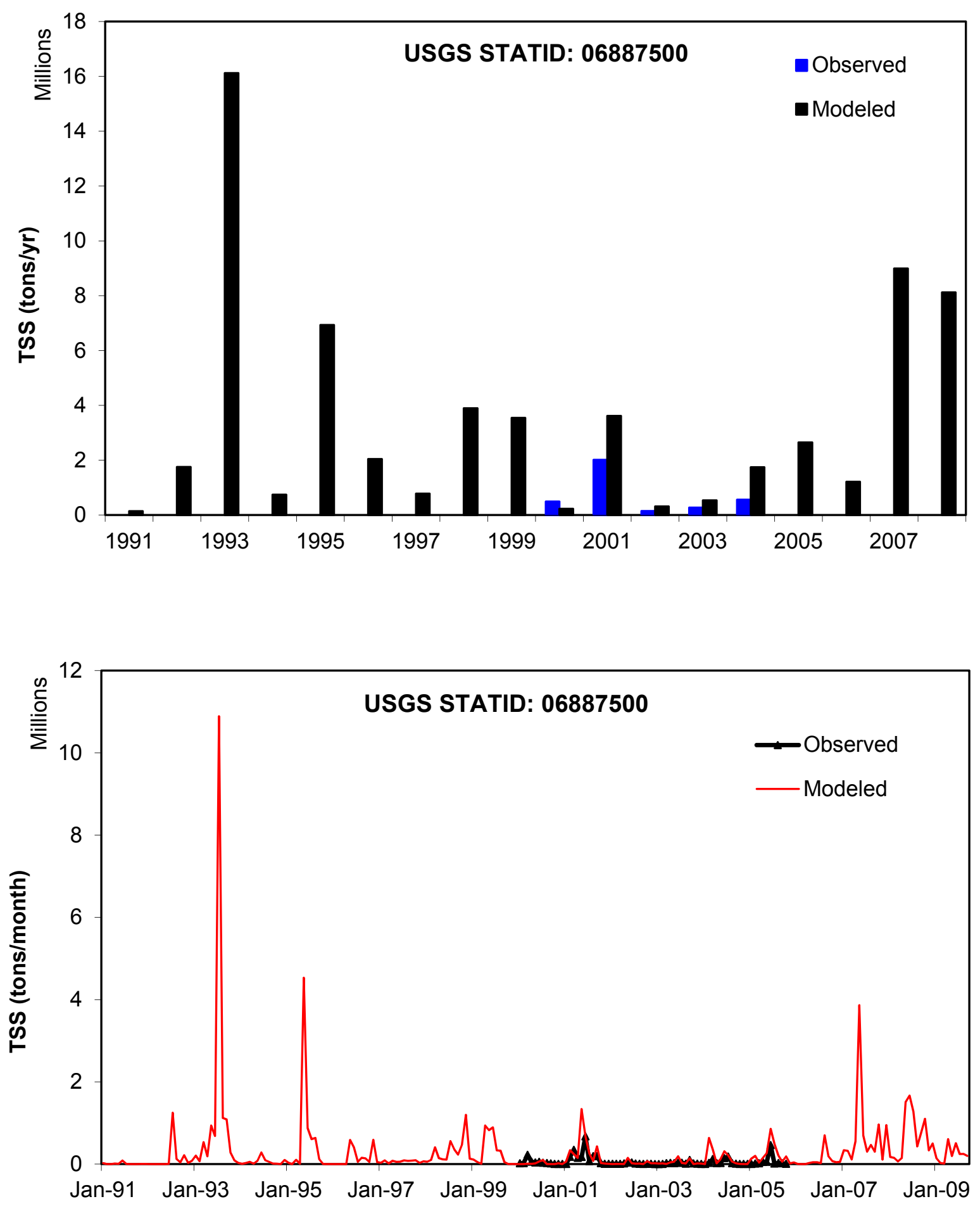

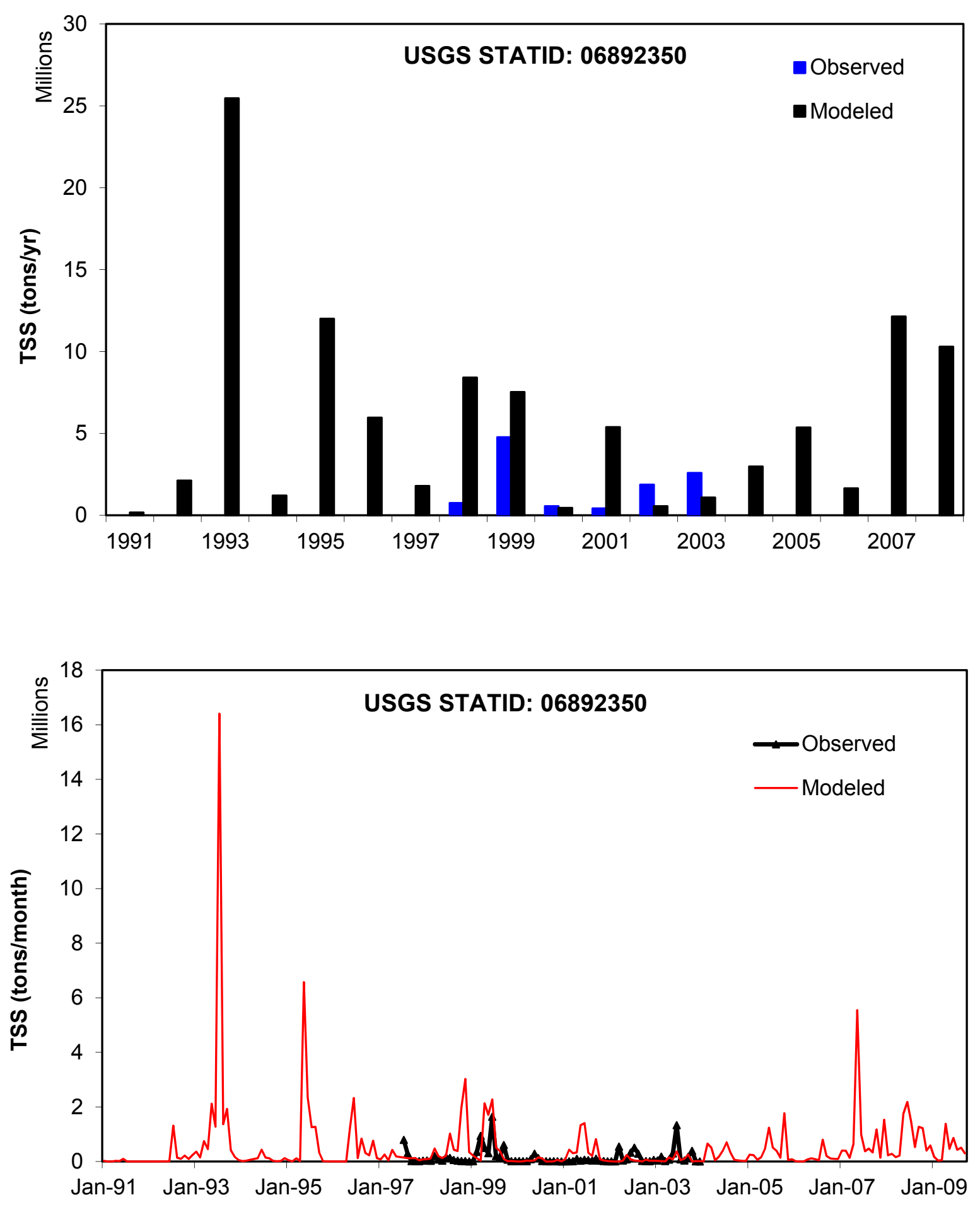


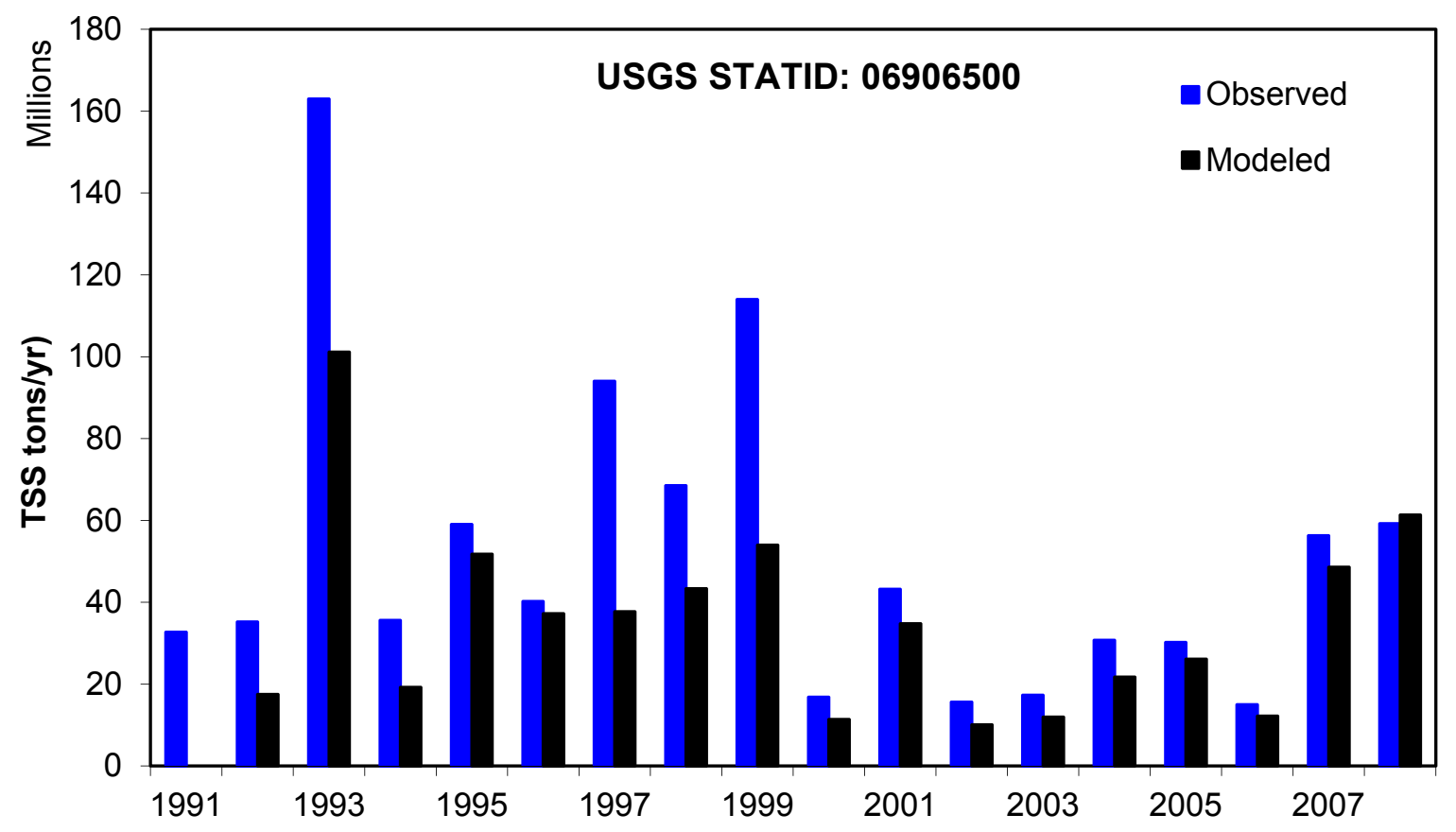



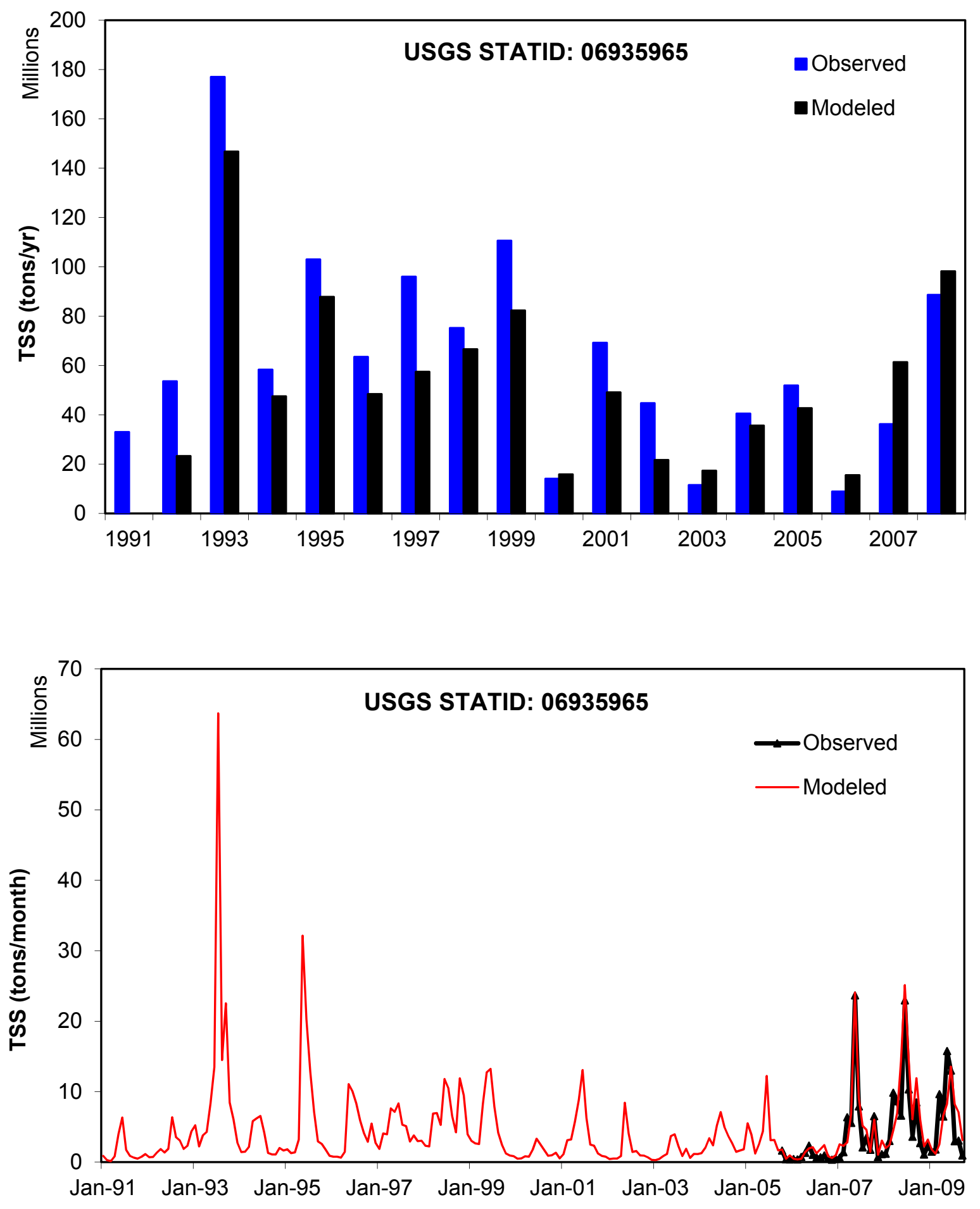
This page intentionally left blank. 


\begin{abstract}
APPENDIX C
Observed and Modeled Time Series Plots of Monthly Total Nitrogen and Phosphorous for Seven Stations in the Missouri River Basin
\end{abstract}



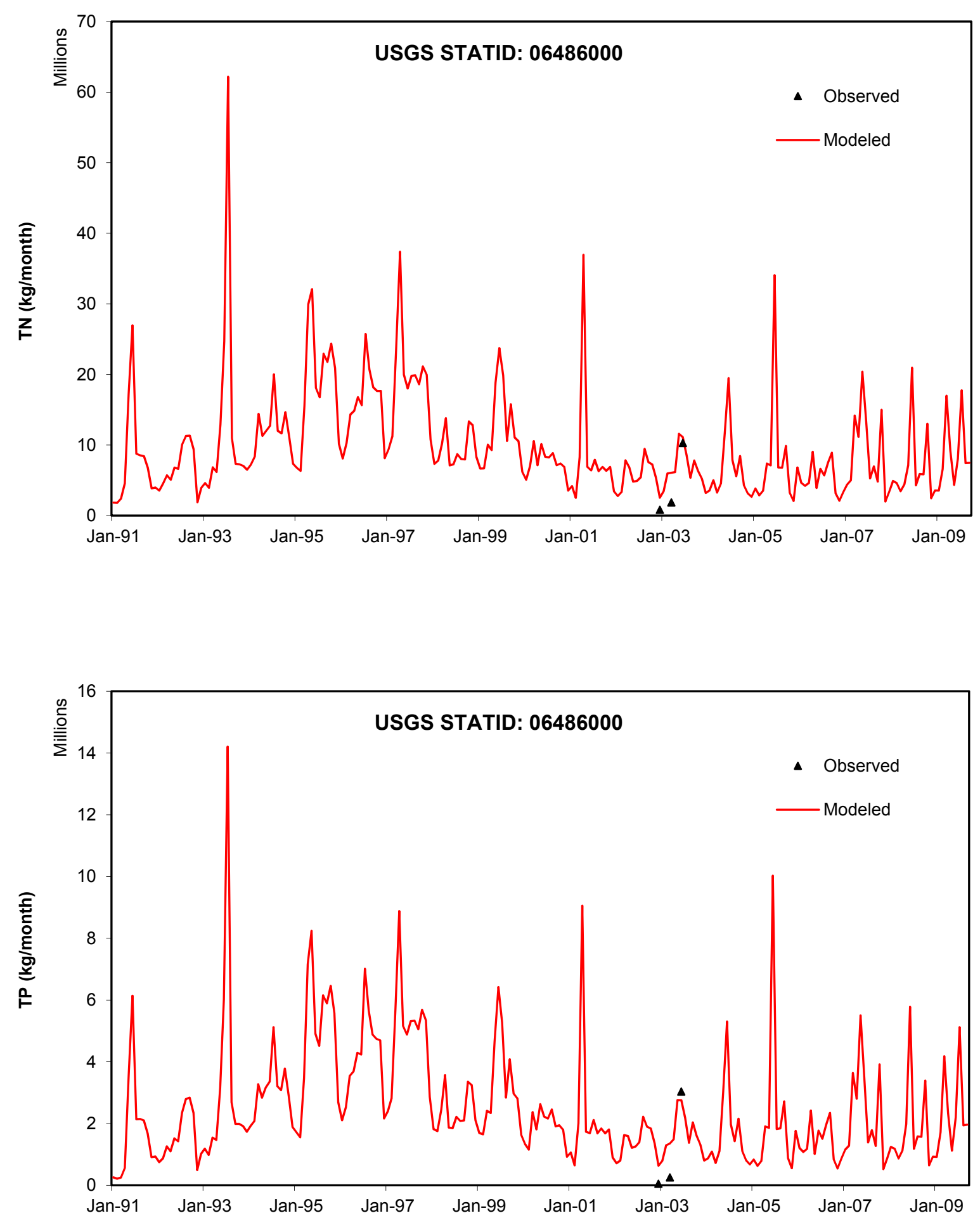

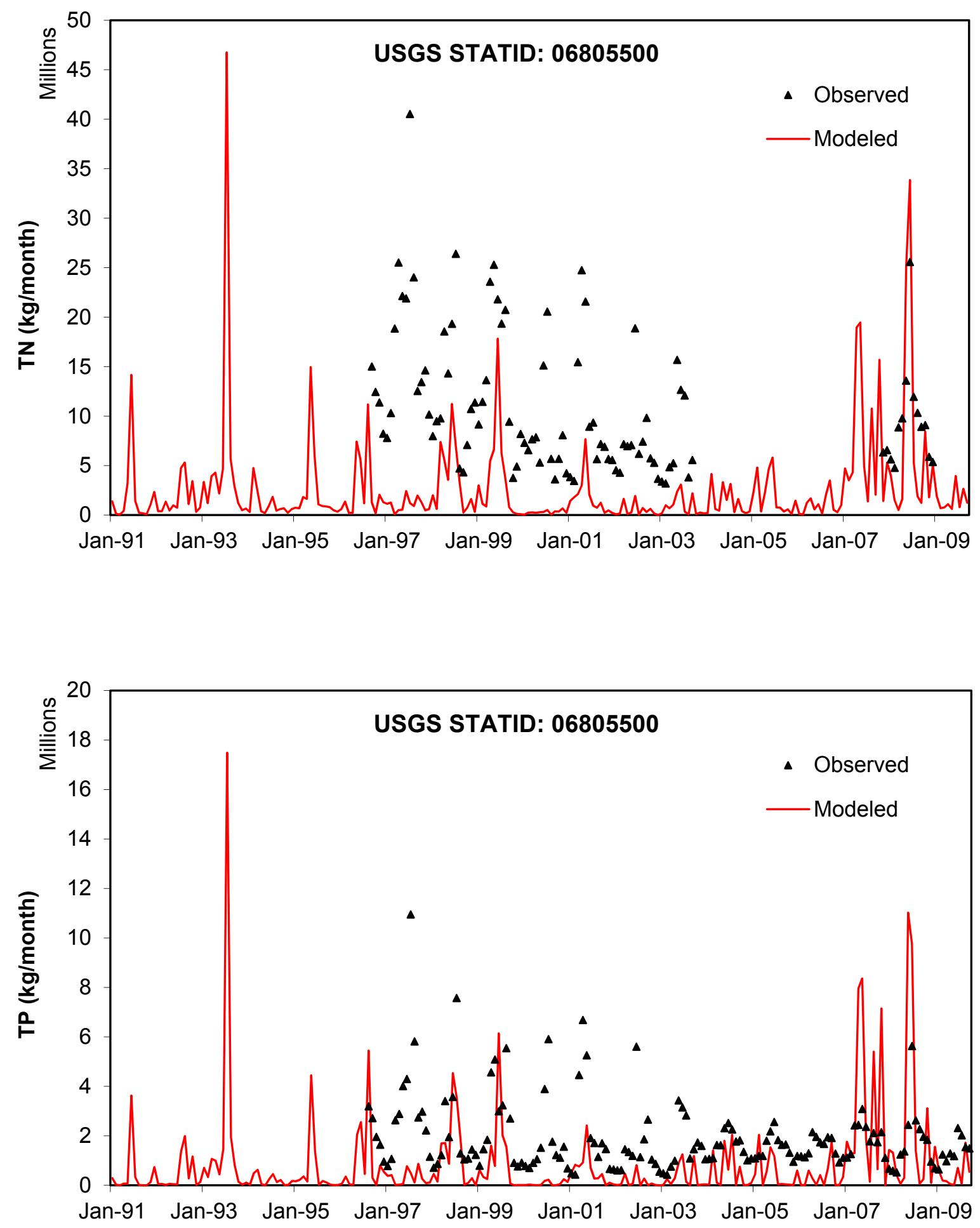

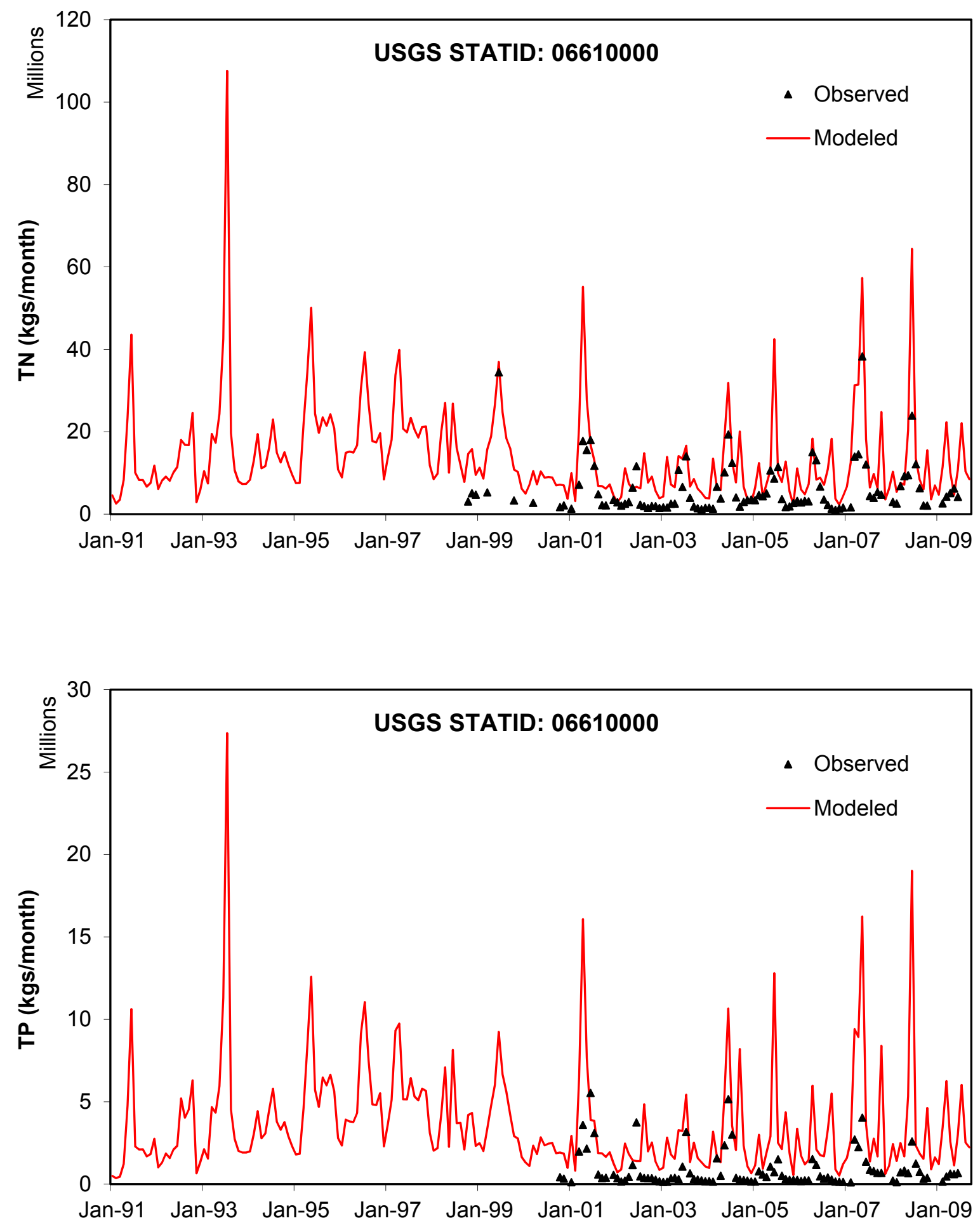

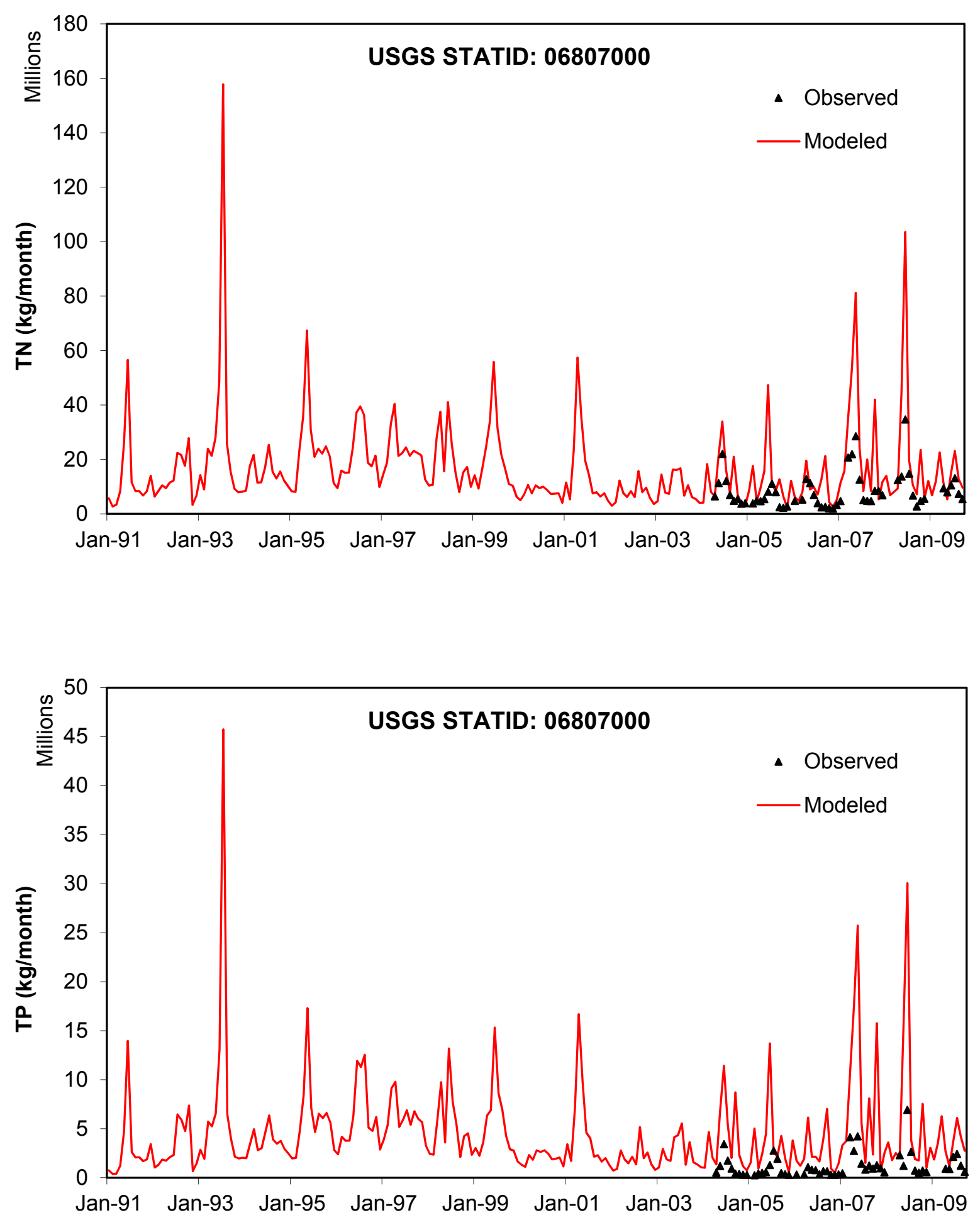

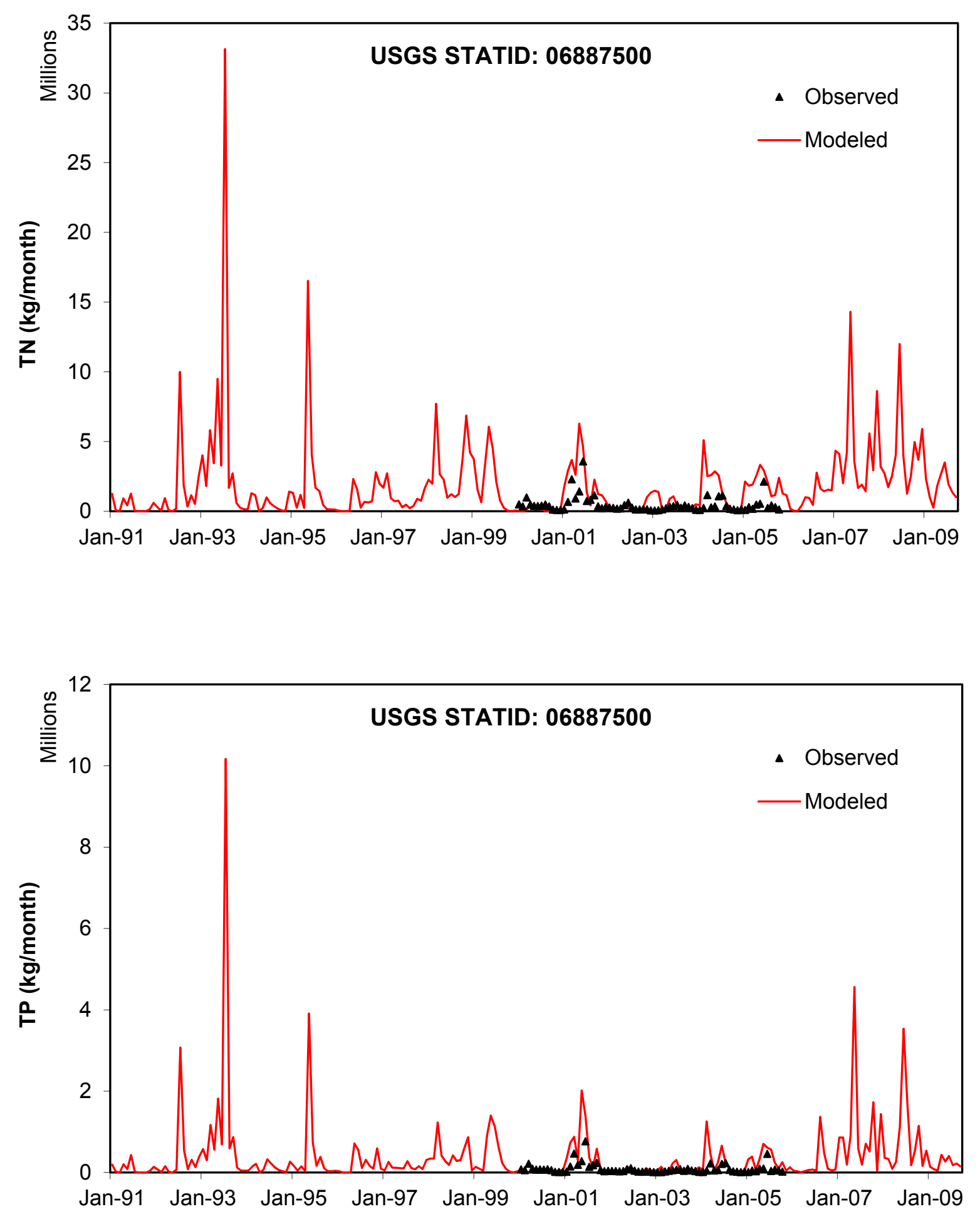

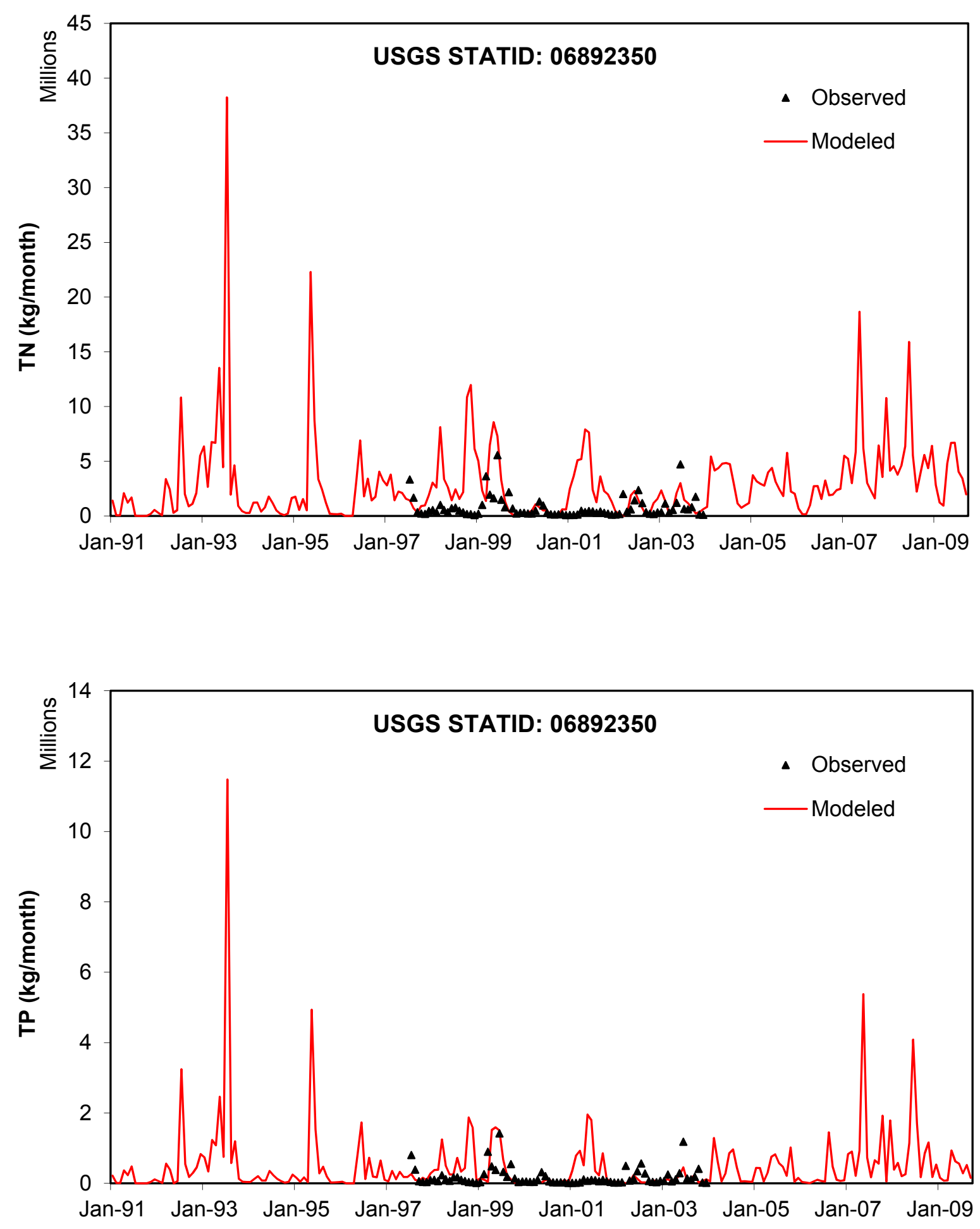

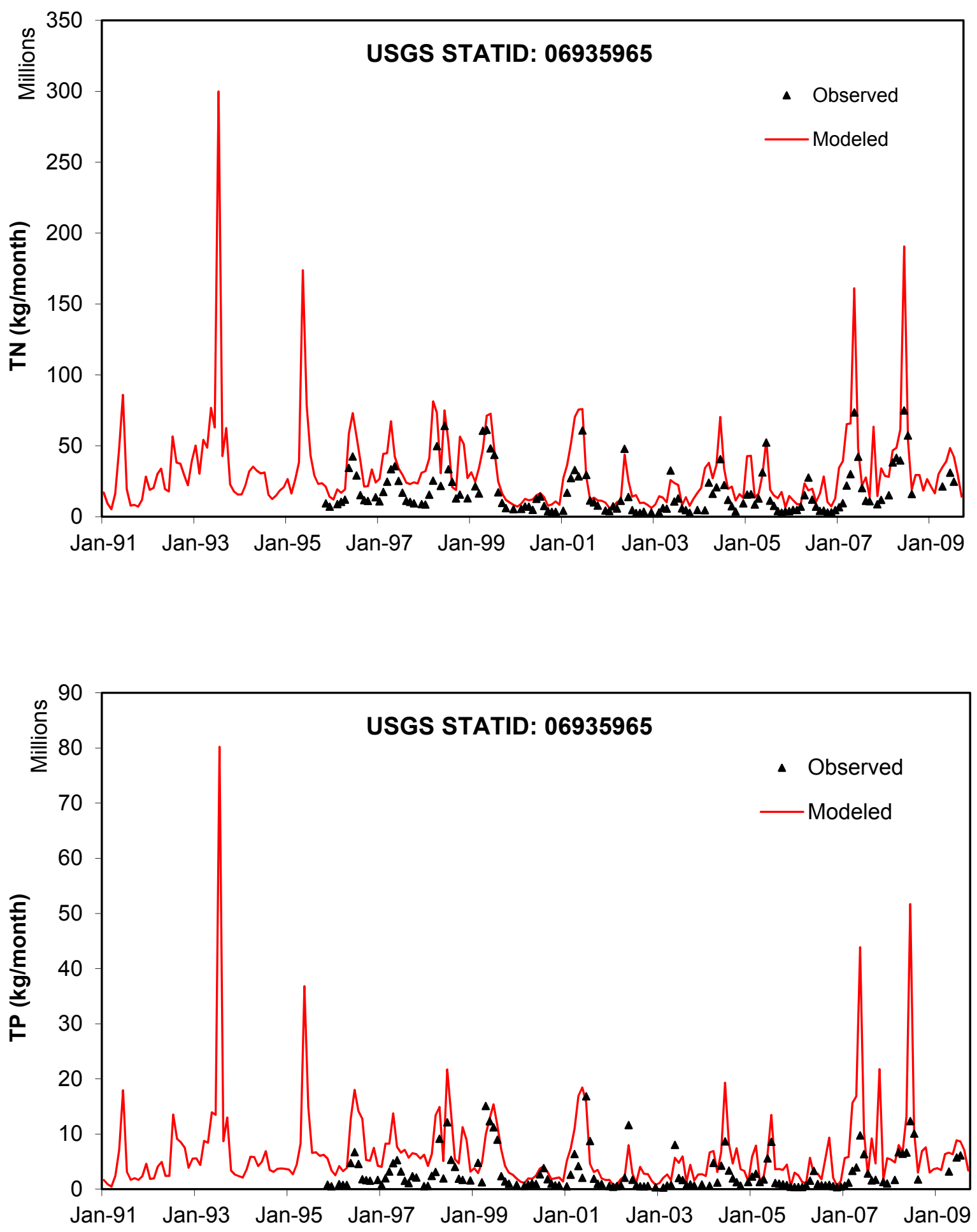


\section{APPENDIX D}

Modeled Annual Averaged (2006-2008) Results for Each Sub-basin in the Missouri River Basin 


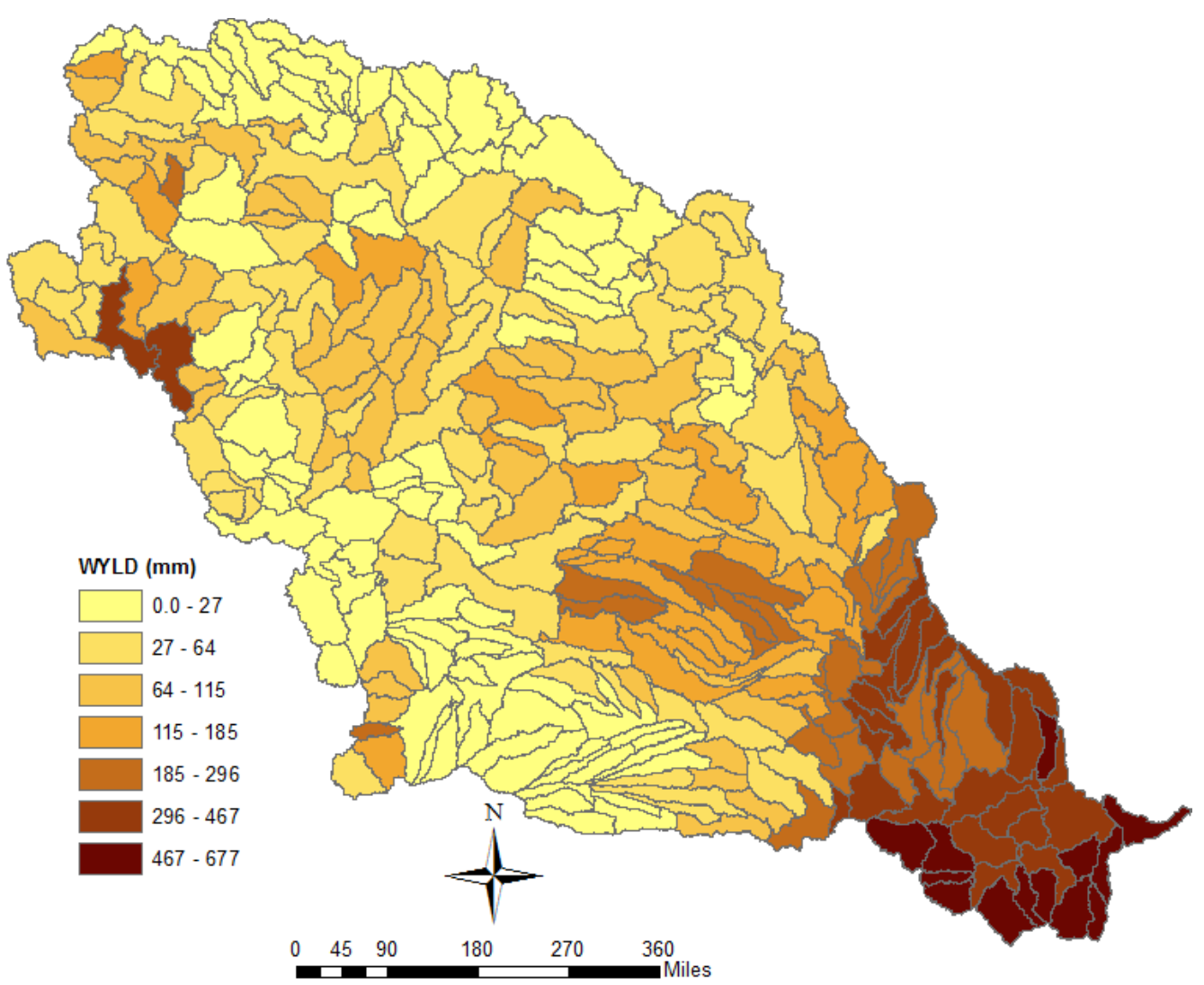

FIGURE D.1 Net amount of water that leaves the sub-basin and contributes to stream flow. 


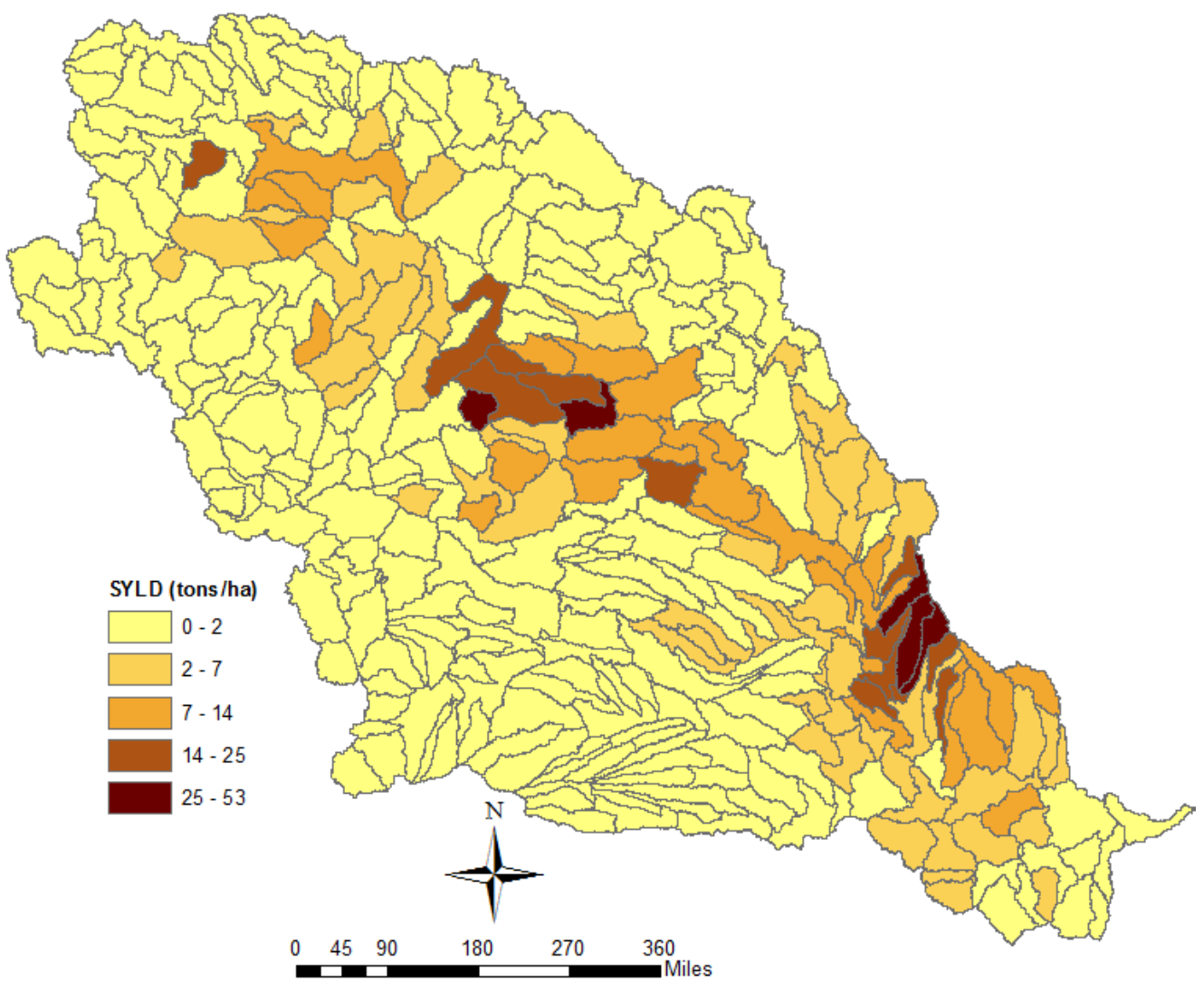

FIGURE D.2 Sediment yield transported from each sub-basin into the reach. 


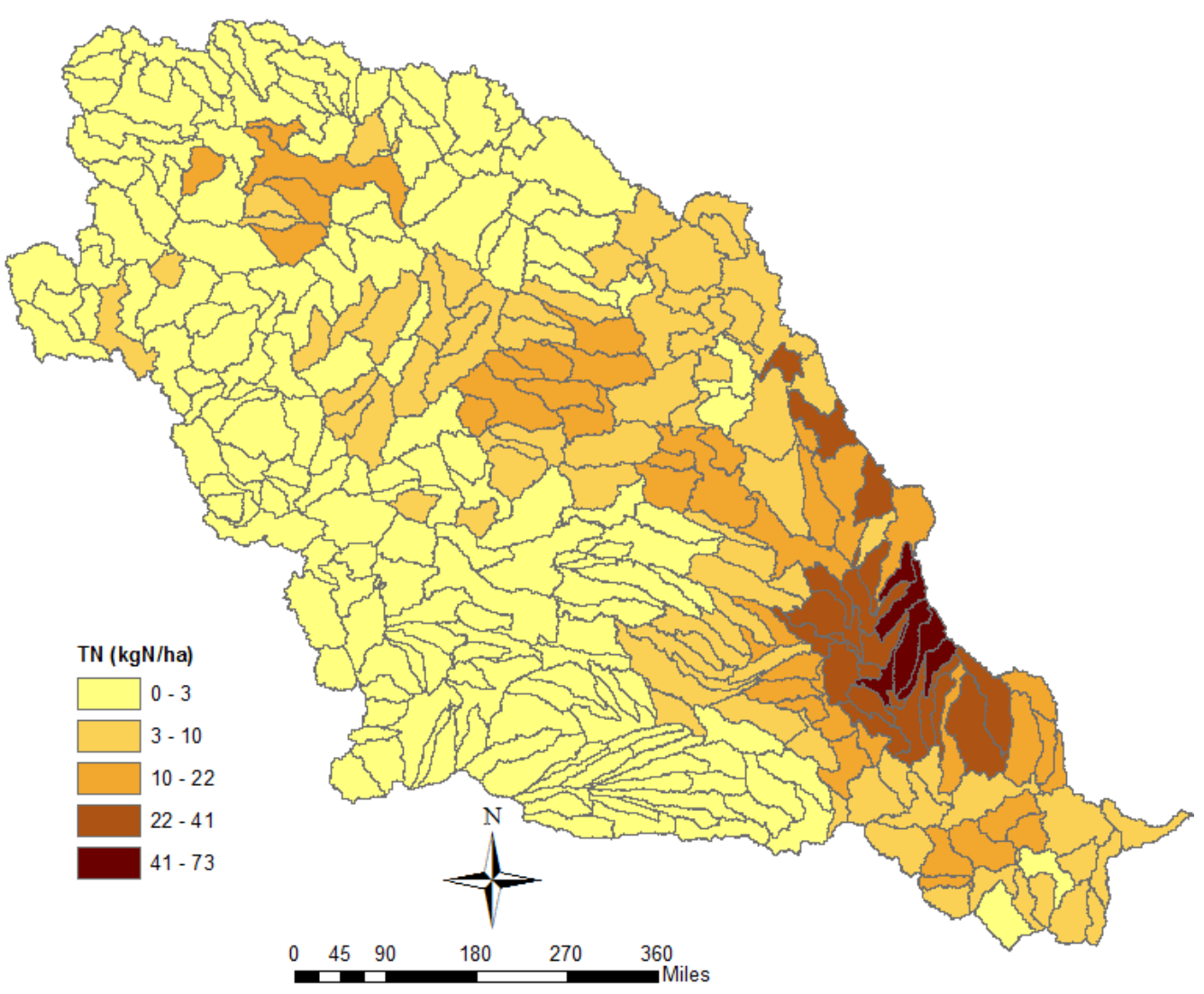

FIGURE D.3 Total Nitrogen (TN) yield transported from each sub-basin into the reach. 


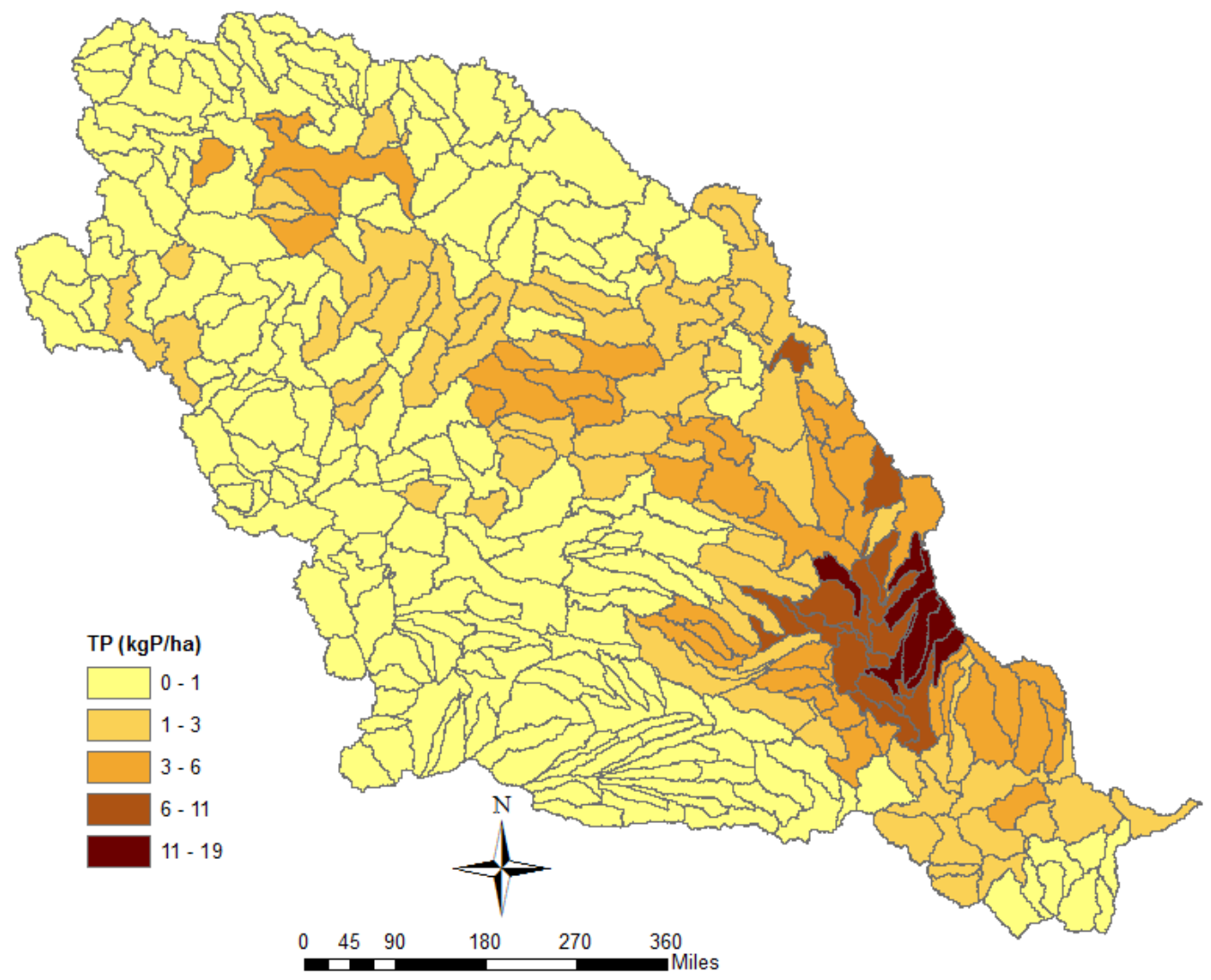

FIGURE D.4 Total Phosphorous (TP) yield transported from each sub-basin into the reach. 
This page intentionally left blank. 


\section{APPENDIX E}

\section{Water Quality Results, Land Use, and Fertilizer Application Rates at Sub-basin Scale}

TABLE E.1 Water yield, flow, total nitrogen and total phosphorus loadings.

\begin{tabular}{|c|c|c|c|c|c|c|c|}
\hline Sub-basin & Huc \# & $\begin{array}{l}\text { Land Area } \\
\text { (ha) }\end{array}$ & $\begin{array}{c}\text { WYLD } \\
\text { (water yield) } \\
\text { mm (per year) }\end{array}$ & $\begin{array}{l}\text { SYLDtha } \\
\text { (TSS metric } \\
\text { ton/ha) } \\
\end{array}$ & $\begin{array}{c}\text { Tnkgha (TN } \\
\text { kg/ha) }\end{array}$ & $\begin{array}{c}\text { Tpkgha (TP } \\
\text { kg/ha) }\end{array}$ & $\begin{array}{l}\text { Flow } \\
(\mathrm{m} 3 / \mathrm{s})\end{array}$ \\
\hline 1 & 10020001 & 599347 & 76.1460012 & 0 & 0 & 0 & 14.47168 \\
\hline 2 & 10020002 & 389087 & 39.2403336 & 0 & 0 & 0 & 4.841421 \\
\hline 3 & 10020003 & 250135 & 60.3883362 & 0 & 0 & 0 & 4.789843 \\
\hline 4 & 10020004 & 722827 & 57.2949982 & 0 & 0 & 0 & 13.1324 \\
\hline 5 & 10020005 & 336666 & 55.3363342 & 0 & 0 & 0 & 5.907489 \\
\hline 6 & 10020006 & 196564 & 46.3789978 & 0 & 0 & 0 & 2.890799 \\
\hline 7 & 10020007 & 661958 & 451.430664 & 1.245667 & 6.179667 & 1.212667 & 94.75785 \\
\hline 8 & 10020008 & 478475 & 121.65566 & 0 & 0 & 0 & 18.45801 \\
\hline 9 & 10030101 & 867717 & 36.6686656 & 0 & 0 & 0 & 10.08943 \\
\hline 10 & 10030102 & 673803 & 94.8069967 & 0 & 0 & 0 & 20.25661 \\
\hline 11 & 10030103 & 519737 & 160.534668 & 0 & 0 & 0 & 26.45734 \\
\hline 12 & 10030104 & 486262 & 98.2733358 & 0 & 0 & 0 & 15.15302 \\
\hline 13 & 10030105 & 206910 & 225.774658 & 0 & 0 & 0 & 14.81325 \\
\hline 14 & 10030201 & 333443 & 96.0963338 & 0 & 0 & 0 & 10.16065 \\
\hline 15 & 10030202 & 310921 & 160.881327 & 0 & 0 & 0 & 15.86166 \\
\hline 16 & 10030203 & 956393 & 35.6253357 & 0 & 0 & 0 & 10.8041 \\
\hline 17 & 10030204 & 257152 & 14.4246674 & 0 & 0 & 0 & 1.17622 \\
\hline 18 & 10030205 & 530775 & 29.9783325 & 0 & 0 & 0 & 5.045586 \\
\hline 19 & 10040101 & 500966 & 72.9273275 & 0 & 0 & 0 & 11.5849 \\
\hline 20 & 10040102 & 329557 & 52.8243306 & 25.04933 & 13.477 & 3.582667 & 5.520233 \\
\hline 21 & 10040103 & 716287 & 14.2053337 & 0.878333 & 1.858333 & 0.471667 & 3.226502 \\
\hline 22 & 10040104 & 1359985 & 56.4196676 & 13.02067 & 14.56433 & 4.092667 & 24.33089 \\
\hline 23 & 10040105 & 401257 & 17.3873342 & 3.527333 & 1.262 & 0.673667 & 2.212328 \\
\hline 24 & 10040106 & 316777 & 9.61866633 & 1.604 & 0.859333 & 0.464 & 0.966187 \\
\hline 25 & 10040201 & 1040047 & 26.6859996 & 3.844333 & 3.399334 & 0.983667 & 8.800955 \\
\hline 26 & 10040202 & 498428 & 64.4463298 & 13.80033 & 11.03 & 3.358 & 10.18577 \\
\hline 27 & 10040203 & 176073 & 90.6849976 & 6.814667 & 8.134667 & 2.242 & 5.063149 \\
\hline 28 & 10040204 & 303678 & 110.12266 & 8.052667 & 9.075 & 2.737 & 10.60432 \\
\hline 29 & 10040205 & 437608 & 68.364329 & 13.22433 & 12.99833 & 3.903667 & 9.486548 \\
\hline 30 & 10050001 & 249933 & 19.9593341 & 2.373333 & 3.394333 & 0.862 & 1.581843 \\
\hline 31 & 10050002 & 585085 & 10.4860001 & 0.514667 & 1.092667 & 0.266333 & 1.945459 \\
\hline 32 & 10050003 & 121266 & 9.2253329 & 0.377 & 1.237 & 0.291667 & 0.354744 \\
\hline 33 & 10050004 & 909646 & 10.1489995 & 0.290667 & 0.788 & 0.193333 & 2.927447 \\
\hline 34 & 10050005 & 209094 & 6.81966654 & 0.518667 & 1.241333 & 0.316667 & 0.452167 \\
\hline 35 & 10050006 & 256380 & 4.54833349 & 0.338667 & 0.935667 & 0.226333 & 0.369768 \\
\hline
\end{tabular}


TABLE E.1 (Cont.)

\begin{tabular}{|c|c|c|c|c|c|c|c|}
\hline Sub-basin & Huc \# & $\begin{array}{l}\text { Land Area } \\
\text { (ha) }\end{array}$ & $\begin{array}{c}\text { WYLD } \\
\text { (water yield) } \\
\text { mm (per year) }\end{array}$ & $\begin{array}{l}\text { SYLDtha } \\
\text { (TSS metric } \\
\text { ton/ha) } \\
\end{array}$ & $\begin{array}{c}\text { Tnkgha (TN } \\
\text { kg/ha) }\end{array}$ & $\begin{array}{c}\text { Tpkgha (TP } \\
\text { kg/ha) }\end{array}$ & $\begin{array}{l}\text { Flow } \\
(\mathrm{m} 3 / \mathrm{s}) \\
\end{array}$ \\
\hline 36 & 10050007 & 282575 & 7.09200033 & 0.293667 & 0.986 & 0.226667 & 0.635471 \\
\hline 37 & 10050008 & 445068 & 6.05599976 & 0.064 & 0.284333 & 0.057 & 0.854685 \\
\hline 38 & 10050009 & 183993 & 74.7423299 & 7.717 & 16.33167 & 4.018 & 4.360761 \\
\hline 39 & 10050010 & 244902 & 7.81866709 & 1.284667 & 1.637667 & 0.443333 & 0.607183 \\
\hline 40 & 10050011 & 468178 & 3.8326664 & 0.161333 & 0.452333 & 0.114333 & 0.568991 \\
\hline 41 & 10050012 & 394992 & 43.7873332 & 4.201 & 8.158 & 2.326667 & 5.484412 \\
\hline 42 & 10050013 & 619599 & 3.9240001 & 0.000333 & 0.039 & 0.001 & 0.770962 \\
\hline 43 & 10050014 & 473759 & 13.7290014 & 1.298667 & 2.837667 & 0.790333 & 2.06248 \\
\hline 44 & 10050015 & 354394 & 10.9566663 & 0.904667 & 1.823 & 0.491667 & 1.231283 \\
\hline 45 & 10050016 & 187986 & 6.643333344 & 0.859667 & 1.240333 & 0.329333 & 0.396008 \\
\hline 46 & 10060001 & 519223 & 17.8803329 & 1.184667 & 3.155333 & 0.790667 & 2.943898 \\
\hline 47 & 10060002 & 547784 & 11.6079992 & 5.814667 & 3.655667 & 0.954333 & 2.016324 \\
\hline 48 & 10060003 & 600858 & 7.604333324 & 0.522333 & 1.507333 & 0.353333 & 1.44886 \\
\hline 49 & 10060004 & 265448 & 3.73533312 & 0.322333 & 0.824333 & 0.198667 & 0.314414 \\
\hline 50 & 10060005 & 325679 & 27.0570017 & 0.863333 & 2.074667 & 0.528333 & 2.794234 \\
\hline 51 & 10060006 & 889917 & 5.17566649 & 0.153667 & 0.626 & 0.157333 & 1.460526 \\
\hline 52 & 10060007 & 264153 & 12.8923327 & 0.711667 & 2.188667 & 0.576 & 1.079892 \\
\hline 53 & 10070001 & 671484 & 453.35734 & 0.169 & 2.725333 & 1.505667 & 96.5317 \\
\hline 54 & 10070002 & 767713 & 73.4079997 & 0.367 & 1.338667 & 0.304 & 17.87046 \\
\hline 55 & 10070003 & 221267 & 86.5503337 & 4.496667 & 8.364333 & 1.832 & 6.072651 \\
\hline 56 & 10070004 & 406943 & 53.6633301 & 0.633667 & 2.102333 & 0.482333 & 6.924755 \\
\hline 57 & 10070005 & 276230 & 101.237325 & 1.477333 & 2.800333 & 0.603667 & 8.867564 \\
\hline 58 & 10070006 & 723309 & 14.4060008 & 0.114 & 0.236 & 0.067 & 3.304159 \\
\hline 59 & 10070007 & 520156 & 30.9609985 & 0.361333 & 0.931 & 0.224 & 5.106724 \\
\hline 60 & 10070008 & 155970 & 63.2666677 & 0.641 & 1.324667 & 0.369 & 3.12902 \\
\hline 61 & 10080001 & 660240 & 44.1126658 & 0.002667 & 0.006 & 0.001 & 9.235465 \\
\hline 62 & 10080002 & 288891 & 36.9090017 & 1.367 & 2.253333 & 0.612333 & 3.381114 \\
\hline 63 & 10080003 & 208079 & 49.7309977 & 0.663 & 1.190333 & 0.349667 & 3.281321 \\
\hline 64 & 10080004 & 190468 & 6.65399996 & 0.172667 & 0.264667 & 0.072 & 0.401883 \\
\hline 65 & 10080005 & 441815 & 19.9020004 & 0.068 & 0.042333 & 0.024 & 2.788243 \\
\hline 66 & 10080006 & 221727 & 19.9980011 & 0.155 & 0.178667 & 0.066 & 1.406041 \\
\hline 67 & 10080007 & 899443 & 10.8956655 & 0.604667 & 0.816667 & 0.248333 & 3.107571 \\
\hline 68 & 10080008 & 521273 & 28.8203328 & 1.148667 & 2.928 & 0.650667 & 4.763843 \\
\hline 69 & 10080009 & 297761 & 50.0916646 & 1.216333 & 1.118 & 0.38 & 4.729623 \\
\hline 70 & 10080010 & 466664 & 37.2179972 & 0.026 & 0.070667 & 0.017333 & 5.507446 \\
\hline 71 & 10080011 & 112894 & 7.57199987 & 0.178333 & 0.173 & 0.070333 & 0.271066 \\
\hline 72 & 10080012 & 221137 & 68.717336 & 0.005 & 0.050333 & 0.014 & 4.818602 \\
\hline 73 & 10080013 & 168513 & 91.7593282 & 0.046667 & 0.176667 & 0.055 & 4.903165 \\
\hline 74 & 10080014 & 384554 & 1.53000005 & 0.002 & 0.003667 & 0.001 & 0.18657 \\
\hline
\end{tabular}


TABLE E.1 (Cont.)

\begin{tabular}{|c|c|c|c|c|c|c|c|}
\hline Sub-basin & Huc \# & $\begin{array}{l}\text { Land Area } \\
\text { (ha) }\end{array}$ & $\begin{array}{c}\text { WYLD } \\
\text { (water yield) } \\
\text { mm (per year) }\end{array}$ & $\begin{array}{c}\text { SYLDtha } \\
\text { (TSS metric } \\
\text { ton/ha) } \\
\end{array}$ & $\begin{array}{c}\text { Tnkgha (TN } \\
\text { kg/ha) }\end{array}$ & $\begin{array}{c}\text { Tpkgha (TP } \\
\text { kg/ha) }\end{array}$ & $\begin{array}{l}\text { Flow } \\
(\mathrm{m} 3 / \mathrm{s}) \\
\end{array}$ \\
\hline 75 & 10080015 & 508020 & 54.2516683 & 2.278667 & 1.639333 & 0.796667 & 8.73951 \\
\hline 76 & 10080016 & 336096 & 110.949331 & 12.89333 & 7.94 & 2.751667 & 11.82447 \\
\hline 77 & 10090101 & 656269 & 73.7663269 & 4.425333 & 3.581334 & 1.135333 & 15.35088 \\
\hline 78 & 10090102 & 744083 & 106.048004 & 6.628333 & 7.404 & 2.126667 & 25.02174 \\
\hline 79 & 10090201 & 254186 & 71.1446635 & 0.538333 & 0.780333 & 0.231333 & 5.734391 \\
\hline 80 & 10090202 & 649502 & 80.8153381 & 1.416333 & 3.816 & 0.991333 & 16.64437 \\
\hline 81 & 10090203 & 315121 & 29.2660014 & 0.199667 & 0.396 & 0.116 & 2.924383 \\
\hline 82 & 10090204 & 208925 & 72.4156698 & 1.169333 & 2.361667 & 0.661667 & 4.79752 \\
\hline 83 & 10090205 & 247386 & 53.2590027 & 2.585667 & 4.885334 & 1.331 & 4.177929 \\
\hline 84 & 10090206 & 298899 & 83.3050028 & 5.314667 & 8.079667 & 2.215667 & 7.895675 \\
\hline 85 & 10090207 & 275725 & 67.0146688 & 1.894 & 2.922666 & 0.865333 & 5.859222 \\
\hline 86 & 10090208 & 524939 & 107.935669 & 6.103333 & 8.780333 & 2.696333 & 17.96666 \\
\hline 87 & 10090209 & 486287 & 66.9423319 & 3.217667 & 4.434667 & 1.475667 & 10.32254 \\
\hline 88 & 10090210 & 208140 & 78.741333 & 3.087333 & 3.549667 & 1.258 & 5.196993 \\
\hline 89 & 10100001 & 1244475 & 136.026326 & 3.397 & 3.738 & 1.27 & 53.67875 \\
\hline 90 & 10100002 & 226040 & 17.0423342 & 0.195667 & 0.525 & 0.142 & 1.22154 \\
\hline 91 & 10100003 & 338745 & 91.1539917 & 6.47 & 6.811667 & 1.979667 & 9.791328 \\
\hline 92 & 10100004 & 1379018 & 35.545667 & 0.193 & 0.358 & 0.093667 & 15.54354 \\
\hline 93 & 10100005 & 409176 & 38.2323329 & 2.201667 & 3.846667 & 1.070667 & 4.960599 \\
\hline 94 & 10110101 & 1758238 & 12.3453331 & 0.534 & 2.270667 & 0.509667 & 6.882939 \\
\hline 95 & 10110102 & 241127 & 6.61400032 & 0.727 & 3.228667 & 0.728 & 0.505712 \\
\hline 96 & 10110201 & 899431 & 38.3536682 & 18.00567 & 7.894666 & 2.819 & 10.93876 \\
\hline 97 & 10110202 & 309164 & 43.03333354 & 2.635 & 4.053667 & 1.368333 & 4.218779 \\
\hline 98 & 10110203 & 562825 & 102.83667 & 0.308 & 1.336 & 0.593667 & 18.35334 \\
\hline 99 & 10110204 & 225787 & 55.2419993 & 0.219 & 1.053333 & 0.341 & 3.95514 \\
\hline 100 & 10110205 & 467213 & 70.3276672 & 0.160333 & 0.697333 & 0.242667 & 10.41921 \\
\hline 101 & 10120101 & 269241 & 20.55566666 & 1.463 & 1.351667 & 0.523 & 1.754957 \\
\hline 102 & 10120102 & 128094 & 9.81666692 & 0.785667 & 1.629333 & 0.434333 & 0.398737 \\
\hline 103 & 10120103 & 372143 & 24.9046656 & 1.336333 & 2.457667 & 0.675667 & 2.938894 \\
\hline 104 & 10120104 & 281559 & 11.8106664 & 1.143667 & 1.998667 & 0.523 & 1.054477 \\
\hline 105 & 10120105 & 259767 & 22.8926646 & 3.171667 & 4.631334 & 1.314667 & 1.885702 \\
\hline 106 & 10120106 & 363248 & 29.2910004 & 2.974333 & 2.415333 & 0.773 & 3.37389 \\
\hline 107 & 10120107 & 431165 & 29.1143341 & 1.039 & 1.375333 & 0.440333 & 3.980553 \\
\hline 108 & 10120108 & 250749 & 42.4476649 & 11.23367 & 7.540333 & 2.163333 & 3.375099 \\
\hline 109 & 10120109 & 549986 & 77.1116638 & 13.99767 & 10.00567 & 2.759 & 13.44822 \\
\hline 110 & 10120110 & 185230 & 133.481669 & 4.48 & 4.601667 & 1.221667 & 7.840183 \\
\hline 111 & 10120111 & 408864 & 54.6719971 & 6.235667 & 7.321667 & 2.065 & 7.088216 \\
\hline 112 & 10120112 & 419775 & 115.409332 & 31.62966 & 16.80067 & 4.640667 & 15.3621 \\
\hline 113 & 10120113 & 479704 & 108.648661 & 17.85133 & 12.52767 & 3.327 & 16.52688 \\
\hline
\end{tabular}


TABLE E.1 (Cont.)

\begin{tabular}{|c|c|c|c|c|c|c|c|}
\hline Sub-basin & Huc \# & $\begin{array}{l}\text { Land Area } \\
\text { (ha) }\end{array}$ & $\begin{array}{c}\text { WYLD } \\
\text { (water yield) } \\
\text { mm (per year) }\end{array}$ & $\begin{array}{l}\text { SYLDtha } \\
\text { (TSS metric } \\
\text { ton/ha) } \\
\end{array}$ & $\begin{array}{c}\text { Tnkgha (TN } \\
\text { kg/ha) }\end{array}$ & $\begin{array}{c}\text { Tpkgha (TP } \\
\text { kg/ha) }\end{array}$ & $\begin{array}{l}\text { Flow } \\
(\mathrm{m} 3 / \mathrm{s}) \\
\end{array}$ \\
\hline 114 & 10120201 & 760758 & 29.6486664 & 1.586 & 2.771 & 0.775667 & 7.152289 \\
\hline 115 & 10120202 & 840817 & 182.326335 & 15.69933 & 15.07133 & 4.161333 & 48.61208 \\
\hline 116 & 10120203 & 272141 & 100.546672 & 40.439 & 14.36767 & 3.456 & 8.676719 \\
\hline 117 & 10130101 & 654456 & 22.0760015 & 1.317 & 4.874 & 1.128333 & 4.581357 \\
\hline 118 & 10130102 & 941810 & 55.1486715 & 2.43 & 5.146333 & 1.445667 & 16.46992 \\
\hline 119 & 10130103 & 941115 & 36.9573313 & 0.936667 & 4.359666 & 1.040667 & 11.02901 \\
\hline 120 & 10130104 & 268242 & 45.7236684 & 2.267333 & 7.474 & 1.827 & 3.889203 \\
\hline 121 & 10130105 & 992749 & 104.300334 & 9.547 & 8.649334 & 2.580333 & 32.83359 \\
\hline 122 & 10130106 & 421367 & 52.2639974 & 2.173 & 9.961667 & 2.368 & 6.983238 \\
\hline 123 & 10130201 & 648307 & 1.51000007 & 0.208333 & 0.931333 & 0.215667 & 0.310421 \\
\hline 124 & 10130202 & 444044 & 26.4390004 & 0.982667 & 3.337334 & 0.764 & 3.722755 \\
\hline 125 & 10130203 & 422977 & 26.804334 & 1.046667 & 4.558 & 1.089333 & 3.595134 \\
\hline 126 & 10130204 & 423454 & 13.6836675 & 0.625667 & 2.375667 & 0.599 & 1.837393 \\
\hline 127 & 10130205 & 462617 & 15.1643333 & 1.904333 & 6.192 & 1.523667 & 2.22453 \\
\hline 128 & 10130206 & 231727 & 15.6686656 & 0.369 & 1.676667 & 0.401 & 1.151336 \\
\hline 129 & 10130301 & 322700 & 36.9329987 & 2.317667 & 9.195333 & 1.991333 & 3.779258 \\
\hline 130 & 10130302 & 451860 & 24.6993332 & 1.718 & 4.072667 & 0.953333 & 3.539013 \\
\hline 131 & 10130303 & 620750 & 52.364329 & 4.9 & 12.60233 & 2.660333 & 10.30731 \\
\hline 132 & 10130304 & 262456 & 74.976003 & 15.45033 & 11.519 & 3.222 & 6.239831 \\
\hline 133 & 10130305 & 406127 & 79.6186676 & 14.291 & 11.15367 & 2.842667 & 10.25347 \\
\hline 134 & 10130306 & 688446 & 105.648336 & 10.31167 & 14.17367 & 3.742 & 23.06352 \\
\hline 135 & 10140101 & 1105273 & 143.520325 & 12.23833 & 13.20233 & 3.651334 & 50.30096 \\
\hline 136 & 10140102 & 822589 & 30.5559998 & 10.116 & 5.962666 & 1.736 & 7.970264 \\
\hline 137 & 10140103 & 217031 & 28.3776652 & 1.957333 & 4.820667 & 1.341333 & 1.952951 \\
\hline 138 & 10140104 & 179465 & 72.5393372 & 8.922667 & 11.027 & 2.741 & 4.128069 \\
\hline 139 & 10140105 & 301935 & 102.400004 & 10.18033 & 13.904 & 4.041333 & 9.804064 \\
\hline 140 & 10140201 & 980158 & 68.2976685 & 3.448333 & 2.785 & 0.989 & 21.22732 \\
\hline 141 & 10140202 & 630174 & 138.375336 & 10.49967 & 4.246667 & 1.681667 & 27.6511 \\
\hline 142 & 10140203 & 420972 & 58.4969991 & 1.093667 & 1.13 & 0.318333 & 7.808723 \\
\hline 143 & 10140204 & 545513 & 108.57666 & 15.023 & 11.94633 & 3.207333 & 18.7817 \\
\hline 144 & 10150001 & 213701 & 101.136332 & 9.908334 & 8.962667 & 2.300667 & 6.853431 \\
\hline 145 & 10150002 & 383846 & 5.39399974 & 0.684333 & 0.254 & 0.095667 & 0.65654 \\
\hline 146 & 10150003 & 1075327 & 45.308665 & 0.273667 & 0.142333 & 0.053 & 15.44953 \\
\hline 147 & 10150004 & 980931 & 134.003998 & 0.030333 & 0.098667 & 0.029667 & 41.68211 \\
\hline 148 & 10150005 & 223182 & 148.492666 & 0.000667 & 0.002333 & 0.001 & 10.50889 \\
\hline 149 & 10150006 & 446424 & 89.782664 & 0.166667 & 0.511 & 0.147 & 12.70963 \\
\hline 150 & 10150007 & 386390 & 185.29067 & 7.598333 & 9.001 & 2.416667 & 22.70247 \\
\hline 151 & 10160001 & 439652 & 40.7283325 & 0.984 & 8.613 & 1.759333 & 5.678044 \\
\hline 152 & 10160002 & 277250 & 32.5049998 & 1.489 & 9.041666 & 2.117 & 2.857693 \\
\hline
\end{tabular}


TABLE E.1 (Cont.)

\begin{tabular}{|c|c|c|c|c|c|c|c|}
\hline Sub-basin & Huc \# & $\begin{array}{l}\text { Land Area } \\
\text { (ha) }\end{array}$ & $\begin{array}{c}\text { WYLD } \\
\text { (water yield) } \\
\text { mm (per year) }\end{array}$ & $\begin{array}{l}\text { SYLDtha } \\
\text { (TSS metric } \\
\text { ton/ha) } \\
\end{array}$ & $\begin{array}{c}\text { Tnkgha (TN } \\
\text { kg/ha) }\end{array}$ & $\begin{array}{c}\text { Tpkgha (TP } \\
\text { kg/ha) }\end{array}$ & $\begin{array}{l}\text { Flow } \\
(\mathrm{m} 3 / \mathrm{s}) \\
\end{array}$ \\
\hline 153 & 10160003 & 1158335 & 45.5726674 & 0.971 & 7.935667 & 1.688 & 16.7391 \\
\hline 154 & 10160004 & 401043 & 45.3683319 & 1.039 & 7.949334 & 1.734333 & 5.769487 \\
\hline 155 & 10160005 & 217091 & 94.5526733 & 4.928 & 30.87666 & 6.718 & 6.508927 \\
\hline 156 & 10160006 & 960379 & 60.1019999 & 1.537667 & 8.698333 & 2.182333 & 18.30311 \\
\hline 157 & 10160007 & 248041 & 37.6549988 & 1.221333 & 7.620667 & 1.846 & 2.961688 \\
\hline 158 & 10160008 & 440923 & 11.6879997 & 0.377 & 2.951333 & 0.634333 & 1.634167 \\
\hline 159 & 10160009 & 388712 & 14.8653336 & 0.346 & 1.810333 & 0.553667 & 1.832299 \\
\hline 160 & 10160011 & 942856 & 60.2853292 & 1.569333 & 8.334 & 2.162333 & 18.02396 \\
\hline 161 & 10170101 & 836348 & 101.731333 & 10.74667 & 20.43333 & 5.659667 & 26.97957 \\
\hline 162 & 10170102 & 548751 & 79.206665 & 3.255667 & 16.40433 & 4.121333 & 13.78259 \\
\hline 163 & 10170103 & 123793 & 68.3550008 & 3.468667 & 17.71133 & 4.173333 & 2.683233 \\
\hline 1 & 10170201 & 422955 & 67.9926656 & 1.225333 & 9.888333 & 2.304333 & 9.119044 \\
\hline 2 & 10170202 & 547369 & 153.664998 & 4.269334 & 23.438 & 5.546667 & 26.67155 \\
\hline 3 & 10170203 & 885453 & 132.513 & 3.363333 & 18.00667 & 4.726 & 37.2064 \\
\hline 4 & 10170204 & 434870 & 148.196004 & 5.476334 & 27.02633 & 7.054333 & 20.43571 \\
\hline 5 & 10180001 & 368937 & 24.8176676 & 0.006 & 0.138667 & 0.013333 & 2.903396 \\
\hline 6 & 10180002 & 766577 & 13.4246674 & 0.001 & 0.105 & 0.003 & 3.263269 \\
\hline 7 & 10180003 & 266936 & 9.41366641 & 0.000333 & 0.003333 & 0 & 0.796817 \\
\hline 8 & 10180004 & 373345 & 4.311333334 & 0 & 0.009 & 0.000333 & 0.510406 \\
\hline 9 & 10180005 & 265053 & 2.2863334 & 0.000333 & 0.002 & 0 & 0.192161 \\
\hline 10 & 10180006 & 751384 & 3.639666888 & 0 & 0.002333 & 0 & 0.867195 \\
\hline 11 & 10180007 & 899646 & 10.3536669 & 0.001 & 0.007333 & 0 & 2.95365 \\
\hline 12 & 10180008 & 551033 & 34.0356649 & 0.005333 & 0.105 & 0.002667 & 5.947099 \\
\hline 13 & 10180009 & 1335159 & 35.9013316 & 0 & 0 & 0 & 15.19977 \\
\hline 14 & 10180010 & 588624 & 5.65600014 & 0 & 0 & 0 & 1.0557 \\
\hline 15 & 10180011 & 604653 & 46.2870026 & 0.000333 & 0.002 & 0 & 8.874808 \\
\hline 16 & 10180012 & 441324 & 17.8656667 & 0.001333 & 0.005667 & 0.000667 & 2.500176 \\
\hline 17 & 10180013 & 266355 & 22.2263336 & 0.003 & 0.034333 & 0.001667 & 1.877246 \\
\hline 18 & 10180014 & 568481 & 144.698669 & 0.001333 & 0.013667 & 0.004333 & 26.084 \\
\hline 19 & 10190001 & 415504 & 36.3366648 & 0.000333 & 0.015 & 0.000667 & 4.787549 \\
\hline 20 & 10190002 & 479080 & 120.799662 & 0.012 & 0.997667 & 0.086333 & 18.3513 \\
\hline 21 & 10190003 & 745569 & 7.32533264 & 0.001 & 0.017333 & 0.004667 & 1.731842 \\
\hline 22 & 10190004 & 146538 & 191.954997 & 0.013667 & 1.265667 & 0.094667 & 8.919561 \\
\hline 23 & 10190005 & 253615 & 95.3730062 & 0.065333 & 0.325667 & 0.058667 & 7.669964 \\
\hline 24 & 10190006 & 215476 & 75.633667 & 0.019 & 0.099 & 0.017 & 5.167826 \\
\hline 25 & 10190007 & 489640 & 70.8796692 & 0.005 & 0.030333 & 0.004667 & 11.00505 \\
\hline 26 & 10190008 & 149689 & 23.1096675 & 0 & 0.003667 & 0 & 1.096928 \\
\hline 27 & 10190009 & 359954 & 1.259333329 & 0 & 0 & 0 & 0.143741 \\
\hline 28 & 10190010 & 185646 & 7.4873333 & 0.076333 & 0.298333 & 0.057333 & 0.440765 \\
\hline
\end{tabular}


TABLE E.1 (Cont.)

\begin{tabular}{|c|c|c|c|c|c|c|c|}
\hline Sub-basin & Huc \# & $\begin{array}{l}\text { Land Area } \\
\text { (ha) }\end{array}$ & $\begin{array}{c}\text { WYLD } \\
\text { (water yield) } \\
\text { mm (per year) }\end{array}$ & $\begin{array}{c}\text { SYLDtha } \\
\text { (TSS metric } \\
\text { ton/ha) } \\
\end{array}$ & $\begin{array}{c}\text { Tnkgha (TN } \\
\text { kg/ha) }\end{array}$ & $\begin{array}{c}\text { Tpkgha (TP } \\
\text { kg/ha) }\end{array}$ & $\begin{array}{l}\text { Flow } \\
(\mathrm{m} 3 / \mathrm{s})\end{array}$ \\
\hline 29 & 10190011 & 358372 & 13.9626668 & 0.057 & 0.234333 & 0.045667 & 1.586706 \\
\hline 30 & 10190012 & 772547 & 12.5856667 & 0.024 & 0.149333 & 0.021 & 3.083149 \\
\hline 31 & 10190013 & 286559 & 4.3793335 & 0.023667 & 0.123333 & 0.020667 & 0.397938 \\
\hline 32 & 10190014 & 187442 & 0.84766666 & 0.000667 & 0.015667 & 0.001333 & 0.050383 \\
\hline 33 & 10190015 & 306258 & 8.15233358 & 0.000333 & 0.000667 & 0 & 0.791704 \\
\hline 34 & 10190016 & 345539 & 5.20366669 & 0.002 & 0.016 & 0.004 & 0.570165 \\
\hline 35 & 10190017 & 194764 & 2.95600001 & 0 & 0 & 0 & 0.182561 \\
\hline 36 & 10190018 & 365743 & 60.5676676 & 0.039 & 0.251667 & 0.086667 & 7.024409 \\
\hline 37 & 10200101 & 865092 & 154.839661 & 0.962 & 4.473667 & 1.727333 & 42.47543 \\
\hline 38 & 10200102 & 189153 & 95 & 1.071333 & 4.816333 & 1.525667 & 5.698089 \\
\hline 39 & 10200103 & 285443 & 183.743327 & 1.002333 & 8.882667 & 2.582667 & 16.63125 \\
\hline 40 & 10200201 & 222283 & 123.02533 & 7.104666 & 24.29667 & 8.725333 & 8.6715 \\
\hline 41 & 10200202 & 135965 & 194.200684 & 8.238667 & 27.72667 & 8.91 & 8.372784 \\
\hline 42 & 10200203 & 426642 & 192.452332 & 6.763334 & 24.68233 & 7.621667 & 26.03635 \\
\hline 43 & 10210001 & 541456 & 196.717672 & 0 & 0 & 0 & 33.77537 \\
\hline 44 & 10210002 & 469579 & 209.093994 & 0 & 0.004333 & 0.001333 & 31.13463 \\
\hline 45 & 10210003 & 462816 & 178.407328 & 2.812667 & 7.462334 & 3.277 & 26.1827 \\
\hline 46 & 10210004 & 409430 & 158.411001 & 3.334 & 9.432667 & 3.264 & 20.56642 \\
\hline 47 & 10210005 & 191857 & 169.289001 & 3.457 & 9.101333 & 3.592 & 10.29914 \\
\hline 48 & 10210006 & 608494 & 159.51767 & 0.001 & 0.015667 & 0.003333 & 30.77927 \\
\hline 49 & 10210007 & 253275 & 143.195333 & 1.378667 & 5.792 & 2.285 & 11.50046 \\
\hline 50 & 10210008 & 256752 & 222.129679 & 0.001667 & 0.01 & 0.005333 & 18.0848 \\
\hline 51 & 10210009 & 397219 & 190.913005 & 6.497667 & 19.62467 & 9.605 & 24.04691 \\
\hline 52 & 10210010 & 318554 & 232.572673 & 1.230333 & 4.435333 & 2.066 & 23.49283 \\
\hline 53 & 10220001 & 749227 & 193.914998 & 1.456667 & 5.123 & 2.699 & 46.07002 \\
\hline 54 & 10220002 & 219779 & 146.671326 & 0.720667 & 3.826 & 1.596667 & 10.22175 \\
\hline 55 & 10220003 & 571508 & 123.545329 & 7.036 & 24.488 & 11.74967 & 22.38936 \\
\hline 56 & 10220004 & 272753 & 168.721334 & 12.62967 & 41.99233 & 16.376 & 14.59258 \\
\hline 57 & 10230001 & 416671 & 250.713664 & 9.569 & 32.48333 & 9.280667 & 33.12566 \\
\hline 58 & 10230002 & 237228 & 63.4639994 & 0.647333 & 4.359666 & 1.35 & 4.774044 \\
\hline 59 & 10230003 & 733458 & 247.38798 & 3.467 & 19.17733 & 5.443333 & 57.537 \\
\hline 60 & 10230004 & 250251 & 255.893677 & 11.079 & 33.239 & 7.413667 & 20.30622 \\
\hline 61 & 10230005 & 191639 & 225.778341 & 16.01067 & 45.48 & 13.383 & 13.72021 \\
\hline 62 & 10230006 & 288480 & 339.835002 & 17.47833 & 34.16 & 10.024 & 31.08694 \\
\hline 63 & 10230007 & 308196 & 350.877686 & 44.076 & 71.24233 & 17.46 & 34.29065 \\
\hline 64 & 10240001 & 217036 & 351.139648 & 20.563 & 45.807 & 12.199 & 24.16602 \\
\hline 65 & 10240002 & 427746 & 432.912679 & 53.586 & 73.24266 & 19.01233 & 58.71909 \\
\hline 66 & 10240003 & 297519 & 417.768677 & 41.494 & 65.062 & 17.31333 & 39.41337 \\
\hline 67 & 10240004 & 45333 & 358.501343 & 16.79133 & 37.453 & 9.025333 & 5.153424 \\
\hline
\end{tabular}


TABLE E.1 (Cont.)

\begin{tabular}{|c|c|c|c|c|c|c|c|}
\hline Sub-basin & Huc \# & $\begin{array}{l}\text { Land Area } \\
\text { (ha) }\end{array}$ & $\begin{array}{c}\text { WYLD } \\
\text { (water yield) } \\
\text { mm (per year) }\end{array}$ & $\begin{array}{l}\text { SYLDtha } \\
\text { (TSS metric } \\
\text { ton/ha) } \\
\end{array}$ & $\begin{array}{c}\text { Tnkgha (TN } \\
\text { kg/ha) }\end{array}$ & $\begin{array}{c}\text { Tpkgha (TP } \\
\text { kg/ha) }\end{array}$ & $\begin{array}{l}\text { Flow } \\
(\mathrm{m} 3 / \mathrm{s}) \\
\end{array}$ \\
\hline 68 & 10240005 & 440532 & 225.460002 & 5.926 & 25.65467 & 6.843667 & 31.49492 \\
\hline 69 & 10240006 & 231202 & 346.865682 & 16.259 & 37.85 & 9.522333 & 25.43003 \\
\hline 70 & 10240007 & 184138 & 415.317017 & 6.649666 & 15.58267 & 4.036667 & 24.25029 \\
\hline 71 & 10240008 & 313295 & 410.520671 & 12.263 & 27.75433 & 7.523333 & 40.78327 \\
\hline 72 & 10240009 & 205910 & 462.146647 & 25.854 & 52.74267 & 12.23633 & 30.17527 \\
\hline 73 & 10240010 & 258817 & 242.525675 & 7.536333 & 24.152 & 6.022667 & 19.90419 \\
\hline 74 & 10240011 & 269962 & 296.298014 & 2.289 & 5.423 & 2.36 & 25.36446 \\
\hline 75 & 10240012 & 431051 & 264.837687 & 8.507001 & 17.214 & 2.316667 & 36.19947 \\
\hline 76 & 10240013 & 201147 & 442.095337 & 18.718 & 29.922 & 4.155 & 28.19827 \\
\hline 77 & 10250001 & 478365 & 18.4906667 & 0.051333 & 0.269 & 0.042333 & 2.804823 \\
\hline 78 & 10250002 & 763693 & 14.9860001 & 0.007 & 0.037333 & 0.005667 & 3.629091 \\
\hline 79 & 10250003 & 698728 & 1.49866676 & 0.064 & 0.299667 & 0.045 & 0.332052 \\
\hline 80 & 10250004 & 558122 & 0.638333336 & 0.045333 & 0.194667 & 0.042 & 0.112972 \\
\hline 81 & 10250005 & 426612 & 13.1786664 & 0.065 & 0.600333 & 0.116 & 1.782779 \\
\hline 82 & 10250006 & 374504 & 49.7319997 & 0.387667 & 2.127 & 0.408 & 5.905897 \\
\hline 83 & 10250007 & 205533 & 39.481664 & 0.053 & 0.257667 & 0.079 & 2.573178 \\
\hline 84 & 10250008 & 240209 & 75.5706635 & 0.497667 & 1.544333 & 0.444667 & 5.756198 \\
\hline 85 & 10250009 & 349396 & 47.6640015 & 1.252667 & 3.81 & 1.012 & 5.280818 \\
\hline 86 & 10250010 & 274769 & 5.27399985 & 0.066333 & 0.349333 & 0.094667 & 0.459516 \\
\hline 87 & 10250011 & 169184 & 9.06200027 & 0.345 & 1.136667 & 0.334667 & 0.486158 \\
\hline 88 & 10250012 & 194627 & 1.28299999 & 0.039667 & 0.146 & 0.053333 & 0.079181 \\
\hline 89 & 10250013 & 166616 & 0.061 & 0 & 0.001333 & 0 & 0.003223 \\
\hline 90 & 10250014 & 189660 & 3.32833354 & 0.254 & 0.793667 & 0.193333 & 0.200169 \\
\hline 91 & 10250015 & 287198 & 21.2700005 & 0.298333 & 0.979667 & 0.269667 & 1.937057 \\
\hline 92 & 10250016 & 562392 & 59.7826691 & 0.584 & 2.544333 & 0.763667 & 10.66124 \\
\hline 93 & 10250017 & 512540 & 34.811999 & 0.747667 & 2.807 & 0.620333 & 5.657828 \\
\hline 94 & 10260001 & 272661 & 11.072333 & 0 & 0.001 & 0 & 0.957318 \\
\hline 95 & 10260002 & 188982 & 0.042 & 0 & 0 & 0 & 0.002517 \\
\hline 96 & 10260003 & 382882 & 0.09733333 & 0.001333 & 0.004667 & 0.001 & 0.011817 \\
\hline 97 & 10260004 & 366904 & 0.051 & 0 & 0 & 0 & 0.005934 \\
\hline 98 & 10260005 & 168003 & 0.035 & 0.000333 & 0.000667 & 0 & 0.001865 \\
\hline 99 & 10260006 & 408990 & 105.412669 & 0.002333 & 0.037 & 0.010667 & 13.67094 \\
\hline 100 & 10260007 & 223171 & 59.7690023 & 0.010667 & 0.077333 & 0.022333 & 4.229684 \\
\hline 101 & 10260008 & 517408 & 207.582662 & 0.771 & 2.661 & 0.597333 & 34.0579 \\
\hline 102 & 10260009 & 497613 & 30.2670008 & 0.041333 & 0.094 & 0.032667 & 4.775891 \\
\hline 103 & 10260010 & 352475 & 108.786997 & 0.022 & 0.085667 & 0.014333 & 12.15903 \\
\hline 104 & 10260011 & 363457 & 25.1176682 & 0.001 & 0.002667 & 0.000667 & 2.894847 \\
\hline 105 & 10260012 & 348012 & 81.4473368 & 0.244 & 1.022667 & 0.218333 & 8.988019 \\
\hline 106 & 10260013 & 299656 & 53.9293315 & 0.031667 & 0.080333 & 0.026 & 5.124375 \\
\hline
\end{tabular}


TABLE E.1 (Cont.)

\begin{tabular}{|c|c|c|c|c|c|c|c|}
\hline Sub-basin & Huc \# & $\begin{array}{l}\text { Land Area } \\
\text { (ha) }\end{array}$ & $\begin{array}{c}\text { WYLD } \\
\text { (water yield) } \\
\text { mm (per year) }\end{array}$ & $\begin{array}{l}\text { SYLDtha } \\
\text { (TSS metric } \\
\text { ton/ha) } \\
\end{array}$ & $\begin{array}{c}\text { Tnkgha (TN } \\
\text { kg/ha) }\end{array}$ & $\begin{array}{c}\text { Tpkgha (TP } \\
\text { kg/ha) }\end{array}$ & $\begin{array}{l}\text { Flow } \\
(\mathrm{m} 3 / \mathrm{s})\end{array}$ \\
\hline 107 & 10260014 & 275480 & 110.780334 & 0.055 & 0.184333 & 0.037333 & 9.677132 \\
\hline 108 & 10260015 & 491287 & 38.5766652 & 0.015333 & 0.072 & 0.018333 & 6.009705 \\
\hline 109 & 10270101 & 138965 & 325.340658 & 1.004 & 3.877 & 0.850333 & 14.33634 \\
\hline 110 & 10270102 & 564784 & 343.839315 & 1.057 & 4.742333 & 1.119667 & 61.57882 \\
\hline 111 & 10270103 & 299650 & 296.322673 & 3.953667 & 9.379667 & 2.348 & 28.15613 \\
\hline 112 & 10270104 & 428771 & 368.809001 & 3.042 & 7.934333 & 2.163 & 50.1442 \\
\hline 113 & 10270201 & 286881 & 102.057332 & 2.366333 & 14.01967 & 4.095667 & 9.284076 \\
\hline 114 & 10270202 & 327311 & 213.942668 & 5.139333 & 18.19667 & 5.125667 & 22.20505 \\
\hline 115 & 10270203 & 347071 & 123.301331 & 2.522 & 16.385 & 4.353333 & 13.56997 \\
\hline 116 & 10270204 & 188718 & 174.01534 & 3.809 & 17.78467 & 4.716 & 10.41345 \\
\hline 117 & 10270205 & 441986 & 287.161336 & 6.024334 & 14.31667 & 4.549 & 40.2465 \\
\hline 118 & 10270206 & 582064 & 98.0590007 & 0.796 & 5.681667 & 1.399667 & 18.09888 \\
\hline 119 & 10270207 & 346940 & 224.42334 & 2.750667 & 9.587667 & 2.529667 & 24.68973 \\
\hline 120 & 10280101 & 861417 & 265.377991 & 8.475 & 27.169 & 4.985667 & 72.48897 \\
\hline 121 & 10280102 & 570092 & 396.14799 & 10.38533 & 28.302 & 5.471 & 71.61361 \\
\hline 122 & 10280103 & 611445 & 417.923014 & 4.333667 & 16.50333 & 3.415333 & 81.03029 \\
\hline 123 & 10280201 & 350227 & 362.61499 & 10.045 & 21.3 & 4.646667 & 40.27064 \\
\hline 124 & 10280202 & 264085 & 526.642008 & 3.590333 & 14.41533 & 3.287667 & 44.10139 \\
\hline 125 & 10280203 & 180960 & 455.301351 & 4.534334 & 13.06467 & 2.912333 & 26.12605 \\
\hline 126 & 10290101 & 563677 & 480.361979 & 4.601333 & 10.24733 & 2.417 & 85.8603 \\
\hline 127 & 10290102 & 408239 & 594.431315 & 5.859 & 15.34567 & 3.107333 & 76.95013 \\
\hline 128 & 10290103 & 150442 & 575.188354 & 3.964 & 11.532 & 2.369667 & 27.4393 \\
\hline 129 & 10290104 & 295566 & 544.10498 & 4.171333 & 10.21933 & 2.056667 & 50.99541 \\
\hline 130 & 10290105 & 311722 & 351.919027 & 1.814667 & 5.227667 & 1.209667 & 34.78588 \\
\hline 131 & 10290106 & 510403 & 495.225993 & 0.379667 & 2.380333 & 0.438333 & 80.15127 \\
\hline 132 & 10290107 & 219065 & 509.797038 & 1.588 & 3.87 & 0.545 & 35.41303 \\
\hline 133 & 10290108 & 530223 & 386.791016 & 3.950666 & 15.131 & 2.728 & 65.03215 \\
\hline 134 & 10290109 & 359147 & 467.068685 & 0.382 & 2.069333 & 0.32 & 53.192 \\
\hline 135 & 10290110 & 266605 & 598.426025 & 3.704667 & 5.121667 & 0.698333 & 50.59094 \\
\hline 136 & 10290111 & 279140 & 481.036662 & 1.812 & 5.278667 & 0.808667 & 42.57886 \\
\hline 137 & 10290201 & 463009 & 677.220662 & 2.143 & 6.665 & 0.841333 & 99.42898 \\
\hline 138 & 10290202 & 195588 & 614.182007 & 2.015 & 4.877666 & 0.632 & 38.09196 \\
\hline 139 & 10290203 & 267580 & 490.132324 & 1.402333 & 4.762333 & 0.668333 & 41.58728 \\
\hline 140 & 10300101 & 699076 & 371.76001 & 3.583 & 10.41967 & 2.763333 & 82.41013 \\
\hline 141 & 10300102 & 880813 & 386.967 & 1.655667 & 4.950333 & 1.411 & 108.0814 \\
\hline 142 & 10300103 & 287938 & 345.487345 & 4.453334 & 11.91167 & 3.070333 & 31.5446 \\
\hline 143 & 10300104 & 399991 & 357.907308 & 12.17467 & 22.09233 & 6.206 & 45.39567 \\
\hline 144 & 10300200 & 411954 & 592.156006 & 1.208 & 5.965333 & 1.419667 & 77.35313 \\
\hline
\end{tabular}


TABLE E.2 Land use.

\begin{tabular}{|c|c|c|c|c|c|c|}
\hline Huc \# & $\begin{array}{c}\text { WHEAT_SUM } \\
\text { (ha) }\end{array}$ & $\begin{array}{c}\text { SOYB_SUM } \\
\text { (ha) }\end{array}$ & $\begin{array}{c}\text { CORN_SUM } \\
\text { (ha) }\end{array}$ & $\begin{array}{c}\text { Pasture Land Area } \\
\text { HAY/PAST/GRASS_SUM } \\
\text { (ha) }\end{array}$ & $\begin{array}{c}\text { Other } \\
\text { Agricultural } \\
\text { Land Area } \\
\text { (ha) } \\
\end{array}$ & $\begin{array}{c}\text { Idle } \\
\text { Land/CRP } \\
\text { (ha) } \\
\end{array}$ \\
\hline 10020001 & 6.480042 & 0 & 0 & 318072.8 & 0 & 4.68 \\
\hline 10020002 & 6270.161 & 0 & 33.84022 & 245365.5 & 0 & 114.12 \\
\hline 10020003 & 384.4825 & 0 & 7.560049 & 121888 & 0 & 9 \\
\hline 10020004 & 104.7607 & 0 & 3.240021 & 283956.8 & 0 & 89.28 \\
\hline 10020005 & 2404.816 & 0 & 34.56023 & 185953.3 & 0 & 705.6 \\
\hline 10020006 & 172.4411 & 0 & 3.240021 & 53727.06 & 0 & 29.88 \\
\hline 10020007 & 895.6858 & 0 & 4.68003 & 180730.6 & 0 & 422.28 \\
\hline 10020008 & 14999.86 & 0 & 189.7212 & 152720.7 & 0 & 2360.9 \\
\hline 10030101 & 10611.07 & 0 & 82.08054 & 354267 & 0 & 4325.43 \\
\hline 10030102 & 77819.91 & 0 & 20.88014 & 398604.6 & 0 & 41984.55 \\
\hline 10030103 & 2856.619 & 0 & 1.080007 & 268770.7 & 0 & 511.2 \\
\hline 10030104 & 20802.74 & 0 & 16.92011 & 271819.1 & 0 & 7839.77 \\
\hline 10030105 & 7600.73 & 0 & 0 & 91358.58 & 0 & 3486.98 \\
\hline 10030201 & 8568.416 & 0 & 2.520016 & 190559.7 & 0 & 4720.71 \\
\hline 10030202 & 38913.01 & 0 & 2.520016 & 235137.6 & 21754.65 & 20209.45 \\
\hline 10030203 & 218229.1 & 0.720005 & 465.483 & 589589.5 & 0 & 169615.1 \\
\hline 10030204 & 56303.29 & 0 & 10.80007 & 157844.8 & 0 & 47767.99 \\
\hline 10030205 & 86989.89 & 0 & 59.40039 & 361308.8 & 0 & 64890.78 \\
\hline 10040101 & 46495.02 & 0 & 2.880019 & 345967.3 & 0 & 32824.65 \\
\hline 10040102 & 32202.57 & 0 & 6.480042 & 267706.8 & 0 & 16660.55 \\
\hline 10040103 & 67312.52 & 0 & 9.720063 & 434048.7 & 0 & 18239.52 \\
\hline 10040104 & 8817.897 & 0 & 28.44019 & 956811.2 & 0 & 5910.52 \\
\hline 10040105 & 12039.56 & 0 & 2.160014 & 383416.9 & 0 & 9563.1 \\
\hline 10040106 & 12750.56 & 0 & 73.44048 & 294694.3 & 0 & 10531.87 \\
\hline 10040201 & 20769.62 & 0 & 32.76021 & 760257.9 & 0 & 9904.74 \\
\hline 10040202 & 6733.484 & 0 & 54.36035 & 409353.7 & 0 & 1240.57 \\
\hline 10040203 & 2071.813 & 0 & 3.960026 & 130386.5 & 0 & 823.33 \\
\hline 10040204 & 4676.79 & 0 & 2.160014 & 248922.1 & 0 & 2932.22 \\
\hline 10040205 & 3821.785 & 0 & 1.800012 & 343684 & 0 & 1672.21 \\
\hline 10050001 & 5135.073 & 0 & 0 & 222389.3 & 0 & 2494.46 \\
\hline 10050002 & 52242.82 & 0 & 21.24014 & 500415.9 & 0 & 39122.54 \\
\hline 10050003 & 1263.248 & 0 & 1.080007 & 119247.5 & 0 & 1663.21 \\
\hline 10050004 & 82243.98 & 1.080007 & 81.00053 & 784879.3 & 0 & 57376.45 \\
\hline 10050005 & 46925.23 & 0 & 2.880019 & 102127.5 & 0 & 36152.52 \\
\hline 10050006 & 70096.78 & 0 & 69.84045 & 150731.9 & 0 & 43233.4 \\
\hline 10050007 & 10207.87 & 0 & 8.640056 & 264401.9 & 0 & 9124.98 \\
\hline 10050008 & 4657.35 & 0 & 1.800012 & 437539.3 & 0 & 3629.9 \\
\hline 10050009 & 8036.692 & 0 & 0.360002 & 146219.4 & 0 & 4383.75 \\
\hline 10050010 & 26625.41 & 0 & 2.520016 & 206058.9 & 0 & 16434.47 \\
\hline
\end{tabular}


TABLE E.2 (Cont.)

\begin{tabular}{|c|c|c|c|c|c|c|}
\hline Huc \# & $\begin{array}{l}\text { WHEAT_SUM } \\
\text { (ha) }\end{array}$ & $\begin{array}{l}\text { SOYB_SUM } \\
\text { (ha) }\end{array}$ & $\begin{array}{c}\text { CORN_SUM } \\
\text { (ha) }\end{array}$ & $\begin{array}{c}\text { Pasture Land Area } \\
\text { HAY/PAST/GRASS_SUM } \\
\text { (ha) }\end{array}$ & $\begin{array}{c}\text { Other } \\
\text { Agricultural } \\
\text { Land Area } \\
\text { (ha) }\end{array}$ & $\begin{array}{c}\text { Idle } \\
\text { Land/CRP } \\
\text { (ha) }\end{array}$ \\
\hline 10050011 & 8014.732 & 0 & 1.080007 & 457521.6 & 0 & 4179.63 \\
\hline 10050012 & 21455.42 & 1.080007 & 219.9614 & 370450.7 & 0 & 8757.78 \\
\hline 10050013 & 1009.807 & 0 & 1.440009 & 618805.2 & 0 & 363.6 \\
\hline 10050014 & 13213.53 & 0.720005 & 25.92017 & 462711 & 0 & 4377.63 \\
\hline 10050015 & 3828.985 & 0 & 0.360002 & 351079.7 & 0 & 975.97 \\
\hline 10050016 & 34543.67 & 0 & 7.920052 & 161978 & 0 & 5884.24 \\
\hline 10060001 & 72153.47 & 1.440009 & 704.5246 & 437943.6 & 0 & 20158.33 \\
\hline 10060002 & 95107.22 & 0 & 161.2811 & 442622.5 & 0 & 27082.62 \\
\hline 10060003 & 87797.37 & 0 & 57.24037 & 510194.6 & 0 & 19052.4 \\
\hline 10060004 & 48818.84 & 0 & 7.560049 & 235270.5 & 0 & 4419.75 \\
\hline 10060005 & 37406.76 & 0.360002 & 1219.688 & 285099.9 & 0 & 7331.45 \\
\hline 10060006 & 186470.1 & 0 & 586.8038 & 716195.9 & 0 & 17767.92 \\
\hline 10060007 & 44912.09 & 0 & 399.2426 & 220717.8 & 0 & 4178.55 \\
\hline 10070001 & 0.720005 & 0 & 0.720005 & 45832.89 & 0 & 50.4 \\
\hline 10070002 & 594.7239 & 0 & 29.88019 & 301125.6 & 0 & 42.48 \\
\hline 10070003 & 1121.047 & 0 & 2.520016 & 110737 & 0 & 271.44 \\
\hline 10070004 & 11880.08 & 0 & 2630.177 & 290934.9 & 0 & 5522.08 \\
\hline 10070005 & 100.0807 & 0 & 6.480042 & 115156.4 & 0 & 26.64 \\
\hline 10070006 & 2327.055 & 0 & 2249.295 & 231384.9 & 0 & 771.49 \\
\hline 10070007 & 19756.57 & 0 & 2396.176 & 409555.1 & 0 & 10670.47 \\
\hline 10070008 & 7315.248 & 0 & 10.08007 & 67507.33 & 0 & 1911.97 \\
\hline 10080001 & 201.9613 & 0 & 336.9622 & 118042.8 & 0 & 61.92 \\
\hline 10080002 & 68.04045 & 0 & 69.48045 & 47097.05 & 0 & 75.6 \\
\hline 10080003 & 28.44019 & 0 & 9.720064 & 31460.37 & 0 & 26.64 \\
\hline 10080004 & 1.080007 & 0 & 0 & 31646.47 & 0 & 0.72 \\
\hline 10080005 & 641.5242 & 0 & 1091.887 & 127489.8 & 0 & 202.32 \\
\hline 10080006 & 6.840044 & 0 & 0 & 66194.18 & 0 & 17.28 \\
\hline 10080007 & 434.1628 & 0 & 2550.977 & 317478.2 & 0 & 478.08 \\
\hline 10080008 & 90.72059 & 0 & 168.1211 & 150818.9 & 0 & 44.64 \\
\hline 10080009 & 613.084 & 0 & 1211.408 & 96881.24 & 0 & 990.01 \\
\hline 10080010 & 227.8815 & 0 & 425.5228 & 157742.7 & 0 & 506.16 \\
\hline 10080011 & 118.4408 & 0 & 198.0013 & 41590.13 & 0 & 199.44 \\
\hline 10080012 & 0 & 0 & 0 & 45023.52 & 0 & 2.88 \\
\hline 10080013 & 17.28011 & 0 & 1.080007 & 57474.09 & 0 & 15.84 \\
\hline 10080014 & 1351.449 & 0 & 2447.656 & 159918.6 & 25199.79 & 1093.33 \\
\hline 10080015 & 21686.54 & 0 & 1032.847 & 317184.6 & 0 & 6438.64 \\
\hline 10080016 & 4021.946 & 0 & 359.2824 & 138251.4 & 0 & 1074.25 \\
\hline 10090101 & 5696.317 & 0 & 315.3621 & 294911.4 & 0 & 316.08 \\
\hline 10090102 & 957.2462 & 0 & 1027.447 & 379139.5 & 0 & 309.96 \\
\hline
\end{tabular}


TABLE E.2 (Cont.)

\begin{tabular}{|c|c|c|c|c|c|c|}
\hline Huc \# & $\begin{array}{l}\text { WHEAT_SUM } \\
\text { (ha) }\end{array}$ & $\begin{array}{c}\text { SOYB_SUM } \\
\text { (ha) }\end{array}$ & $\begin{array}{c}\text { CORN_SUM } \\
\text { (ha) }\end{array}$ & $\begin{array}{c}\text { Pasture Land Area } \\
\text { HAY/PAST/GRASS_SUM } \\
\text { (ha) }\end{array}$ & $\begin{array}{c}\text { Other } \\
\text { Agricultural } \\
\text { Land Area } \\
\text { (ha) }\end{array}$ & $\begin{array}{c}\text { Idle } \\
\text { Land/CRP } \\
\text { (ha) }\end{array}$ \\
\hline 10090201 & 28.80019 & 0 & 6.840045 & 84673.9 & 0 & 9 \\
\hline 10090202 & 1224.368 & 0 & 52.92035 & 517144.5 & 0 & 1711.81 \\
\hline 10090203 & 147.601 & 0 & 0.720005 & 96293.77 & 0 & 729.72 \\
\hline 10090204 & 0.720005 & 0 & 0 & 90733.87 & 0 & 42.84 \\
\hline 10090205 & 36.00023 & 0 & 1.800012 & 132008.8 & 0 & 30.6 \\
\hline 10090206 & 110.1607 & 0 & 120.2408 & 190531.3 & 0 & 29.88 \\
\hline 10090207 & 512.6433 & 0 & 1.080007 & 157057.4 & 0 & 585 \\
\hline 10090208 & 2651.057 & 0 & 0.720005 & 380313.2 & 0 & 3174.14 \\
\hline 10090209 & 1613.171 & 0 & 46.0803 & 352891.4 & 0 & 803.53 \\
\hline 10090210 & 1209.968 & 0 & 22.32015 & 146668.7 & 0 & 655.56 \\
\hline 10100001 & 17386.31 & 0 & 5558.796 & 950639.3 & 0 & 8122.37 \\
\hline 10100002 & 1318.329 & 0 & 20.16013 & 224385.1 & 0 & 376.56 \\
\hline 10100003 & 244.4416 & 0 & 18.36012 & 128223.2 & 0 & 258.48 \\
\hline 10100004 & 114061 & 43.56028 & 4726.111 & 1253451 & 0 & 26872.38 \\
\hline 10100005 & 4344.148 & 0 & 119.1608 & 332591.6 & 0 & 1490.77 \\
\hline 10110101 & 385903.1 & 371.5224 & 8869.378 & 989825 & 194451 & 16516.91 \\
\hline 10110102 & 95327.18 & 0 & 481.6831 & 94256.19 & 31982.3 & 9526.02 \\
\hline 10110201 & 11658.32 & 0 & 132.1209 & 671687.8 & 0 & 3419.66 \\
\hline 10110202 & 5598.396 & 0 & 32.40021 & 234872.6 & 0 & 1091.17 \\
\hline 10110203 & 31899.45 & 0 & 2429.296 & 531300.5 & 0 & 993.61 \\
\hline 10110204 & 27658.98 & 0 & 2001.973 & 202058.2 & 0 & 2385.74 \\
\hline 10110205 & 18496.2 & 2.160014 & 436.6828 & 369795 & 0 & 1688.05 \\
\hline 10120101 & 0.360002 & 0 & 0.360002 & 186063.5 & 0 & 635.4 \\
\hline 10120102 & 0 & 0 & 0 & 99197.7 & 0 & 7.56 \\
\hline 10120103 & 5.400035 & 0 & 18.36012 & 276917.9 & 0 & 50.04 \\
\hline 10120104 & 105.8407 & 0 & 6.12004 & 221505.7 & 0 & 181.8 \\
\hline 10120105 & 14.40009 & 0 & 0 & 200765.5 & 0 & 56.52 \\
\hline 10120106 & 1516.69 & 1.080007 & 8.280054 & 309614.8 & 0 & 271.08 \\
\hline 10120107 & 420.4827 & 0 & 105.1207 & 215849.1 & 0 & 770.77 \\
\hline 10120108 & 176.4011 & 0 & 4.320028 & 251882.1 & 0 & 203.4 \\
\hline 10120109 & 1726.571 & 0 & 77.76051 & 374294.5 & 0 & 623.16 \\
\hline 10120110 & 2286.375 & 0 & 0.720005 & 82505.98 & 0 & 277.2 \\
\hline 10120111 & 20911.1 & 0.360002 & 155.521 & 315402.1 & 0 & 3772.1 \\
\hline 10120112 & 27919.98 & 0.360002 & 1404.369 & 388573.6 & 0 & 5967.4 \\
\hline 10120113 & 10084.39 & 0 & 310.322 & 475850 & 0 & 2570.42 \\
\hline 10120201 & 2033.293 & 0 & 7.920052 & 565046.3 & 0 & 7089.53 \\
\hline 10120202 & 7961.812 & 19.80013 & 2284.215 & 711089.3 & 0 & 3494.54 \\
\hline 10120203 & 453.603 & 0 & 39.96026 & 110482.3 & 0 & 284.04 \\
\hline 10130101 & 104092.5 & 1409.409 & 13434.21 & 495749.2 & 46678.89 & 1120.69 \\
\hline
\end{tabular}


TABLE E.2 (Cont.)

\begin{tabular}{|c|c|c|c|c|c|c|}
\hline Huc \# & $\begin{array}{l}\text { WHEAT_SUM } \\
\text { (ha) }\end{array}$ & $\begin{array}{l}\text { SOYB_SUM } \\
\text { (ha) }\end{array}$ & $\begin{array}{c}\text { CORN_SUM } \\
\text { (ha) }\end{array}$ & $\begin{array}{c}\text { Pasture Land Area } \\
\text { HAY/PAST/GRASS_SUM } \\
\text { (ha) }\end{array}$ & $\begin{array}{c}\text { Other } \\
\text { Agricultural } \\
\text { Land Area } \\
\text { (ha) }\end{array}$ & $\begin{array}{c}\text { Idle } \\
\text { Land/CRP } \\
\text { (ha) }\end{array}$ \\
\hline 10130102 & 75745.93 & 7511.089 & 30816.56 & 768108.4 & 0 & 1253.53 \\
\hline 10130103 & 73554.6 & 10993.75 & 26064.17 & 750135.9 & 0 & 875.53 \\
\hline 10130104 & 35211.47 & 2545.577 & 9661.743 & 205125.3 & 16599.02 & 225.36 \\
\hline 10130105 & 155232.7 & 16112.62 & 59787.75 & 682837.5 & 0 & 5006.19 \\
\hline 10130106 & 34399.66 & 15668.38 & 28375.03 & 319439.8 & 0 & 523.44 \\
\hline 10130201 & 95115.14 & 25.56017 & 6148.12 & 560583 & 0 & 1394.65 \\
\hline 10130202 & 119301.5 & 18.36012 & 6175.84 & 340848.8 & 0 & 442.44 \\
\hline 10130203 & 73071.84 & 70.92046 & 5755.717 & 352515.7 & 0 & 533.16 \\
\hline 10130204 & 143681.3 & 10.44007 & 4479.869 & 302338.3 & 0 & 705.96 \\
\hline 10130205 & 118924.3 & 12.24008 & 4824.751 & 371594.4 & 0 & 956.89 \\
\hline 10130206 & 9956.945 & 53.64035 & 1788.492 & 220743.7 & 0 & 213.84 \\
\hline 10130301 & 55167.48 & 1.080007 & 4236.868 & 274103.3 & 0 & 812.89 \\
\hline 10130302 & 15202.18 & 0.360002 & 1708.571 & 446268.6 & 0 & 481.32 \\
\hline 10130303 & 40160.42 & 1.080007 & 5582.196 & 591232.6 & 0 & 1250.65 \\
\hline 10130304 & 1383.489 & 0 & 6.12004 & 261266.7 & 0 & 343.08 \\
\hline 10130305 & 7834.371 & 0 & 618.844 & 403729.7 & 0 & 1663.21 \\
\hline 10130306 & 36375 & 2.880019 & 8079.533 & 655286 & 0 & 5360.79 \\
\hline 10140101 & 119140.6 & 34807.19 & 100141.5 & 929350.1 & 0 & 1860.85 \\
\hline 10140102 & 80739.53 & 30.2402 & 2996.66 & 738139.1 & 0 & 15287.86 \\
\hline 10140103 & 69104.61 & 2066.413 & 19635.97 & 105299.8 & 21254.36 & 272.52 \\
\hline 10140104 & 28590.67 & 77.0405 & 5484.996 & 144647.9 & 0 & 2780.3 \\
\hline 10140105 & 25186.84 & 3786.505 & 25376.2 & 286088.9 & 0 & 81 \\
\hline 10140201 & 13655.61 & 1.080007 & 756.3649 & 847436 & 0 & 6021.76 \\
\hline 10140202 & 21833.78 & 46.0803 & 795.9652 & 561312.1 & 0 & 4496.43 \\
\hline 10140203 & 18858.72 & 72.72047 & 3015.74 & 395875.5 & 0 & 5702.8 \\
\hline 10140204 & 51009.81 & 551.1636 & 18207.84 & 477081.6 & 0 & 3524.42 \\
\hline 10150001 & 5446.835 & 4845.272 & 14085.09 & 168546 & 0 & 14.4 \\
\hline 10150002 & 1211.048 & 0 & 2107.814 & 381806.2 & 0 & 1140.13 \\
\hline 10150003 & 44706.89 & 2.520016 & 34837.07 & 963699.6 & 0 & 25042.48 \\
\hline 10150004 & 920.166 & 2923.939 & 28859.23 & 945619.6 & 0 & 15.48 \\
\hline 10150005 & 87.12057 & 0 & 49.32032 & 222877.5 & 0 & 1.8 \\
\hline 10150006 & 1696.331 & 577.0838 & 10319.47 & 431910.3 & 0 & 36 \\
\hline 10150007 & 5840.318 & 13585.05 & 64715.1 & 295829.4 & 0 & 15.48 \\
\hline 10160001 & 113877 & 64527.9 & 38335.93 & 196181.7 & 35258.88 & 668.16 \\
\hline 10160002 & 41703.03 & 38009.05 & 20720.66 & 165603.8 & 0 & 391.68 \\
\hline 10160003 & 73366.68 & 255720.8 & 239772.4 & 680120.3 & 0 & 2078.29 \\
\hline 10160004 & 27207.54 & 63413.69 & 63871.98 & 361794.1 & 0 & 933.13 \\
\hline 10160005 & 18760.08 & 53718.83 & 59627.19 & 93001.63 & 0 & 51.84 \\
\hline 10160006 & 89412.34 & 164427.1 & 234003.7 & 815004.4 & 0 & 162.72 \\
\hline
\end{tabular}


TABLE E.2 (Cont.)

\begin{tabular}{|c|c|c|c|c|c|c|}
\hline Huc \# & $\begin{array}{c}\text { WHEAT_SUM } \\
\text { (ha) }\end{array}$ & $\begin{array}{c}\text { SOYB_SUM } \\
\text { (ha) }\end{array}$ & $\begin{array}{c}\text { CORN_SUM } \\
\text { (ha) }\end{array}$ & $\begin{array}{c}\text { Pasture Land Area } \\
\text { HAY/PAST/GRASS_SUM } \\
\text { (ha) }\end{array}$ & $\begin{array}{c}\text { Other } \\
\text { Agricultural } \\
\text { Land Area } \\
\text { (ha) }\end{array}$ & $\begin{array}{c}\text { Idle } \\
\text { Land/CRP } \\
\text { (ha) }\end{array}$ \\
\hline 10160007 & 32360.97 & 27253.98 & 51896.86 & 157521.6 & 0 & 37.8 \\
\hline 10160008 & 47909.83 & 59006.19 & 88330.17 & 354695.7 & 0 & 19.8 \\
\hline 10160009 & 67949.72 & 23087.67 & 55297.08 & 315321.2 & 0 & 58.32 \\
\hline 10160011 & 70124.14 & 180470.3 & 223481.9 & 874893.5 & 0 & 4.32 \\
\hline 10170101 & 27265.14 & 114406.6 & 189122.2 & 610552.2 & 0 & 8.28 \\
\hline 10170102 & 11809.16 & 149453.5 & 196443.9 & 342228.3 & 0 & 14.04 \\
\hline 10170103 & 3875.425 & 28187.82 & 32920.41 & 57465.51 & 0 & 7.56 \\
\hline 10170201 & 31250.9 & 52324.2 & 69151.7 & 194442.1 & 1326.2 & 56.52 \\
\hline 10170202 & 21616.6 & 107873 & 159822 & 202283.8 & 1141.9 & 655.56 \\
\hline 10170203 & 3480.48 & 213539 & 349096 & 214317.5 & 573.1 & 6.48 \\
\hline 10170204 & 649.8 & 130287 & 187404 & 67977.7 & 128.2 & 0.36 \\
\hline 10180001 & 0.36 & 0 & 0.36 & 56183.5 & & 0.36 \\
\hline 10180002 & 0 & 0 & 0 & 85965.9 & 136.4 & 0.36 \\
\hline 10180003 & 0.36 & 0 & 0 & 27569.8 & 11.5 & 1.44 \\
\hline 10180004 & 0 & 0 & 0 & 41997.0 & & 0 \\
\hline 10180005 & 0 & 0 & 0 & 26382.7 & & 0 \\
\hline 10180006 & 0.72 & 0 & 1.44 & 72122.8 & 49.3 & 23.04 \\
\hline 10180007 & 18.72 & 0 & 134.64 & 290602.1 & 704.9 & 152.28 \\
\hline 10180008 & 360 & 0 & 465.48 & 267779.2 & 1156.0 & 402.84 \\
\hline 10180009 & 32558.1 & 209.88 & 81836.7 & 1167134.1 & 26027.3 & 27404.29 \\
\hline 10180010 & 1.08 & 0 & 0 & 76159.9 & 2.2 & 4.68 \\
\hline 10180011 & 1406.88 & 0 & 6519.6 & 226577.5 & 1099.4 & 896.76 \\
\hline 10180012 & 4488.48 & 0 & 5591.16 & 393522.8 & 2219.0 & 5371.56 \\
\hline 10180013 & 6681.96 & 0 & 6471 & 247911.9 & 3182.8 & 2099.16 \\
\hline 10180014 & 11129.4 & 664.2 & 15959.9 & 529888.5 & 1694.2 & 9135.72 \\
\hline 10190001 & 4.32 & 0 & 0.72 & 268011.8 & 6.8 & 0.72 \\
\hline 10190002 & 90.72 & 0 & 13.32 & 70553.9 & 19.1 & 210.96 \\
\hline 10190003 & 54553.7 & 5.04 & 31173.1 & 527231.6 & 12673.4 & 62508.98 \\
\hline 10190004 & 14.4 & 0 & 5.76 & 33033.6 & 10.8 & 36.72 \\
\hline 10190005 & 5006.88 & 0 & 5056.2 & 71924.2 & 2800.4 & 2931.12 \\
\hline 10190006 & 3341.88 & 0 & 6082.2 & 48740.1 & 2267.6 & 3086.64 \\
\hline 10190007 & 3807.36 & 0 & 19023.8 & 192660.0 & 3501.4 & 2252.52 \\
\hline 10190008 & 1826.28 & 0.72 & 7148.16 & 139483.9 & 637.6 & 585.36 \\
\hline 10190009 & 3902.4 & 0.36 & 3178.8 & 351148.4 & 608.4 & 1124.64 \\
\hline 10190010 & 22711.7 & 2.16 & 1738.08 & 135289.1 & 2872.1 & 23044.33 \\
\hline 10190011 & 31039.2 & 0 & 4590 & 284086.9 & 3841.6 & 34804.45 \\
\hline 10190012 & 44937 & 105.12 & 41173.6 & 633171.1 & 12967.2 & 40185.38 \\
\hline 10190013 & 37235.9 & 1.44 & 4059 & 205310.2 & 4534.6 & 35423.65 \\
\hline 10190014 & 3412.08 & 5.04 & 3427.2 & 174124.9 & 1741.3 & 4732.2 \\
\hline
\end{tabular}


TABLE E.2 (Cont.)

\begin{tabular}{|c|c|c|c|c|c|c|}
\hline Huc \# & $\begin{array}{l}\text { WHEAT_SUM } \\
\text { (ha) }\end{array}$ & $\begin{array}{c}\text { SOYB_SUM } \\
\text { (ha) }\end{array}$ & $\begin{array}{c}\text { CORN_SUM } \\
\text { (ha) }\end{array}$ & $\begin{array}{c}\text { Pasture Land Area } \\
\text { HAY/PAST/GRASS_SUM } \\
\text { (ha) }\end{array}$ & $\begin{array}{c}\text { Other } \\
\text { Agricultural } \\
\text { Land Area } \\
\text { (ha) }\end{array}$ & $\begin{array}{c}\text { Idle } \\
\text { Land/CRP } \\
\text { (ha) }\end{array}$ \\
\hline 10190015 & 11211.5 & 0 & 1103.04 & 281191.4 & 2316.2 & 10424.88 \\
\hline 10190016 & 34563.6 & 6.84 & 12730.3 & 245212.1 & 8978.8 & 26276.05 \\
\hline 10190017 & 5570.64 & 0 & 1206.36 & 181823.1 & 1685.5 & 4472.64 \\
\hline 10190018 & 51823.1 & 3712.32 & 65687.1 & 182485.7 & 5113.1 & 36876.61 \\
\hline 10200101 & 7308 & 36421.6 & 224441 & 541817.3 & 2493.7 & 1542.24 \\
\hline 10200102 & 799.2 & 8113.68 & 60376.3 & 104099.8 & 821.2 & 114.48 \\
\hline 10200103 & 2291.04 & 23317.9 & 130749 & 98599.4 & 811.4 & 44.64 \\
\hline 10200201 & 821.52 & 41566.7 & 91026.8 & 63100.0 & 194.0 & 28.44 \\
\hline 10200202 & 613.44 & 30919.7 & 40100.4 & 30707.0 & 39.6 & 32.4 \\
\hline 10200203 & 5119.92 & 90426.6 & 97872.9 & 183899.9 & 432.0 & 28.8 \\
\hline 10210001 & 58.68 & 2.88 & 127.8 & 541178.9 & 64.1 & 8.64 \\
\hline 10210002 & 31.68 & 1.8 & 318.24 & 468790.4 & 428.0 & 5.04 \\
\hline 10210003 & 1149.84 & 9395.64 & 64716.5 & 386679.8 & 802.4 & 82.08 \\
\hline 10210004 & 3014.64 & 9782.28 & 60097.3 & 334141.3 & 1630.1 & 754.2 \\
\hline 10210005 & 1035 & 4834.44 & 35894.9 & 136505.9 & 579.2 & 146.88 \\
\hline 10210006 & 126.72 & 183.24 & 2566.44 & 605218.9 & 362.5 & 46.44 \\
\hline 10210007 & 956.16 & 6407.28 & 41479.2 & 187692.4 & 327.6 & 79.2 \\
\hline 10210008 & 6.48 & 296.28 & 1083.6 & 255237.2 & 127.4 & 3.96 \\
\hline 10210009 & 1975.68 & 40908.3 & 105152 & 217980.1 & 586.4 & 105.12 \\
\hline 10210010 & 713.88 & 12183.1 & 40966.9 & 264419.4 & 268.2 & 13.32 \\
\hline 10220001 & 2148.12 & 42191.7 & 111682 & 592258.9 & 889.2 & 51.84 \\
\hline 10220002 & 1141.56 & 42975 & 78549.9 & 72486.8 & 297.4 & 43.56 \\
\hline 10220003 & 2135.88 & 147244 & 208548 & 142403.2 & 579.6 & 84.6 \\
\hline 10220004 & 441.36 & 82207.5 & 116441 & 40488.8 & 336.2 & 9.72 \\
\hline 10230001 & 110.16 & 97312.4 & 146352 & 95962.5 & 758.2 & 5.76 \\
\hline 10230002 & 52.56 & 73974.3 & 108228 & 25410.2 & 58.3 & 0 \\
\hline 10230003 & 115.2 & 216608 & 289457 & 132426.3 & 280.8 & 0 \\
\hline 10230004 & 0.72 & 80541.4 & 109618 & 34535.9 & 39.6 & 0 \\
\hline 10230005 & 2.52 & 62377.2 & 82284.9 & 25288.2 & 53.3 & 0 \\
\hline 10230006 & 177.84 & 53452.5 & 72026.7 & 68464.7 & 148.7 & 68.4 \\
\hline 10230007 & 3.6 & 80159.1 & 123019 & 65167.3 & 157.7 & 0 \\
\hline 10240001 & 370.44 & 56818.5 & 63509.1 & 47279.7 & 41.8 & 403.2 \\
\hline 10240002 & 2.88 & 146718 & 179055 & 32306.4 & 132.1 & 0 \\
\hline 10240003 & 6.48 & 86314.7 & 108355 & 47606.1 & 132.5 & 1.44 \\
\hline 10240004 & 114.48 & 12036.6 & 16837.9 & 7220.3 & 24.5 & 0 \\
\hline 10240005 & 1202.04 & 118552 & 148308 & 83229.4 & 388.8 & 12.24 \\
\hline 10240006 & 3060.72 & 50482.8 & 57507.1 & 78060.9 & 92.5 & 82.44 \\
\hline 10240007 & 6513.84 & 20525 & 19932.8 & 99049.1 & 1079.6 & 93.96 \\
\hline 10240008 & 5274 & 54139.7 & 67806 & 125304.4 & 476.3 & 95.76 \\
\hline
\end{tabular}


TABLE E.2 (Cont.)

\begin{tabular}{|c|c|c|c|c|c|c|}
\hline Huc \# & $\begin{array}{l}\text { WHEAT_SUM } \\
\text { (ha) }\end{array}$ & $\begin{array}{c}\text { SOYB_SUM } \\
\text { (ha) }\end{array}$ & $\begin{array}{c}\text { CORN_SUM } \\
\text { (ha) }\end{array}$ & $\begin{array}{c}\text { Pasture Land Area } \\
\text { HAY/PAST/GRASS_SUM } \\
\text { (ha) }\end{array}$ & $\begin{array}{c}\text { Other } \\
\text { Agricultural } \\
\text { Land Area } \\
\text { (ha) }\end{array}$ & $\begin{array}{c}\text { Idle } \\
\text { Land/CRP } \\
\text { (ha) }\end{array}$ \\
\hline 10240009 & 3.96 & 40025.2 & 50974.2 & 87808.7 & 158.0 & 0 \\
\hline 10240010 & 38.88 & 49378.7 & 58313.5 & 99424.8 & 69.1 & 1.44 \\
\hline 10240011 & 1702.44 & 38760.5 & 40894.9 & 68435.7 & 268.6 & 18.36 \\
\hline 10240012 & 976.68 & 65179.5 & 68559.1 & 195345.7 & 249.1 & 1.44 \\
\hline 10240013 & 62.28 & 32083.6 & 35757.7 & 90394.2 & 39.2 & 0.36 \\
\hline 10250001 & 66473.3 & 299.16 & 33602.4 & 303040.2 & 14224.0 & 60727.7 \\
\hline 10250002 & 98981.7 & 899.28 & 100025 & 447207.3 & 36116.3 & 80464.71 \\
\hline 10250003 & 107983 & 324.36 & 50479.9 & 436385.7 & 16081.9 & 87478.95 \\
\hline 10250004 & 62406.7 & 3046.32 & 78954.1 & 350337.0 & 16951.7 & 46410.14 \\
\hline 10250005 & 61096 & 1022.76 & 95422.7 & 201654.8 & 21841.9 & 45577.46 \\
\hline 10250006 & 71319.3 & 1613.16 & 78930.4 & 166574.2 & 10220.8 & 45843.14 \\
\hline 10250007 & 13608 & 1411.92 & 35624.5 & 144451.1 & 2733.1 & 7706.88 \\
\hline 10250008 & 10368 & 3080.88 & 27273.3 & 190035.1 & 3796.6 & 5658.12 \\
\hline 10250009 & 22095.7 & 14754.2 & 71021.2 & 205051.9 & 6172.2 & 8289.72 \\
\hline 10250010 & 70796.2 & 690.12 & 43436.9 & 104124.6 & 16803.7 & 38910.97 \\
\hline 10250011 & 25299.4 & 599.76 & 21448.8 & 101803.0 & 6493.7 & 13529.89 \\
\hline 10250012 & 39353.4 & 62.64 & 35044.2 & 88213.4 & 6117.1 & 25853.05 \\
\hline 10250013 & 43821.7 & 170.28 & 27526 & 60016.7 & 5832.7 & 29239.57 \\
\hline 10250014 & 27541.5 & 621 & 17392.7 & 117261.0 & 10231.6 & 16630.21 \\
\hline 10250015 & 47932.2 & 1875.96 & 48901 & 132032.6 & 13835.5 & 27214.21 \\
\hline 10250016 & 44559.7 & 48059.3 & 98909.3 & 318411.8 & 12089.9 & 2215.44 \\
\hline 10250017 & 99668.9 & 39133.1 & 22603.3 & 256510.7 & 32243.1 & 1287 \\
\hline 10260001 & 33440.4 & 18.72 & 14256.4 & 187311.3 & 7660.1 & 29968.93 \\
\hline 10260002 & 33660.4 & 117.72 & 28852.6 & 94193.0 & 4825.4 & 27330.49 \\
\hline 10260003 & 58858.6 & 381.6 & 18059.8 & 236936.6 & 27008.7 & 41643.02 \\
\hline 10260004 & 82891.5 & 168.84 & 52829.3 & 154864.1 & 19404.4 & 56743.58 \\
\hline 10260005 & 36418.3 & 282.96 & 19248.8 & 73883.9 & 14482.8 & 23686.93 \\
\hline 10260006 & 77566 & 1368.72 & 1394.64 & 247968.6 & 28494.0 & 25954.93 \\
\hline 10260007 & 44817.1 & 330.12 & 11268 & 101019.7 & 22504.3 & 26885.53 \\
\hline 10260008 & 107240 & 17137.8 & 5184.72 & 337181.2 & 17030.5 & 453.6 \\
\hline 10260009 & 69100.6 & 1395.36 & 29675.9 & 329307.6 & 35135.7 & 33011.29 \\
\hline 10260010 & 61479.7 & 4231.08 & 618.48 & 261505.5 & 18355.7 & 6288.48 \\
\hline 10260011 & 56636.7 & 2469.96 & 48024 & 210630.0 & 18088.9 & 27599.77 \\
\hline 10260012 & 79309.5 & 6687.36 & 8111.52 & 185306.7 & 32911.9 & 16513.21 \\
\hline 10260013 & 43813.8 & 1632.6 & 32137.9 & 179708.5 & 18754.9 & 23600.17 \\
\hline 10260014 & 57004.9 & 3164.4 & 2481.84 & 177185.2 & 22756.7 & 12880.44 \\
\hline 10260015 & 145982 & 13385.2 & 3071.16 & 262348.1 & 33993.0 & 4757.04 \\
\hline 10270101 & 6433.56 & 4121.28 & 2046.6 & 98654.2 & 1490.0 & 10.44 \\
\hline 10270102 & 9049.32 & 33499.1 & 34855.2 & 383853.6 & 2256.8 & 14.04 \\
\hline
\end{tabular}


TABLE E.2 (Cont.)

\begin{tabular}{|c|c|c|c|c|c|c|}
\hline Huc \# & $\begin{array}{l}\text { WHEAT_SUM } \\
\text { (ha) }\end{array}$ & $\begin{array}{c}\text { SOYB_SUM } \\
\text { (ha) }\end{array}$ & $\begin{array}{c}\text { CORN_SUM } \\
\text { (ha) }\end{array}$ & $\begin{array}{c}\text { Pasture Land Area } \\
\text { HAY/PAST/GRASS_SUM } \\
\text { (ha) }\end{array}$ & $\begin{array}{c}\text { Other } \\
\text { Agricultural } \\
\text { Land Area } \\
\text { (ha) }\end{array}$ & $\begin{array}{c}\text { Idle } \\
\text { Land/CRP } \\
\text { (ha) }\end{array}$ \\
\hline 10270103 & 7059.24 & 33073.6 & 29651.8 & 150179.8 & 813.6 & 5.4 \\
\hline 10270104 & 9425.52 & 38169.7 & 33475.3 & 175393.7 & 899.3 & 45 \\
\hline 10270201 & 2144.16 & 67989.3 & 158938 & 30079.7 & 763.9 & 43.56 \\
\hline 10270202 & 12778.6 & 69221.5 & 87649.6 & 119771.0 & 2819.2 & 10.8 \\
\hline 10270203 & 6411.24 & 65993.1 & 190193 & 48975.1 & 1618.9 & 55.8 \\
\hline 10270204 & 6629.4 & 38877.1 & 70745.1 & 50860.9 & 3373.6 & 17.64 \\
\hline 10270205 & 34661.2 & 49105.8 & 31573.5 & 244729.6 & 10936.4 & 47.16 \\
\hline 10270206 & 34049.9 & 81000.8 & 229964 & 177206.9 & 7884.4 & 743.4 \\
\hline 10270207 & 34628.1 & 35835.9 & 31925.9 & 185333.9 & 14140.4 & 100.08 \\
\hline 10280101 & 3301.92 & 88812.4 & 63075.3 & 496424.5 & 586.1 & 3.6 \\
\hline 10280102 & 1037.52 & 57094.9 & 54576.4 & 304200.8 & 435.2 & 0.36 \\
\hline 10280103 & 6021.36 & 77145.9 & 34632 & 336458.9 & 171.4 & 11.52 \\
\hline 10280201 & 157.32 & 29099.2 & 27118.8 & 158604.2 & 153.7 & 3.24 \\
\hline 10280202 & 2475.72 & 29269.1 & 15088.7 & 113652.0 & 7.2 & 0.72 \\
\hline 10280203 & 2230.92 & 14990 & 10472.4 & 89965.9 & 113.0 & 2.52 \\
\hline 10290101 & 29278.5 & 65270.2 & 33329.2 & 319059.9 & 3338.3 & 34.92 \\
\hline 10290102 & 14699.5 & 43125.5 & 19568.5 & 212585.7 & 1312.9 & 136.08 \\
\hline 10290103 & 6019.56 & 12101.4 & 10338.8 & 78462.2 & 259.6 & 44.28 \\
\hline 10290104 & 11029.3 & 14205.6 & 13243 & 179935.1 & 695.5 & 14.76 \\
\hline 10290105 & 8475.84 & 9767.52 & 8588.16 & 117945.0 & 140.4 & 58.68 \\
\hline 10290106 & 3145.68 & 2900.52 & 3723.12 & 253837.2 & 103.0 & 4.32 \\
\hline 10290107 & 67.32 & 169.92 & 102.96 & 96813.8 & 6.1 & 10.08 \\
\hline 10290108 & 12124.1 & 42436.8 & 26026.9 & 292549.6 & 231.5 & 50.4 \\
\hline 10290109 & 317.88 & 528.84 & 512.64 & 82401.5 & 1.8 & 0.36 \\
\hline 10290110 & 6.12 & 9 & 65.52 & 82143.0 & 5.0 & 0 \\
\hline 10290111 & 426.6 & 1194.84 & 924.48 & 95119.6 & 43.6 & 0 \\
\hline 10290201 & 20.16 & 186.48 & 375.84 & 173500.6 & 9.4 & 3.6 \\
\hline 10290202 & 2.16 & 4.32 & 15.48 & 51951.3 & & 0 \\
\hline 10290203 & 238.32 & 1555.2 & 898.2 & 66883.7 & 22.0 & 0.36 \\
\hline 10300101 & 7429.68 & 106814 & 72821.5 & 238690.4 & 346.3 & 14.04 \\
\hline 10300102 & 11466.4 & 46517.1 & 43976.5 & 322245.1 & 1144.8 & 287.64 \\
\hline 10300103 & 7645.68 & 25116.1 & 20408.4 & 122642.7 & 127.8 & 11.16 \\
\hline 10300104 & 4543.56 & 64445.1 & 65991.3 & 135926.3 & 95.0 & 4.32 \\
\hline 10300200 & 2833.92 & 18058 & 19157 & 88254.8 & 478.8 & 22.68 \\
\hline
\end{tabular}


TABLE E.3 Fertilizer application rate.

\begin{tabular}{|c|c|c|c|}
\hline $\begin{array}{l}\text { Sub- } \\
\text { basin }\end{array}$ & Huc \# & $\begin{array}{c}\mathbf{N} \\
\text { Fertilizer } \\
\text { Input } \\
(\mathrm{kg} / \mathrm{Ha}) \\
\end{array}$ & $\begin{array}{c}\mathbf{P} \\
\text { Fertilizer } \\
\text { Input } \\
(\mathrm{kg} / \mathrm{Ha}) \\
\end{array}$ \\
\hline 1 & 10020001 & 0.83 & 0.23 \\
\hline 2 & 10020002 & 0.17 & 0.05 \\
\hline 3 & 10020003 & 0.62 & 0.18 \\
\hline 4 & 10020004 & 0.51 & 0.14 \\
\hline 5 & 10020005 & 0.28 & 0.08 \\
\hline 6 & 10020006 & 0.56 & 0.16 \\
\hline 7 & 10020007 & 1.87 & 0.55 \\
\hline 8 & 10020008 & 1.53 & 0.65 \\
\hline 9 & 10030101 & 0.25 & 0.07 \\
\hline 10 & 10030102 & 0.31 & 0.09 \\
\hline 11 & 10030103 & 1.73 & 0.50 \\
\hline 12 & 10030104 & 0.54 & 0.16 \\
\hline 13 & 10030105 & 3.54 & 1.03 \\
\hline 14 & 10030201 & 3.84 & 1.18 \\
\hline 15 & 10030202 & 0.57 & 0.18 \\
\hline 16 & 10030203 & 0.16 & 0.05 \\
\hline 17 & 10030204 & 0.50 & 0.16 \\
\hline 18 & 10030205 & 0.37 & 0.11 \\
\hline 19 & 10040101 & 0.40 & 0.11 \\
\hline 20 & 10040102 & 0.58 & 0.16 \\
\hline 21 & 10040103 & 0.22 & 0.06 \\
\hline 22 & 10040104 & 0.79 & 0.22 \\
\hline 23 & 10040105 & 0.22 & 0.06 \\
\hline 24 & 10040106 & 0.28 & 0.08 \\
\hline 25 & 10040201 & 0.15 & 0.04 \\
\hline 26 & 10040202 & 0.46 & 0.13 \\
\hline 27 & 10040203 & 2.54 & 0.71 \\
\hline 28 & 10040204 & 1.55 & 0.44 \\
\hline 29 & 10040205 & 0.86 & 0.24 \\
\hline 30 & 10050001 & 1.16 & 0.36 \\
\hline 31 & 10050002 & 0.11 & 0.03 \\
\hline 32 & 10050003 & 0.69 & 0.22 \\
\hline 33 & 10050004 & 0.16 & 0.05 \\
\hline 34 & 10050005 & 0.45 & 0.13 \\
\hline 35 & 10050006 & 0.44 & 0.14 \\
\hline 36 & 10050007 & 0.10 & 0.03 \\
\hline 37 & 10050008 & 0.18 & 0.05 \\
\hline 38 & 10050009 & 1.21 & 0.34 \\
\hline 39 & 10050010 & 0.37 & 0.10 \\
\hline
\end{tabular}


TABLE E.3 (Cont.)

\begin{tabular}{|c|c|c|c|}
\hline $\begin{array}{l}\text { Sub- } \\
\text { basin }\end{array}$ & Huc \# & $\begin{array}{c}\mathbf{N} \\
\text { Fertilizer } \\
\text { Input } \\
(\mathrm{kg} / \mathrm{Ha})\end{array}$ & $\begin{array}{c}\mathbf{P} \\
\text { Fertilizer } \\
\text { Input } \\
(\mathrm{kg} / \mathrm{Ha}) \\
\end{array}$ \\
\hline 40 & 10050011 & 0.11 & 0.03 \\
\hline 41 & 10050012 & 0.57 & 0.16 \\
\hline 42 & 10050013 & 0.09 & 0.03 \\
\hline 43 & 10050014 & 0.61 & 0.17 \\
\hline 44 & 10050015 & 1.28 & 0.35 \\
\hline 45 & 10050016 & 0.35 & 0.10 \\
\hline 46 & 10060001 & 0.18 & 0.05 \\
\hline 47 & 10060002 & 0.11 & 0.03 \\
\hline 48 & 10060003 & 0.04 & 0.01 \\
\hline 49 & 10060004 & 0.20 & 0.06 \\
\hline 50 & 10060005 & 4.76 & 2.30 \\
\hline 51 & 10060006 & 6.46 & 3.32 \\
\hline 52 & 10060007 & 9.10 & 4.63 \\
\hline 53 & 10070001 & 42.97 & 11.23 \\
\hline 54 & 10070002 & 0.63 & 0.22 \\
\hline 55 & 10070003 & 0.99 & 0.26 \\
\hline 56 & 10070004 & 0.50 & 0.14 \\
\hline 57 & 10070005 & 3.88 & 1.16 \\
\hline 58 & 10070006 & 0.47 & 0.17 \\
\hline 59 & 10070007 & 0.92 & 0.25 \\
\hline 60 & 10070008 & 2.68 & 0.73 \\
\hline 61 & 10080001 & 0.52 & 0.12 \\
\hline 62 & 10080002 & 0.61 & 0.13 \\
\hline 63 & 10080003 & 0.66 & 0.15 \\
\hline 64 & 10080004 & 1038.41 & 247.13 \\
\hline 65 & 10080005 & 0.64 & 0.14 \\
\hline 66 & 10080006 & 23.77 & 5.21 \\
\hline 67 & 10080007 & 0.24 & 0.06 \\
\hline 68 & 10080008 & 0.67 & 0.17 \\
\hline 69 & 10080009 & 0.17 & 0.05 \\
\hline 70 & 10080010 & 1.03 & 0.32 \\
\hline 71 & 10080011 & 1.94 & 0.51 \\
\hline 72 & 10080012 & 1.61 & 0.42 \\
\hline 73 & 10080013 & 0.27 & 0.07 \\
\hline 74 & 10080014 & 0.26 & 0.09 \\
\hline 75 & 10080015 & 0.38 & 0.10 \\
\hline 76 & 10080016 & 2.98 & 0.89 \\
\hline 77 & 10090101 & 1.56 & 0.43 \\
\hline 78 & 10090102 & 0.88 & 0.24 \\
\hline
\end{tabular}


TABLE E.3 (Cont.)

\begin{tabular}{rrrr}
$\begin{array}{r}\text { Sub- } \\
\text { basin }\end{array}$ & Huc \# & $\begin{array}{c}\text { N } \\
\text { Fertilizer } \\
\text { Input } \\
\text { (kg/Ha) }\end{array}$ & $\begin{array}{c}\text { Pertilizer } \\
\text { Input } \\
\text { (kg/Ha) }\end{array}$ \\
\hline & & & \\
79 & 10090201 & 0.83 & 0.18 \\
80 & 10090202 & 0.40 & 0.09 \\
81 & 10090203 & 21.89 & 4.72 \\
82 & 10090204 & 189.45 & 41.03 \\
83 & 10090205 & 0.68 & 0.15 \\
84 & 10090206 & 0.28 & 0.07 \\
85 & 10090207 & 1.51 & 0.38 \\
86 & 10090208 & 0.81 & 0.20 \\
87 & 10090209 & 1.20 & 0.33 \\
88 & 10090210 & 0.98 & 0.27 \\
89 & 10100001 & 0.15 & 0.04 \\
90 & 10100002 & 2.82 & 0.78 \\
91 & 10100003 & 2.79 & 0.78 \\
92 & 10100004 & 2.69 & 1.35 \\
93 & 10100005 & 0.70 & 0.19 \\
94 & 10110101 & 9.18 & 4.70 \\
95 & 10110102 & 11.78 & 5.98 \\
96 & 10110201 & 1.39 & 0.50 \\
97 & 10110202 & 1.06 & 0.43 \\
98 & 10110203 & 2.80 & 1.35 \\
99 & 10110204 & 2.81 & 1.38 \\
100 & 10110205 & 4.96 & 2.23 \\
101 & 10120101 & 20.59 & 4.54 \\
102 & 10120102 & 380.85 & 84.16 \\
103 & 10120103 & 0.16 & 0.04 \\
104 & 10120104 & 1.04 & 0.23 \\
105 & 10120105 & 4.06 & 0.89 \\
106 & 10120106 & 0.91 & 0.25 \\
107 & 10120107 & 0.18 & 0.06 \\
108 & 10120108 & 3.18 & 0.89 \\
109 & 10120109 & 0.59 & 0.23 \\
110 & 10120110 & 3.12 & 1.07 \\
111 & 10120111 & 1.17 & 0.54 \\
112 & 10120112 & 2.71 & 1.29 \\
113 & 10120113 & 1.30 & 0.63 \\
114 & 10120201 & 0.42 & 0.11 \\
\hline & 10120202 & 0.84 & 0.32 \\
\hline & 10130101 & 1.00 & 0.27 \\
\hline & & & 4.50 \\
\hline
\end{tabular}


TABLE E.3 (Cont.)

\begin{tabular}{|c|c|c|c|}
\hline $\begin{array}{l}\text { Sub- } \\
\text { basin }\end{array}$ & Huc \# & $\begin{array}{c}\mathbf{N} \\
\text { Fertilizer } \\
\text { Input } \\
(\mathrm{kg} / \mathrm{Ha})\end{array}$ & $\begin{array}{c}P \\
\text { Fertilizer } \\
\text { Input } \\
\text { (kg/Ha) }\end{array}$ \\
\hline 118 & 10130102 & 4.14 & 2.06 \\
\hline 119 & 10130103 & 5.21 & 2.88 \\
\hline 120 & 10130104 & 5.73 & 2.95 \\
\hline 121 & 10130105 & 8.84 & 4.50 \\
\hline 122 & 10130106 & 7.78 & 4.32 \\
\hline 123 & 10130201 & 5.25 & 2.56 \\
\hline 124 & 10130202 & 7.77 & 3.84 \\
\hline 125 & 10130203 & 8.38 & 3.92 \\
\hline 126 & 10130204 & 9.11 & 4.59 \\
\hline 127 & 10130205 & 5.61 & 2.81 \\
\hline 128 & 10130206 & 9.24 & 3.52 \\
\hline 129 & 10130301 & 4.13 & 2.01 \\
\hline 130 & 10130302 & 1.01 & 0.44 \\
\hline 131 & 10130303 & 2.91 & 1.40 \\
\hline 132 & 10130304 & 4.33 & 1.25 \\
\hline 133 & 10130305 & 2.04 & 0.82 \\
\hline 134 & 10130306 & 1.30 & 0.62 \\
\hline 135 & 10140101 & 7.92 & 4.52 \\
\hline 136 & 10140102 & 3.11 & 1.55 \\
\hline 137 & 10140103 & 13.88 & 6.76 \\
\hline 138 & 10140104 & 6.41 & 3.02 \\
\hline 139 & 10140105 & 9.21 & 4.91 \\
\hline 140 & 10140201 & 1.54 & 0.65 \\
\hline 141 & 10140202 & 2.01 & 0.92 \\
\hline 142 & 10140203 & 2.70 & 1.16 \\
\hline 143 & 10140204 & 5.11 & 2.40 \\
\hline 144 & 10150001 & 6.41 & 2.87 \\
\hline 145 & 10150002 & 4.32 & 1.17 \\
\hline 146 & 10150003 & 5.22 & 2.15 \\
\hline 147 & 10150004 & 8.12 & 2.47 \\
\hline 148 & 10150005 & 2.64 & 0.84 \\
\hline 149 & 10150006 & 5.20 & 1.97 \\
\hline 150 & 10150007 & 24.76 & 9.07 \\
\hline 151 & 10160001 & 13.22 & 8.88 \\
\hline 152 & 10160002 & 14.43 & 9.69 \\
\hline 153 & 10160003 & 15.40 & 10.15 \\
\hline 154 & 10160004 & 13.76 & 8.56 \\
\hline 155 & 10160005 & 15.54 & 9.56 \\
\hline 156 & 10160006 & 16.19 & 10.39 \\
\hline
\end{tabular}


TABLE E.3 (Cont.)

\begin{tabular}{rrrr}
\hline $\begin{array}{c}\text { Sub- } \\
\text { basin }\end{array}$ & Huc & $\begin{array}{c}\text { N } \\
\text { Fertilizer } \\
\text { Input } \\
\text { (kg/Ha) }\end{array}$ & $\begin{array}{c}\text { Fertilizer } \\
\text { Input } \\
\text { (kg/Ha) }\end{array}$ \\
\hline & & & \\
157 & 10160007 & 16.71 & 9.79 \\
158 & 10160008 & 14.79 & 9.07 \\
159 & 10160009 & 13.30 & 7.43 \\
160 & 10160011 & 15.47 & 10.43 \\
161 & 10170101 & 16.47 & 9.53 \\
162 & 10170102 & 21.01 & 14.06 \\
163 & 10170103 & 19.48 & 12.58 \\
1 & 10170201 & 27.3 & 14.4 \\
2 & 10170202 & 41.6 & 22.3 \\
3 & 10170203 & 51.5 & 28.2 \\
4 & 10170204 & 67.0 & 38.5 \\
5 & 10180001 & 0.0 & 0.0 \\
6 & 10180002 & 0.0 & 0.0 \\
7 & 10180003 & 0.0 & 0.0 \\
8 & 10180004 & 0.0 & 0.0 \\
9 & 10180005 & 0.0 & 0.0 \\
10 & 10180006 & 0.1 & 0.0 \\
11 & 10180007 & 0.1 & 0.0 \\
12 & 10180008 & 0.5 & 0.1 \\
13 & 10180009 & 9.8 & 3.0 \\
14 & 10180010 & 0.0 & 0.0 \\
15 & 10180011 & 2.5 & 0.7 \\
16 & 10180012 & 3.1 & 0.9 \\
17 & 10180013 & 5.3 & 1.7 \\
18 & 10180014 & 5.2 & 1.9 \\
19 & 10190001 & 0.2 & 0.0 \\
20 & 10190002 & 0.5 & 0.1 \\
21 & 10190003 & 9.0 & 3.0 \\
22 & 10190004 & 3.2 & 0.8 \\
23 & 10190005 & 6.9 & 1.9 \\
24 & 10190006 & 7.4 & 2.1 \\
25 & 10190007 & 7.0 & 1.9 \\
26 & 10190008 & 8.2 & 2.4 \\
27 & 10190009 & 1.8 & 0.6 \\
28 & 10190010 & 8.8 & 4.6 \\
29 & 10190011 & 9.3 & 4.3 \\
30 & 10190012 & 12.1 & 4.4 \\
31 & 10190013 & 10.6 & 5.2 \\
32 & 10190014 & 8.3 & 2.8 \\
\hline & & & \\
\hline
\end{tabular}


TABLE E.3 (Cont.)

\begin{tabular}{|c|c|c|c|}
\hline $\begin{array}{l}\text { Sub- } \\
\text { basin }\end{array}$ & Huc \# & $\begin{array}{c}\mathbf{N} \\
\text { Fertilizer } \\
\text { Input } \\
\text { (kg/Ha) }\end{array}$ & $\begin{array}{c}P \\
\text { Fertilizer } \\
\text { Input } \\
\text { (kg/Ha) }\end{array}$ \\
\hline 33 & 10190015 & 2.6 & 1.3 \\
\hline 34 & 10190016 & 10.4 & 4.4 \\
\hline 35 & 10190017 & 3.0 & 1.4 \\
\hline 36 & 10190018 & 33.1 & 12.4 \\
\hline 37 & 10200101 & 36.1 & 12.8 \\
\hline 38 & 10200102 & 49.5 & 16.4 \\
\hline 39 & 10200103 & 70.4 & 24.4 \\
\hline 40 & 10200201 & 61.2 & 25.8 \\
\hline 41 & 10200202 & 46.2 & 23.0 \\
\hline 42 & 10200203 & 37.7 & 19.4 \\
\hline 43 & 10210001 & 0.6 & 0.2 \\
\hline 44 & 10210002 & 0.2 & 0.1 \\
\hline 45 & 10210003 & 22.3 & 7.4 \\
\hline 46 & 10210004 & 21.7 & 7.5 \\
\hline 47 & 10210005 & 32.0 & 10.6 \\
\hline 48 & 10210006 & 0.8 & 0.3 \\
\hline 49 & 10210007 & 23.3 & 11.1 \\
\hline 50 & 10210008 & 0.9 & 0.5 \\
\hline 51 & 10210009 & 42.4 & 24.9 \\
\hline 52 & 10210010 & 20.8 & 11.0 \\
\hline 53 & 10220001 & 22.3 & 13.7 \\
\hline 54 & 10220002 & 50.6 & 30.0 \\
\hline 55 & 10220003 & 59.6 & 40.3 \\
\hline 56 & 10220004 & 63.5 & 40.8 \\
\hline 57 & 10230001 & 48.1 & 31.0 \\
\hline 58 & 10230002 & 65.3 & 41.8 \\
\hline 59 & 10230003 & 55.5 & 32.2 \\
\hline 60 & 10230004 & 49.2 & 24.0 \\
\hline 61 & 10230005 & 57.8 & 39.1 \\
\hline 62 & 10230006 & 35.7 & 22.1 \\
\hline 63 & 10230007 & 51.7 & 23.9 \\
\hline 64 & 10240001 & 42.3 & 23.6 \\
\hline 65 & 10240002 & 56.9 & 31.4 \\
\hline 66 & 10240003 & 46.7 & 26.2 \\
\hline 67 & 10240004 & 48.8 & 26.1 \\
\hline 68 & 10240005 & 44.6 & 24.8 \\
\hline 69 & 10240006 & 38.4 & 20.9 \\
\hline 70 & 10240007 & 17.8 & 9.9 \\
\hline 71 & 10240008 & 33.6 & 17.3 \\
\hline
\end{tabular}


TABLE E.3 (Cont.)

\begin{tabular}{|c|c|c|c|}
\hline $\begin{array}{l}\text { Sub- } \\
\text { basin }\end{array}$ & Huc \# & $\begin{array}{c}\mathbf{N} \\
\text { Fertilizer } \\
\text { Input } \\
\text { (kg/Ha) }\end{array}$ & $\begin{array}{c}P \\
\text { Fertilizer } \\
\text { Input } \\
\text { (kg/Ha) }\end{array}$ \\
\hline 72 & 10240009 & 32.6 & 16.9 \\
\hline 73 & 10240010 & 32.7 & 17.9 \\
\hline 74 & 10240011 & 22.3 & 16.1 \\
\hline 75 & 10240012 & 0.0 & 0.0 \\
\hline 76 & 10240013 & 0.1 & 0.0 \\
\hline 77 & 10250001 & 13.4 & 4.6 \\
\hline 78 & 10250002 & 11.6 & 4.0 \\
\hline 79 & 10250003 & 11.6 & 4.4 \\
\hline 80 & 10250004 & 15.2 & 5.0 \\
\hline 81 & 10250005 & 33.2 & 10.5 \\
\hline 82 & 10250006 & 22.6 & 7.6 \\
\hline 83 & 10250007 & 27.3 & 11.2 \\
\hline 84 & 10250008 & 16.1 & 5.9 \\
\hline 85 & 10250009 & 24.2 & 9.9 \\
\hline 86 & 10250010 & 40.8 & 17.1 \\
\hline 87 & 10250011 & 29.9 & 13.6 \\
\hline 88 & 10250012 & 40.3 & 18.3 \\
\hline 89 & 10250013 & 33.3 & 12.4 \\
\hline 90 & 10250014 & 24.9 & 9.3 \\
\hline 91 & 10250015 & 31.5 & 11.2 \\
\hline 92 & 10250016 & 28.0 & 15.0 \\
\hline 93 & 10250017 & 17.9 & 12.0 \\
\hline 94 & 10260001 & 14.0 & 5.6 \\
\hline 95 & 10260002 & 30.7 & 11.0 \\
\hline 96 & 10260003 & 15.7 & 7.3 \\
\hline 97 & 10260004 & 31.1 & 12.4 \\
\hline 98 & 10260005 & 30.3 & 12.4 \\
\hline 99 & 10260006 & 12.5 & 6.7 \\
\hline 100 & 10260007 & 15.0 & 6.6 \\
\hline 101 & 10260008 & 11.7 & 7.7 \\
\hline 102 & 10260009 & 14.6 & 6.2 \\
\hline 103 & 10260010 & 9.3 & 5.3 \\
\hline 104 & 10260011 & 22.6 & 8.9 \\
\hline 105 & 10260012 & 16.7 & 8.9 \\
\hline 106 & 10260013 & 21.7 & 8.6 \\
\hline 107 & 10260014 & 15.1 & 7.9 \\
\hline 108 & 10260015 & 17.3 & 10.3 \\
\hline 109 & 10270101 & 5.6 & 3.4 \\
\hline 110 & 10270102 & 9.0 & 5.6 \\
\hline
\end{tabular}


TABLE E.3 (Cont.)

\begin{tabular}{|c|c|c|c|}
\hline $\begin{array}{l}\text { Sub- } \\
\text { basin }\end{array}$ & Huc \# & $\begin{array}{c}\mathbf{N} \\
\text { Fertilizer } \\
\text { Input } \\
(\mathrm{kg} / \mathrm{Ha})\end{array}$ & $\begin{array}{c}P \\
\text { Fertilizer } \\
\text { Input } \\
\text { (kg/Ha) }\end{array}$ \\
\hline 111 & 10270103 & 15.5 & 9.6 \\
\hline 112 & 10270104 & 13.1 & 8.8 \\
\hline 113 & 10270201 & 68.8 & 31.0 \\
\hline 114 & 10270202 & 38.1 & 20.3 \\
\hline 115 & 10270203 & 71.7 & 28.7 \\
\hline 116 & 10270204 & 51.3 & 24.0 \\
\hline 117 & 10270205 & 15.0 & 10.2 \\
\hline 118 & 10270206 & 51.1 & 21.8 \\
\hline 119 & 10270207 & 18.4 & 11.0 \\
\hline 120 & 10280101 & 11.1 & 7.6 \\
\hline 121 & 10280102 & 14.1 & 10.5 \\
\hline 122 & 10280103 & 10.1 & 10.2 \\
\hline 123 & 10280201 & 12.0 & 8.7 \\
\hline 124 & 10280202 & 11.3 & 9.2 \\
\hline 125 & 10280203 & 11.4 & 8.2 \\
\hline 126 & 10290101 & 10.4 & 6.6 \\
\hline 127 & 10290102 & 9.2 & 6.4 \\
\hline 128 & 10290103 & 11.6 & 6.4 \\
\hline 129 & 10290104 & 9.0 & 4.7 \\
\hline 130 & 10290105 & 6.5 & 3.9 \\
\hline 131 & 10290106 & 2.2 & 1.0 \\
\hline 132 & 10290107 & 1.2 & 0.3 \\
\hline 133 & 10290108 & 9.4 & 6.6 \\
\hline 134 & 10290109 & 0.8 & 0.3 \\
\hline 135 & 10290110 & 1.0 & 0.3 \\
\hline 136 & 10290111 & 2.9 & 1.2 \\
\hline 137 & 10290201 & 1.3 & 0.3 \\
\hline 138 & 10290202 & 1.2 & 0.3 \\
\hline 139 & 10290203 & 1.2 & 0.6 \\
\hline 140 & 10300101 & 19.3 & 13.2 \\
\hline 141 & 10300102 & 9.0 & 5.7 \\
\hline 142 & 10300103 & 14.9 & 9.5 \\
\hline 143 & 10300104 & 29.7 & 18.3 \\
\hline 144 & 10300200 & 7.8 & 4.7 \\
\hline
\end{tabular}





\section{Argonne}

\section{Energy Systems Division}

Argonne National Laboratory

9700 South Cass Avenue, Bldg. 362

Argonne, IL 60439-4815

www.anl.gov 